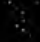

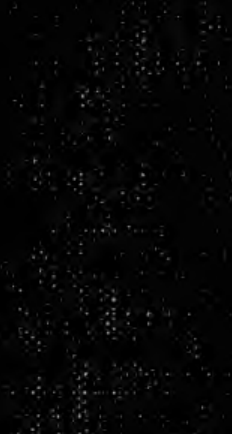

1. 440

$\therefore \therefore$ 

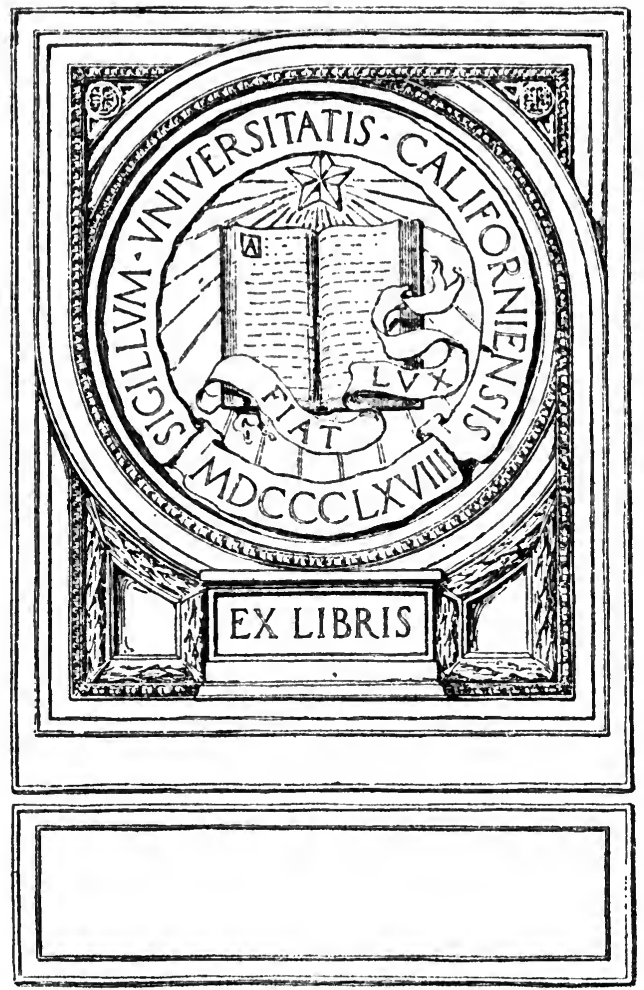
Feel y the

Endure

Fan bun ce 



\section{PRESENT PROBLEMS IN FOREIGN POLICY}




\section{Books By David Jayne Hill}

A History of Diplomacy in the International Development of Europe.

Vol. I.-The Struggle for Universal Empire. With 5 Colored Maps, Chronological Tables, List of Treaties and Index. P . XXII$48 \mathrm{r}$.

Vol. II.-The Establishment of Territorial Sovereignty. With 4 Colored Maps, Tables, etc. $P p . X X I V-688$.

Vol. III.-The Diplomacy of the Age of Absolutism. With 5 Colored Maps, Tables, etc. Pp. $X X V I-706$.

World Organization, as Affected by the Nature of the Modern State. $P p . I X-2 I 4$. Translated also into French and German.

The People's Government.

Pp. $X-288$.

Americanism-What It Is.

$P p: X V-283$.

Translated also into French.

The Rebuilding of Europe.

$P$ p. XII-289.

Translated also into French.

Impressions of the Kaiser.

Pp. $X I I-266$.

Present Problems in Foreign Policy. 


\title{
PRESENT PROBLEMS IN FOREIGN POLICY
}

\author{
BY
}

DAVID JAYNE HILL $\triangle O T H O R$ OF "THE PEOPLE'B GOVERNMENT,"

"ammricanisu-What IT Is," exc.

\section{APPLETON AND COMPANY NEW YORK AND LONDON MCMXIX}




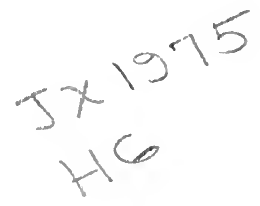

Copyright, 1919, BY

D. APPLETON AND COMPANY

Copyright, 1919, by

The North American Review Publighina Ca

PBINTED IN THE UNITED STATES OF AMERICA 
"Europe has a set of primary interests zohich to us have no, or a very remote, relation. Hence she must be engaged in frequent controversies, the causes of which are essentially foreign to our concerns. Hence therefore it must be unvise in us to implicate ourselves, by artificial ties, in the ordinary vicissitudes of her politics, or the ordinary combinations and collisions of her friendships or enmities. It is our true policy to steer clear of permanent alliances with any portion of the foreign world-so far, I mean, as we are now at liberty to do it; for let me not be understood as capable of patronizing infidelity to existing engagements."

George Washington. 
Digitized by the Internet Archive in 2007 with funding from Microsoft Corporation 


\section{PREFACE}

The Great War has been on the part of the Entente Allies avowedly a battle against autocracy. The occasion for it was that autocracy, having no basis in principles of justice, ruled by the exercise of arbitrary force regardless of the restraints of law.

The conflict ended in the triumph of democracy. The autocratic empires were left in ruins. The task of democracy is to reorganize the emancipated populations and to create responsible governments which can maintain legal relations: with one another.

This can be done only by the firm establishment of law, both national and international; for democracy without respect for law is anarchy. Having no unity of interest or constancy of purpose, a lawless democracy implies a perpetual conflict without definite aims, in which all the participants waste their energies in mutual resistance.

If, therefore, democracy is to survive and organize its victory, it must do so in a spirit of loyalty to principles of justice. The will of 


\section{PREFACE}

the victor must be guided by the spirit of obedience to law. Its first necessity, however, is to prove that law cannot be violated with impunity.

The fundamental problem that confronts us at the termination of the Great War is, therefore, the restoration of the rule of law. I say the restoration, and not the inauguration, of the rule of law, because the idea of law is not a new idea, and a nominal respect for law is not a new state of mind. The defect in pre-war international organization was not that International Law did not exist or that it was not in theory authoritative, but that there was no fixed determination on the part of any nation to enforce it except in its own interest.

The lesson of the war is that the enforcement of International Law is a universal and not merely a national interest; and that, in reality, there is no human interest that is comparable with it in importance except the enforcement of just laws within the nations themselves.

The difference between the ante-war period and that upon which we have entered lies chiefly in this: that before the war nations were to a great extent ruled by autocratic masters who had no regard for law but were guided by their own ambitions and the ambitions of those who supported them; whereas the dissolution of these imperial Powers has left their populations free to 


\section{PREFACE}

reëstablish themselves upon lines of organized liberty under law.

The task of accomplishing this is a stupendous one. Without mutual aid, and especially without the utter extermination of the spirit of military autocracy, it is impossible. The first step in the accomplishment of that task is peace,-a peace in which it is made clear to all the world that the spirit which caused the war is completely subdued and rendered powerless for further disturbance. Such a peace must be a peace of victory, in which it is made evident that law has been vindicated, and that violations of it can be and are effectively punished. To speak of peace in any other sense than this before such a peace is imposed is to substitute dreams for realities. Herein lies the test of what the future of the world will be.

When that condition of peace is fulfilled, when it is plainly established that the violation of In:-ernational Law can really be punished, there will be a ground for faith that it can in the future be maintained. With the certainty of justice will come the organization of peace, and it can be attained in no other way.

The object of this little book is to maintain the thesis that without the rule of law there is no hope of permanent peace; and that International Law, being the affair of all nations, requires for its 


\section{PREFACE}

enforcement that all nations, and not a single group organized in their own interest, shall freely have a part in the formulation and protection of it.

The proper task of the Entente of Free Nations formed in the prosecution of the Great War is not, therefore, to create a mere organ of power but an institution of justice. Such an institution cannot be established by a League of Nations, unless as an organization it makes law and not power the chief object of its existence. If it dedicates its energies frankly to the perfection of International Law, it may indeed rise to the height of world leadership; but, because all sovereign States are equal before the law, it cannot long subsist merely as a "League," which is essentially a group of Powers within the general Society of States. What is required is the union, not the division, of that society. Working as an Entente of Free Nations toward the ultimate establishment of that society on the basis of a common law, the victors in the war have had their opportunity to prove that violations of law, even of great magnitude, can be punished, and that the time has come, in the light of that result, for the whole Society of States to unite in the perfection and the protection of the Law of Nations.

This is not the course that has been pursued in the Peace Conference at Paris. "The Constitution 


\section{PREFACE}

of a League of Nations" elaborated there has been formed under the stress of an unfinished war, in the face of an unrepentant foe, in the midst of conflicting national interests, and under intimidation by the presence of a wholly new enemy tending to destroy all responsible government. It is the work not of jurists building on solid foundations already laid, but of politicians holding a brief for particular interests or a personal theory.

These conditions have prevented the dispassionate consideration of the fundamental problem of permanent international organization on the basis of International Law, for which no provision is made. The "League of Nations," although contemplating the preservation of peace by the creation of a defensive alliance and an imperial syndicate for the regulation of the world under the control of a small group of Great Powers, is nowhere pledged to the maintenance of International Law or to the recognition of the inherent rights of States. It provides for war, and lays down conditions on which it will be resorted to; but it does not provide for justice through the perfection and enforcement of law based upon agreement.

What was needed to give effect to the work of the Hague Conferences was its further extension and a provision for applying and enforcing its results. The proposed League of Nations wholly disregards historic continuity, makes no reference 


\section{PREFACE}

to past achievements or provision for completing them, and simply takes us back to the conception of the preponderance of power.

That which especially justifies these reflections is that the League of Nations, as it has been framed, does not correspond to our American traditions and ideals. On the contrary, it is in some respects an abandonment of them. How far this is true the reader may judge for himself. The aim of the writer has been, without prejudice, but with perfect freedom, to discuss the problems which the "League" raises as well as those which it attempts to solve. And this, it is believed, can be done the more freely because the idea of a "League," although with some evident misapprehensions, has been received in Europe as an American idea.

The author is indebted to "The North American Review" for permission to use some of the papers which first appeared in that periodical.

The fourth and fifth chapters are in substance two lectures delivered before the George Washington University.

David J AYne Hill. 


\section{CONTENTS}

PAGE

Preface . . . . . . . . . . . . . vin

I. The Entente of Free Nations . . . . . 1

II. Germany's Pose for Peace • • . . . 38

'III. International LaW and Policy • • . • . 69

IV. The Corporate Character of the League of Nations . . . . . . . . . . . 104

V. The Treaty-Making Power Under the Constitution of the United States . . . . . 140

VI. The Obstruction of Peace - . . . . . 180

VII. The Débâcle of Dogmatism . . . . . . 225.

VIII. The President's Challenge to the Senatr • 263

\section{DOCUMENTS}

-I. President Wilson's "Points" . . . . . . 303

II. The Covenant as Originally Agreed Upon at .

PARIS . . . . . . . . . . . . 309

III. The Senate "Round Robin" • . . . . . 325

IV. Amendments Proposed . . . . . . . . 327

V. The Covenant as Revised . . . . . . . . 334

INDEX • • . • • • • • • . . • . 355 



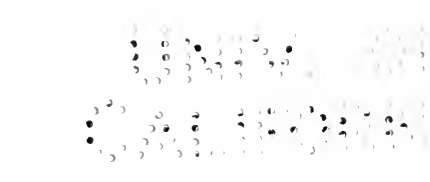

$\mathbf{I}$

THE ENTENTE OF FREE NATIONS

IN every period of warfare since modern nations came into existence, there have been serious reflections upon the cost and the horrors of war which have culminated in schemes for preventing it altogether. Some of these have been merely abstract theories regarding the manner in which international conflicts could be obviated or rendered impossible; while others have been of a more pragmatic character, aiming to create in the realm of actuality a situation which would safeguard the interests of peace and possibly of justice.

The Thirty Years' War, which was ended by the Peace of Westphalia, in 1648, suggested to Emeric Crucé his "Nouveau Cynée," written during its progress in 1623, in which the Republic of Venice was proposed as a place where a permanent corps 


\section{PROBBiEMS IN FOREIGN POLICY}

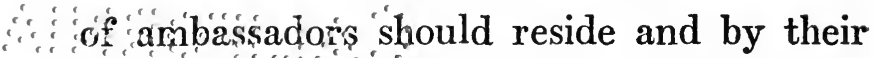
votes settle all international disputes. In 1625 Hugo Grotius, perceiving that such settlements could not be made except upon some basis of previously accepted rules and principles, gave to the world his great work, "De Jure Belli ac Pacis," the first complete treatise on the Law of Nations; and to this he added the proposal of "some kind of a body in whose assemblies the quarrels of each one might be terminated by the judgment of others not interested," and that "means be sought to constrain the parties to agree to reasonable conditions."

In like manner, in 1634, a notable device for maintaining peace, called the "Great Design," was invented by the Duke of Sully and attributed to Henry IV of France as the plan of that monarch for ending the long struggle between the House of Hapsburg and the rest of Europe; but it is now established that it was the scheme of Sully himself, who as a fallen minister hoped by this means to procure his own recall to the administration of the affairs of his country. All 


\section{THE ENTENTE OF FREE NATIONS}

Europe, according to this plan, was to be organized into fifteen States, which should together constitute one Christian Republic, in which wars were to be prevented by a General Council, composed of forty delegates, meeting annually in the most central cities of the different countries in rotation.

During the Congress of Utrecht, in 1713, the Abbé de St. Pierre elaborated his "Project of Perpetual Peace," to which more particular reference will be made in discussing the provisions of the League of Nations proposed at Paris, of which it is an almost perfect prototype. The Napoleonic Wars also brought forth plans for international peace, the most conspicuous effort being that of Immanuel Kant, in 1796, in his essay on "Eternal Peace," in which the solution offered by this Prussian philosopher was that all States should become republican in form; a condition, as he thought, which would enable them by some kind of general federation to unite their forces for the preservation of peace.

It is not surprising, therefore, that, as a 3 


\section{PROBLEMS IN FOREIGN POLICY}

result of the defeat of the aggressors in the Great War now, as we hope, happily terminated by the united efforts of a group of advanced and liberal nations, these plans, or modifications of them, should again receive attention, and that a general desire should be created for "some kind of body," as Grotius expressed the aspiration, which could prevent the repetition of the experience through which the world has passed.

What was impossible before the Great War, it is believed by many, could be easily accomplished now; and that, therefore, even before a peace is finally concluded, and as an essential part of it and a condition of its perpetuity, a "League of Nations" should be formed.

There are, it is true, wide differences of opinion regarding the objects, the methods, the organization, and the obligations of such a league, varying from the creation of a World State by the federation of the existing nations into one vast political organism including all, both small and great, to a limited compact confined to a few Powers 


\section{THE ENTENTE OF FREE NATIONS}

with no function beyond the peaceable adjudication of differences by an international tribunal without power to enforce its judgments.

The occasion is, no doubt, opportune for a thorough discussion of these widely differing plans, and it is timely for their advocates to express their views and support their conceptions by argument; but it is by no means to be taken for granted that any one of these projects, however honestly and earnestly its supporters may believe it should be at once adopted, is either practicable or desirable. The stress of insistence should not be placed upon the means of forcing the acceptance of a particular plan, however meritorious it may be in itself, but upon the intelligent comparison of different plans and a patient examination of their probable effects.'

That which needs, first of all, to be emphasized is, that no one Power can expect, or should desire, to impose upon others a system which they do not all heartily approve; and, in the next place, that if any plan is to 


\section{PROBLEMS IN FOREIGN POLICY}

be permanent and effective, it must have the support not only of the leading governments but of the great masses of the people whom those governments represent. It is, therefore, greatly to be desired that the public should be fully informed before any decisive step is taken, that nothing should be urged until it is well understood, and that no theorist, however competent and trusted, should be regarded as a trustee of a whole people in a matter of such import and consequence. The true principle that should be involked for guidance in this matter was well and forcibly enunciated by the President of the United States when, in 1912, in his first electoral campaign, he dwelt upon the value of "common counsel," and, as one of the people, seeking leadership, expressed his attitude regarding public policies in the words: "I am one of those who absolutely reject the trustee theory, the guardianship theory. I have never found a man who knew how to take care of me, and, reasoning from that point out, I conjecture that tkere isn't any man who knows how to take care of all the 


\section{THE ENTENTE OF FREE NATIONS}

people of the United States. I suspect that the people of the United States understand their own interests better than any group of men in the confines of the country understand them."

It may, of course, be thought that it is not the "interests of the people of the United States" that should prevail in the formation of an organization so general as a "League of Nations," but the interests of humanity. This may be true, but the "trustee theory, the guardianship theory," is perhaps even less applicable to humanity as a whole than it is to a single people, who in ordinary circumstances may at least have an opportunity to choose, and to some extent direct, their trustee or guardian.

It would, however, be a fatal error to overlook the fact that the interests of the people of the United States, as well as the interests of other portions of humanity, are deeply involved in any plan to form a "League of Nations." Great benefits might accrue, or serious disadvantages might result from occupying a place in it. It is the 


\section{PROBLEMS IN FOREIGN POLICY}

duty of the people as well as the statesmen of the nations that may enter into such a league, to consider for themselves the alleged benefits and the possible disadvantages. This has been done in Great Britain, in France, in Italy, and in Japan,-to mention only a few of the co-belligerents,-and their interests, which are different, have been carefully considered. The signs of this are evident to those who are familiar with the contemporary comments of the European press upon this subject, especially the great British quarterlies, which have discussed the "League of Nations" with a candor, a seriousness, and an understanding that have not been equaled by American periodicals of the same class, which have inclined to take the complimentary speeches of Lloyd George, Lord Grey, Mr. Asquith, and Mr. Balfour as a complete and authoritative expression of British opinion, but this is far from being the case.

No discussion of the subject had been published in America to compare in amplitude of knowledge and solidity of judgment with 


\section{THE ENTENTE OF FREE NATIONS}

the treatment of it under the title "The Greatest League of Nations," by Lord Sydenham of Combe, in "The Nineteenth Century and After," for August, 1918, which concludes: "We shall not win the war by planning Leagues of Peace to meet circumstances which we cannot yet foresee. Like the paper constitutions of Siéyès they may prove impracticable; but the Holy Alliance against the forces of evil remains, and when it is crowned with victory it can be turned into a powerful agency for maintaining the peace of the world. Then, in some happier future, the vision of Isaiah may be fulfilled, and 'Nation shall not lift up sword against nation; neither shall they learn war any more." "

Nor had anything appeared in the American periodicals so searching and so well informed as the article by J. B. Firth, under the title "The Government and the League of Nations," in "The Fortnightly Review" for September, 1918. He points out that the British Government some months before appointed "a very well chosen Committee," 


\section{PROBLEMS IN FOREIGN POLICY}

-as Mr. Balfour described it,_-"on which international law and history were powerfully represented," to examine and report on a "League of Nations." "The report," he says, "has been drawn up, but its contents have not been divulged. Neither Lord Curzon nor Mr. Balfour alluded to it; they did not even say that it had been considered by the War Cabinet. By a curious coincidence the same official reticence is being observed in France. There, too, an authoritative Commission, presided over by M. Bourgeois, was appointed by the Government, and issued its report last January; but it has not been published in France, and, according to Lord Curzon, no copy of it had reached the British Government on June 26th. Why this secretiveness, both in London and Paris? If there had been practical unanimity in favor of the project there could be no reason for reserve."

There was, no doubt, however, an excellent reason for this discreet silence. It is the desire of the officials of both England and France not to wound the sensibilities of the 


\section{THE ENTENTE OF FREE NATIONS}

Americans, who are credited with being the sponsors of the "League of Nations." The British leaders, always without definition, but in a fine spirit of courtesy, took up the watchword, a "League of Nations,"-for it was so far nothing more,-and Lord Curzon was able to say in the House of Lords, that opinion in England in favor of the League was "rather in advance of the opinion of any of our Allies save the United States"; and he added, that "if the British Government went ahead too quickly, or too abruptly, there was danger of a rebuff." As a confirmation of this danger, Mr. Firth remarks, that, "although the report of the French Commission has not been published, it is an open secret that its judgment was adverse to any proposal for establishing an international force which shall be always ready to enforce the decisions of the League upon a recalcitrant member."

In an admirable historic summary, Mr. Firth illustrates with instances the tedious wrangling in the so-called Concert of Europe over the simplest and most necessary forms 


\section{PROBLEMS IN FOREIGN POLICY}

of coöperative action, and asks: "How can these idealists talk airily about the establishment of an international army or the dispatch of an international expedition to deal with an aggressor against the 'League of Nations,' when they see how long it has taken Japan and the United States to come to an understanding on the subject of joint action in Siberia? Every hour was of priceless value ... Yet days and weeks were suffered to slip by for political reasons which are perfectly well known and thoroughly understood. Will it be any different when there is a 'League of Nations'?'

A passage as instructive to Americans as it is characteristic of English thought is found in the "English Review" for October, 1918, in which its editor, Austin Harrison, illustrates what he conceives to be a general principle by what he regards as a conspicuous example. "There is and can be no such thing," he says, "as democratic government, as loosely understood; for every democracy is controlled by an oligarchy, whether of intellect, of interest, or of mere popularity, 


\section{THE ENTENTE OF FREE NATIONS}

and the purer the democracy the greater would seem to be the authority of its oligarchy, as we have all seen in the astonishing singleness, discipline, and elasticity of the heterogeneous masses of America at war under what is nothing less than the sovereign will of the President. It is this acceptance of oligarchical authority in America that differentiates the democracy of the New World from that of the Old, as particularly exemplified in Britain. Take the case of conscription, which in America became law overnight, though three thousand miles of sea divided America from the theater of the war, and in no case was any motive put forward for war but that of principle. Here it took us two years, because our democracy does not accept its oligarchy, does not recognize acquiescence, is intellectually and traditionally antagonized by the very idea of authority, whether of government or opportunity."

It is true that the people of the United States have been singularly united and singularly obedient to leadership, but the com- 


\section{PROBLEMS IN FOREIGN POLICY}

ment fails to find a true interpretation of the fact. This nation has never bowed to "the sovereign will of the President." It has respected the voice of individual conscience. It beheld in the conduct of Germany an inexpressible wrong of gigantic proportions. It shuddered, but it did not hesitate to judge or condemn. Millions, tens of millions, of men in America wanted to fight Germany when the will of the President was not yet for war, and chafed under the neutrality of their Government. Thousands of our young men went to Canada and to France, in order to help in defeating Germany before any "sovereign will" had expressed itself in the United States. There is the explanation of conscription. It was, indeed, based on a "principle"; but the principle was not a governmental enunciation, it was a deep-seated and almost universal declaration of the national mind.

It took England, Mr. Harrison says, "two years to adopt conscription, because English democracy does not accept its oligarchy." In the result the advantage is with England. 


\section{THE ENTENTE OF FREE NATIONS}

It took us much more than two years to prepare for war, because our oligarchy did not appeal to its democracy.

The error of this brilliant writer regarding our "oligarchy" and its influence has led him more seriously astray on some other points. Without our intervention, he thinks, the Great War would have had to be settled on the principle of "the balance of power,"-a peace without a victory; and from this he argues that "the message of America is democracy, her mission is union." America is thus held responsible for proposing a "League of Nations." We have been fighting, he thinks, "not Germany; not, in the historical sense, the Germans; but the German idea of mastery, the German feudal system, the Kultur of imperial and dynastic ambition. America is thus fighting against the attitude of the balance of power."

This is a total misapprehension, which proves how inadequately British perception has comprehended our real motives as a people, and how insufficiently we have thus far expressed them. It assumes that we have 


\section{PROBLEMS IN FOREIGN POLICY}

been fighting for "fourteen points" of European and world reconstruction; and that the success of those, including a "League of Nations," was what we have had in mind. There is probably not one soldier or even one officer in the American Army, either in the field or at home, who ever thought for a moment that he, or his country, was carrying on this war "against the attitude of the balance of power," or to establish a "League of Nations." Not one in a hundred thousand ever dreamed that the war had anything to do with "the balance of power"; and few would have known what it meant if it were suggested to them. They were fighting the Germans, because the Germans were brutalizing mankind, violating International Law, and destroying people's homes. And there is not a man of them who would not fight again for the same reason. !!!*?? \& bitt!!..

$\mathrm{We}$ do not wish to be misunderstood in Europe by the representation that we went into this war with the purpose, or for the end, of creating a "League of Nations." We have not, as a people, studied the project. 


\section{THE ENTENTE OF FREE NATIONS}

We do not all even know what it is. There are many full-fledged and very ingenious schemes for a "League of Nations" which palpably contradict one another. Of one thing some of us are sure, we do not wish, or intend, to be bound in the dark, or to be controlled by abstract terms that would make us shrink from keeping our obligations in a concrete way; and we know that nothing is more illusive than the requirements of a treaty, unless it is very precise and treats of matters clearly and definitely known. We, as a people, went into this war to prevent Germany from throttling the world, our own country included, as she had done to Belgium, and Serbia, and whoever else opposed or did not aid her. It was not to secure for her a place of equality in a society whose laws and whose material interests she had deliberately planned to destroy, that two million peaceful American citizens put on their uniforms and went to Europe over seas in whose waters torpedoes lurked and mines floated. It was to render this savagery impossible. 


\section{PROBLEMS IN FOREIGN POLICY}

We have not, however, to read far before we discover that it is not a league in the sense of a mere legal compact, with minutely specified obligations, that Mr. Austin Harrison has in mind. "The real problem in a League of Nations is, to my mind," he says, "not the sanction--that the soldiers will see to on their return-not the machinery, not the tribunal, not the immediate dispensation of justice, but the creation of a regularized cooperation capable of the necessary flexibility and progressiveness, which alone can give it the life of durability." In brief, it is not a treaty signed by diplomatists, but a union of consciences in a common cause of justice that is to save the world. Of this no American soldier, I think, would need to be convinced. It was a consciousness of this in his own understanding that made him accept gladly his marching orders.

In another article in the same Review, Austin Harrison, to illustrate his meaning, cites the words of the President of the United States uttered on September 27th, 1918: "It is the peculiarity of this great 18 


\section{THE ENTENTE OF FREE NATIONS}

war that, while statesmen have seemed to cast about for definitions of their purpose and have sometimes seemed to shift their ground and point of view, the thought of the mass of men, whom statesmen are supposed to instruct and lead, has grown more and more unclouded, more and more certain of what it is they are fighting for. National purposes have fallen more and more into the background, and the common purpose of enlightened mankind has taken their place. The counsels of plain men have become on all hands more simple and straightforward and more unified than the counsels of sophisticated men of affairs, who still retain the impression that they are playing a game of power and playing for high stakes. That is why I have said that this is a people's war, not a statesman's. Statesmen must follow the clarified common thought or be broken."

These are words as true as they were nobly spoken. They have given to the man who uttered them an unprecedented prestige. In words equally true and noble, Mr. 


\section{PROBLEMS IN FOREIGN POLICY}

Harrison expresses the expectations which they inspire. "In place of diplomacy acting in secrecy for purely selfish or national motives, Europe is bidden to regard the opportunity of the whole, bidden to the law of a commonwealth." This is assumed to be the message of America that is to save Europe.

Unfortunately, this message is enveloped in a nebula shot through with seeming contradictions. "It is not," Mr. Harrison continues, "a question of juridical form and formula. Its sanction must be inborn, induced-the evolution of harmony. Peace can never be established on a durable basis through the organization of international councils of control; by police machinery; still less by penal or constrictive impositions. That is the old-the Napoleonic, the German-way. . . All must go to the table of peace ready to give and to give up; to found a charter of international rights based not on force, but on the sanction of free peoples."

This might well be the message of America; though perhaps rather puzzling to the members of the League to Enforce Peace. 


\section{THE ENTENTE OF FREE NATIONS}

But what is the authority for it? Who has been charged to deliver America's message? Who has formulated it? Who has explained it?

In glowing words, Mr. Harrison reiterates the thought that Europe is to be somehow saved by America. "Either an attempt to restart Europe on some accepted law or morality of coöperative utility instead of competitive force with the object of removing the causes of war, or we shall achieve nothing permanent," he declares. And it is America that is to give the start. And he tells us in what manner. "I can only repeat," he says, "what I have urged again and again, that national conferences should be convened, charged to offer their concerted advice upon the problems of the subject peoples; that these conferences should consider concurrently a common agenda; that the proceedings of all these conferences should be made public, and that they should be in daily telegraphic communication with one another. Something of the kind has been done in France, but here (in England) 


\section{PROBLEMS IN FOREIGN POLICY}

we have heard of no such assembly of intellect. A Declaration of Rights can hardly issue from a bureaucracy; it must come from the clash of the best minds of democracy, thinking aloud. . . For the problems are not only international, they are also national, and the danger to the constitution of the new fabric of laws will be found in their application. That is why the collective wisdom emanating from these National Conferences would seem the indispensable condition of the success of any permanent International Law. ... Now the antecedent condition to such a Law of Nations must be a Declaration of Rights."

What progress had we, the American people, made in this direction when the Peace Conference met at Paris? We are assumed to have felt, - we are said even to have imparted to Europe,-the impulse toward a better international adjustment; but what channel for its expression, what mechanism for its effective operation, had been deliberately even discussed either by or before the people? "The voice of the people must 


\section{THE ENTENTE OF FREE NATIONS}

make itself felt, directing the voice of the Conference," we are told; "for only so can there be any 'demonstration' of the new thought essential to release, or any manifestation of sacrifice." What an opportunity then has been missed, to say openly what sacrifices are expected of us? What obligations are to be incurred by us? What legal forms are to be accepted by us, in the great process of creating an international government which, in important matters, will supersede our own? for that is what is implied in a "League of Nations."

I shall not attempt to enter here upon any analysis of the various ingenious drafts of an international constitution, as the fundamental law regulating the legislative, judicial, and executive powers of such an international government,-a government which, within its sphere, will control the governments of the nations that subscribe to it. One thing, however, is plain, that to possess any efficiency these powers must detract in important ways and in large degree from the powers of the national governments and in- 


\section{PROBLEMS IN FOREIGN POLICY}

volve a considerable sacrifice of their sovereignty. It is true, on the one hand, that sovereignty in what are called the "democracies" has been gradually transferred from a personal absolute monarch to the people, or to some portion of them; and it is also true, on the other hand, that the conception of sovereignty in constitutional States has been to some degree modified by the recognized limitation of the irresponsible use of force and the addition of ethical elements in its exercise. In brief, no people can rightly claim to possess rights in proportion to their power, and sovereignty cannot, in a juristic sense, be longer regarded as strictly absolute. In every State founded upon the rights of persons, which is the basis claimed by democracy, the rights of the whole people cannot exceed what is necessary to the maintenance of the right of each.

In proportion as they become republican, as Kant contends, States may find it easier to combine in federations than was the case with absolute monarchies; still, even republics are jealous of their sovereign powers, 24 


\section{THE ENTENTE OF FREE NATIONS}

and they are not disposed lightly to surrender them. Every scheme for a League of Nations requires this surrender in some degree, for every such league creates in some form a supernational body of control, to which the members agree to submit. Membership in such a league, of necessity, implies the renunciation of any independent foreign policy.

In a world composed of nations varying in culture, character, education, and honor, as well as in numbers, strength, and military traditions, such a renunciation cannot wisely be made without unusual assurances, and it cannot be universal. If made at all, it must be made for the sake of advantages not otherwise attainable, and for an association that is beyond suspicion. A league which had for its object to enforce peace, without specific foreknowledge of the occasions that might call for its exercise of the war-making power, could not be wisely created except between nations of the highest moral responsibility and mutual confidence, and could never safely be allowed to include any nation 


\section{PROBLEMS IN FOREIGN POLICY}

that could not be trusted to accept and obey the decisions of a tribunal to which it might consent to submit a difference.

A league professing to be composed only of "free nations" would rest upon a basis of an extremely ambiguous character. What nations are to be classed as "free"? Certainly no nation that holds in subjection any people not permitted to enjoy self-government. And the mutability of nations must not be overlooked. The expression "free nations" is especially equivocal in a period of revolution and transition, like the present. Neither Russia, nor Austria-Hungary, nor even Germany could claim a place in it, nor could the fragments into which they may possibly fall before the movements of revolt or secession are completed. And what is to be said of the suppressed nationalities which are aspiring to independence but have not yet attained it?

Is it not a little singular that the course of events and the effort to control them by general principles should have led men to claim that the coming peace should include such 26 


\section{THE ENTENTE OF FREE NATIONS}

logical antinomies as a partial renunciation of national sovereignty and the complete attainment of self-determination?

The origin of the problem is more evident than its solution. On the one hand, some nations are regarded as too independent, too powerful, and too aspiring, to be considered safe for the rest of the world, unless they are willing to have imposed upon them certain restraints which equality seems to require; while, on the other, some nations are too much oppressed, too feeble, and too submissive, to assert the national rights which even-handed justice would assign to them.

We are here confronted with the indisputable fact of the natural inequality of nations, and this disparity extends to every circumstance of national life, except one. Juristically, all independent and responsible States, whether large or small, have equal abstract rights to existence, self-preservation, self-defense, and self-determination; but culturally, economically, and potentially they are, and must remain, unequal. If they enter a "League of Nations," they must en- 


\section{PROBLEMS IN FOREIGN POLICY}

ter it upon terms which the strong are disposed to grant to the weak and which the weak are obliged to accept from the strong. It is evident who will make the laws. But if self-determination is a right, and its realization is possible only through the exercise of force, who shall say that a suppressed nation may not plan and achieve its own development, as the greater States have done? Shall the great empires impose upon the world an unchangeable status of their own devising; or shall the Balkan States, for example, agree upon their own boundaries and affiliations?

The problem of adjustment is further complicated by the fact that the modern nation is no longer a merely juristic entity, having for its only object the maintenance of order and justice among its own inhabitants. 'It has become an economic entity, a business corporation, looking for markets for its commodities and for raw material from which to manufacture them. The State owns mines, railways, steamships, colonies, and uses them as means of increas- 


\section{THE ENTENTE OF FREE NATIONS}

ing its own power of control over the products and the markets of the world. Will it open its house to the passer-by, invite him to its banquet-board, and share with him its accumulated treasures?

This is a question which time will answer. And a very short time has sufficed for a partial response. Every one of the Powers is now planning how it may increase its trade, and how it may extend its control over natural resources.

In so far as the object of a "League of Nations" is to prevent this rivalry from becoming dangerously acute, its purpose is no doubt commendable; but the danger it involves is, that, in striving to enforce a legal compulsion, it may be felt to be oppressive, -a new type of multiplex imperialism in place of the old. In one respect, at least, this danger is imminent. If a "League of Nations" proves to be a device to compel independent nations to make economic sacrifices for the benefit of others, and establishes a central control of resources which becomes a dispenser of benefits which the beneficiaries 


\section{PROBLEMS IN FOREIGN POLICY}

have not aided in creating, then the League will prove a bondage that will be resented, and will not be endured. It is very appealing to our better natures to inform us, that the future is to be "a life of service," in which we must perform a generous part. If this is voluntary, the call may well be a spur to action. But if the "League of Nations" aims to obtain these sacrifices, not by such voluntary action as the associated nations have freely offered to one another during the period of war, by supplies of food, loans of money, free medical service, and gifts of a magnitude which the world has never before known, but by the enforced operation of a legal contract, the call is different. The policy underlying a "League" is that the world's supplies, the world's credit, and the world's military strength, in the name of "equal economic opportunity," together with the "freedom of the seas," whatever that may mean, are to be placed under the control of a central authority,- - an International Council whose decisions shall be paramount and final in the great questions of trade and war. 


\section{THE ENTENTE OF FREE NATIONS}

If nations had not developed into business corporations, and had confined their activities to the realm of protecting the rights of their individual citizens, a "League of Nations" might have meant something quite different from this. Laws of a universal character might have been readily assented to for the uniform protection of individual persons which it is now difficult for sovereign Powers to accept as applying to themselves. This is particularly true when international restraints are directed against perfect freedom in national fiscal policy. No nation whose citizens are required by their habits and climate to maintain a high standard of living, or suffer deterioration by lowering it, can afford to bind itself to grant equal terms to imports, especially manufactured articles, from all countries alike. They would soon find their working classes reduced to starvation wages accompanied by the total paralysis of many lines of industry as a consequence of an enforced competition with lower races, living in climates and under conditions where the customary standard of life 


\section{PROBLEMS IN FOREIGN POLICY}

can be maintained at a trifling cost, while foreign employers were reaping rich harvests of profit by exploiting practically subject peoples.

Under such a régime, the people of the United States would suffer more than any others, for the reason that their standard of living is the highest in the world. It is on this account that by voluntary sacrifice the United States has been able to rescue from starvation and to supply with needed commodities the impoverished nations of the world. This has been one of their chief contributions to the Great Understanding, the Entente of Free Nations, in saving from ruin the countries overridden by centralized economic power. It has been possible because personal initiative and enterprise, protected and left free to achieve its own development without absorption by the State, had accumulated forces and agencies which, being free, were in reality the most efficient in the world. Without that freedom and without that protection, the contribution of America in the war would have been impos- 


\section{THE ENTENTE OF FREE NATIONS}

sible. Our country would have been in a state of colonial dependence upon the great manufacturing centers of the European nations.

Our interest and our policy are, therefore, plain: first of all, to hold fast to our freedom; and, next, to prevent from falling into desuetude that unwritten charter of union which constitutes the Entente of Free Nations, cherishing its unity of purpose as the most precious of human achievements. It is a moral, not a legal unity, that has given us the victory. Uncovenanted armies have gathered from every quarter of the globe to assert the determination of the free nations that the rule of arbitrary force shall be ended. Our sons and brothers have been among them. Together they have faced death and have shed their blood, and men of many nations sleep in common graves. It is the most splendid assurance for the peace of the world and the rule of justice that can be imagined. The sense of comradeship in a holy cause cannot perish. A new Brotherhood of Men has come into being. Let us not mar its 


\section{PROBLEMS IN FOREIGN POLICY}

simplicity by distrust or controversy, or try to force upon any of our co-belligerents any untried theory of legal union which might be honestly rejected, or accepted with doubt and reluctance. The battle has been fought in the name of freedom. Let us remain free in the hour of victory.

But in our freedom there are certain principles which must not and will not be forgotten. They will control the practice of the Entente of Free Nations, which must continue with its present provisions for conference, discussion, and united action. A marked step of advancement has been taken in the recognition of the principle that all international engagements and undertakings must be justified by the moral law and must have publicity. A formal covenant in this sense may be found possible, and it may take a solemn legal form; but, whether this be the case or not, the war has established a few precepts that will, undoubtedly, be admitted to a permanent place in the code of international right. No treaty between nations should be considered binding unless it is pub- 


\section{THE ENTENTE OF FREE NATIONS}

lished when it is made. No negotiations affecting the destinies of peoples should be conducted without their knowledge of the fact and of the obligations to which they are to be committed. No war should be begun without a public statement of the reasons for it and an opportunity for public mediation between the disputants, which should never be considered an offense. No territory occupied in war should be claimed by right of conquest without a public hearing of all who are affected by it.

The attempt to state these, or any, definite principles, illustrates how inadequate a strictly documentary form of engagement of necessity must be. It is, however, the spirit, not the form, that must be depended upon for the security which a formal treaty of alliance or an understanding can afford. The whole structure of international peace and justice rests upon the character of the peoples who form the Society of Nations. The Great War has subjected the combatants to a fiery test. It cannot well be doubted that the Entente of Free Nations will 


\section{PROBLEMS IN FOREIGN POLICY}

stand also the test of peace. A solidarity that has been only strengthened by the dangers of battle will certainly not be broken in the attempt to revise the Law of Nations, to make it the basis of clearer understandings, and to increase the confidence with which the co-partners in victory will bring before the judgment bar of reason the differences that may tend to divide them. But the perfection of this understanding is a matter of growth and of gradual adjustment. What cannot be accomplished by a stroke of the pen at a given moment of time may prove an easy task if the spirit of the Entente, and especially the sense of freedom which brought it into being, can be retained and matured. But this can be done only by a renunciation of the desire to force any favorite plan to an issue within the Entente. For a considerable time, unless new dangers are to be incurred, armies and navies will be necessary to guard the peace that is to be signed at Versailles. It will be wise to maintain the supremacy of the forces that will have made it possible. For this the respon36 


\section{THE ENTEN'TE OF FREE NATIONS}

sibility rests upon all, according to their strength. And because they are strong they may, by the constancy, justice, and unselfishness of their conduct, prove to all mankind that really free nations alone can preserve the peace of the world. 
GERMANY'S POSE FOR PEACE

THe peace to which Germany was looking forward when, in October, 1918, the armistice was requested, was expected to be arrived at by a process of bilateral debate on the meaning of the fourteen rubrics of peace proposed in January, 1918, by the President of the United States. Those rubrics, it was thought, were so broad in their scope and so indefinite in some of their applications, that it appeared possible so to interpret them as to procure for Germany a peace that would, in effect, be a greater victory than the German armies could ever hope to secure by war. The policy that was then adopted and has since been dominant in the German mind is an effort to obtain an economic victory at the cost of a military surrender,-an economic victory which would completely justify an 


\section{GERMANY'S POSE FOR PEACE}

acknowledgment of military defeat if it could be secured by the acceptance of the German construction of the fourteen rubrics considered as the terms, and the only terms, of peace.

Little information, it is true, was given publicity regarding the plans and policies of Germany for securing the most favorable peace. It is, perhaps, not without a purpose that comparative silence on that subject has been preserved; still, there has been a very distinct outcropping of what was latent in the minds of German diplomatists. "All the belligerents," Count von Bernstorff allowed himself to say, "have accepted the President's fourteen points, and the only question to be discussed is their interpretation." The new German Secretary for Foreign Affairs, Count von Brockdorff-Rantzau, made a similar statement, and the "Tageblatt" of Berlin supported this view with the declaration, "No peace must be signed which differs by the breadth of a hair from the principles of President Wilson's fourteen points, which Germany has ac- 


\section{PROBLEMS IN FOREIGN POLICY}

cepted, and the Entente willingly or unwillingly has signed."

It is needless here to repeat the interpretations of which these rubrics seem to be susceptible. It is sufficient to note that they were held at Berlin to provide for the following privileges which, after peace, Germany, equally with other nations, might be permitted to en'joy, under the protection of "mutual guarantees of political independence and territorial integrity" provided by "a general association of nations":

1. Absolute freedom of navigation upon the seas, alike in peace and in war;

2. The removal of all economic barriers, and the establishment of an equality of trade conditions;

3. Free and open-minded adjustment of all colonial claims, unprejudiced by the actual results of the war;

4. Entire national self-determination, which would logically include perfect freedom in choosing and maintaining a future form of government; and 


\section{GERMANY'S POSE FOR PEACE}

5. Admission on equal terms into a general League of Nations.

A peace based upon these conditions, and involving only the surrender of what Germany had no claim to before the war, would render her not only a victor in all the substantial elements of victory, but would leave her in population the largest political unit on the Continent of Europe, with a clear accession by union with Austria of more than eight million of the Teutonic race; and, after extruding some four million of her present subjects belonging to other races, would give her a net gain of some four or five million souls and a considerable amount of new territory. When the peace was signed, the zone of occupation evacuated, and the occupying troops demobilized, Germany, whether a republic or a monarchy, the choice being freely open to her, with untouched economic resources and organization, no matter what proportionate disarmament might be imposed, would be by far the strongest military state in Europe. She would possess racial unity, territorial enlargement, economic pre- 


\section{PROBLEMS IN FOREIGN POLICY}

eminence on the Continent, and military security. Even though she had not been defeated in the field, such a peace would be an advantageous one for Germany to make, a more satisfactory one indeed than she could ever hope to win by the victory of her armies on the field of battle.

How then has Germany hoped to secure such a peace?

The course of procedure was clearly marked out for her. Such a peace could never be made with the Kaiser as the head of the Empire. That had been plainly declared. What, above everything else, was demanded of Germany was that she should repudiate her Hohenzollern dynasty and take her place among the nations as a free, self-governing people; for a "people," it was assumed, when it takes government into its own hands, is always just, honorable, and trustworthy; while rulers alone are untrustworthy. Let the rulers and the military caste, therefore, be repudiated, and peace would be easily obtainable.

What nation, weary of a fruitless war, 


\section{GERMANY'S POSE FOR PEACE}

seeing its army, after a supreme effort to break through the enemy's reinforced lines, steadily and inevitably retreating, its territory about to be invaded, its cities bombarded and assaulted from the air,-what nation, I say, could be expected to miss such an opportunity to make a profitable peace?

Germany was too prudent to lose such a chance of advantage. The Kaiser's own appointed Imperial Chancellor, accountable only to him, therefore asked for an armistice, in order that such a peace might be negotiated.

"Who are you, who ask for an armistice, with a view to peace, and whom do you represent?" was, in effect, demanded of the Imperial Chancellor. "Do you speak for the German people?"

The Imperial Chancellor was silent. How could he speak for the German people, with whom he had nothing to do, and to whom he was not responsible? The answer must be better staged.

It is a new officer, therefore, the representative of what poses as a new government, 


\section{PROBLEMS IN FOREIGN POLICY}

the Secretary of State for Foreign Affairs, who responds to the question intended for the Imperial Chancellor and writes for him a certificate of character.

"The present German Government," he declares, as if speaking by some new popular authority,_"the present German Government, which has undertaken the responsibility for this step toward peace, has been formed by conferences and in agreement with the great majority of the Reichstag. The Chancellor, supported in all his actions by the will of this majority, speaks in the name of the German Government and of the German people."

Thus, at last, the long silent "German people," the presumably just, honorable, and trustworthy German people, who were assumed not to be responsible for the war, but rather the victims of a false and shameless autocracy too infamous to be dealt with had, it was made to appear, really spoken. They had spoken, however, only through the voice of a "great majority of the Reichstag,"-a body which from the beginning had with 


\section{GERMANY'S POSE FOR PEACE}

unanimity supported the war and all its atrocious procedure; a body which only for a moment found a voice with which to speak the mind of the people and having been for that one moment indistinctly vocal, has since subsided into the silence of the grave! If the German Reichstag really represented the German people, why in this great emergency did it not remain at its post of duty?

Germany, in that fateful hour, seemed to prefer to have no responsible government. Was it because it is more difficult to hold accountable, and on that ground to condemn and punish, a nation without a responsible government than a nation which can be on specific charges indicted and arraigned for its past misdeeds?

Say what we will of the Kaiser's personal régime, it was at least one which, whether trustworthy or not, could be held accountable for its crimes. But the Kaiser's Government was alleged to be no longer in existence. In order that it might disappear, he was urged to abdicate. He professed to have done so, and went to Holland. Germany 


\section{PROBLEMS IN FOREIGN POLICY}

appeared satisfied, but the outside world demanded the evidence of his abdication; and it was not till three weeks after his retreat, that, in order to satisfy foreign demands, on the 29th of November, a document was finally signed by the alleged ex-Kaiser.

The reason for his withdrawal from Germany William II himself frankly stated. "I go to Holland," he is reported to have declared, "in order to facilitate peace"; and no one has contradicted this statement. The German people, it seems, when the Kaiser's armies were beaten in the field, suddenly wished him gone, sent forth, as it were, like the "scapegoat" of ancient times, into the wilderness, not because his people hated him or considered him an arch-criminal, not because they themselves wished to destroy him - as they had, and still have, an opportunity to do-but because it appeared that he might be laden with their sins, and his going with this burden would "facilitate peace" by consigning responsibility to the wilderness of oblivion.

And why was it supposed that his going 46 


\section{GERMANY'S POSE FOR PEACE}

would facilitate peace? Was it not because an irresponsible nation can demand easier terms than a responsible ruler?

The just, honorable, and trustworthy "people of Germany" seemed to be pleading at the judgment bar of history, and preparing to say at the peace table: "We demand peace because we are an innocent and a defenseless people. First of all, we are a 'people,' and how can you punish a whole people? Has it not been said that there is something sacred and sacrosanct in a 'people'? You are trying 'to make the world safe for democracy.' We are now a democracy. See, we have dismissed the Kaiser! We shall have no more of him. Have mercy upon us, Kameraden! We accept all your glorious democratic principles. Now, undoubtedly, you are ready, since you would make the world safe for democracy, to make our democracy an asylum of safety for us!"

Here was a change of plan, but was there any change of heart behind these pretensions? Have all Germans, or most Germans, suddenly become Social Democrats, clamor- 


\section{PROBLEMS IN FOREIGN POLICY}

ing for a Socialist Republic? Where are all those millions of troops? Where are all those hundreds of thousands of officers, those Prussian generals who are said to have made the Kaiser declare war? Have they gone to Holland? Only a few of them. The vast majority, armed, organized, waiting for a word of command, were in Germany; and they were silent, as silent as the Reichstag. Why were they silent? They were silent because silence was the order of the day, a token of irresponsibility and acquiescence in a new order of things. They were waiting to see if an economic victory could be won. If it is won, they will have their reward. If it is not won, they will, perhaps, have something to say in the future when the peace has been concluded, and is yet to be executed, when the Allied armies are demobilized, and when the rest of Europe has gone to sleep.

There was, before the armistice, no serious revolution in Germany. There had been hunger, there had been weariness, there had been joy at the cessation of battle, there had been a vision of peace, of comfort and tran- 


\section{GERMANY'S POSE FOR PEACE}

quillity. There had been also an emergence of Bolshevism, the weapon which Germany skillfully forged and thrust into the vitals of Russia; but Germany expects to receive no serious wound from this weapon. There was no clear evidence of change in Germany, no movement beyond street fights and bread mobs, such as may occur in any city when the conditions of life are hard and when the passions of low-browed men are for a time let loose. The Councils of Workmen and Soldiers solemnly infested the Herrenhaus under the protection of a machine-gun; but the generals knew that at any moment in Germany they could make short work of all this assemblage of the rags and tatters of Bolshevism. But the time was not opportune. The disease of Bolshevism, in so far as it is a social malady, may safely be permitted in Germany to run its course. It illustrates to the middle-class what the dangers of democracy may be. It shows to the world how wide the infection may become, if peace is not quickly made. It presents to the Allies the puzzling problem how 


\section{PROBLEMS IN FOREIGN POLICY}

to obtain redress from a people who disavow accountability and are too broken and disorganized to enforce the duties of a responsible State.

How real is a revolution when the domestic courts are in session, when the bureaucracy is administering affairs, and when life and property are not in great immediate peril? The Germans are an exceptionally orderly people. Their demonstrations are customarily innocuous. Their habits of life are prudent. Their burghers are not stricken with poverty, and their proprietors, accustomed to the use of arms, are able to guard, and are determined to defend, their own material interests. When a real revolution appears, if it does appear, they will unite their forces and rally to their own protection. What they have wished to exhibit to their conquerors was a starving population incapable of bearing new burdens, an unsettled public order that might prove a contagion to their neighbors, an effort for democracy that would be taken as an apology for the past, and above all a situation which would 
excite the sympathy of the credulous and the support of class interests of a revolutionary temper in the population of those countries which they would represent as their oppressors for capitalistic gain.

You wish the evidence of this? Then listen to the speech of Hindenburg to his army, on November 13th at the moment when he had decided that it was an economic rather than a military victory for which Germany was to look. Does he pretend that he or they had fought under merely autocratic orders? Does he confess that the course of Germany was wrong? Does he call for a change of heart, or merely for a change of policy? He says:

"Germany up to to-day has used her arms with honour. In hard fighting the soldiers have held the enemy away from the German frontier in order to save the Fatherland from the horrors of war. In view of our enemies' increasing numbers and the collapse of our allies and our economic difficulties, our Government was resolved to accept the hard terms of the armistice; but we leave the fight, 


\section{PROBLEMS IN FOREIGN POLICY}

in which for more than four years we have resisted a world of enemies, proudly and with heads erect."

If we turn to what calls itself a government of democracy, what do we hear from the alleged Premier, Ebert, when he welcomed the troops coming home to Berlin? Does he repudiate the purpose of the war? Does he inform the returning soldiers that they have made useless sacrifices, or have been engaged in an unworthy cause, at the command of an autocracy in whose downfall they should rejoice? Tens of thousands of men march by still bearing their arms, filing between other tens of thousands of people who are supposed to have made a revolution, who welcome them as joyful spectators, the troops laden with garlands, as they tramp on to the loud blare of bands of music intoning, "Deutschland, Deutschland über Alles."

"Your deeds and sacrifices," the Premier declares, "are unexampled. No enemy overcame you. Only when the preponderance of our opponents in men and material grew 


\section{GERMANY'S POSE FOR PEACE}

ever heavier did we abandon the struggle.

"You endured indescribable sufferings, accomplished incomparable deeds, and gave, year after year, proofs of your unmistakable courage. You protected the homeland from invasions, sheltered your wives, children, and parents from flames and slaughter and preserved the nation's workshops and fields from devastation.

"With deepest emotion the homeland thanks you. You can return with heads erect. Never have men done or suffered more than you."

Is this a proclamation of democracy? Is the world to be "made safe" by this adulation of a career of national crime? What can be said after this to the heroes who are told that in serving the Kaiser they were nobly defending the Fatherland, if for this glorious service they are asked to toil in the fields and the workshops to pay for the damage they have done to Belgium, to France, to Poland, and to other lands which they have, without just cause, ruthlessly invaded and cruelly devastated? Can they be urged to make rep- 


\section{PROBLEMS IN FOREIGN POLICY}

aration? Or will they think it unjust that, having suffered so much in a cause so noble, they must be treated as if they were the perpetrators of outrages for which they, their children, and their children's children must be held accountable?

Here is no note of penitence or contrition. It is the same Germany, speaking with the voice of Hindenburg and Ebert, which accepted the Kaiser as its glorious War Lord, that believed, or professed to believe, in the divine right of conquest, and threatened innocent nations with the extortion of enormous indemnities, covering not only the total cost of their exploits but sufficient to enrich the nation and render it the most opulent in the world.

The attitude of Germany in accepting just conditions of peace, will be the test of the character of the German people with whom in the future other nations must live and deal. The first necessity to a recognition of reformation is the disposition to repay, in so far as that is possible, at whatever sacrifice, the damage they have inflicted. 


\section{GERMANY'S POSE FOR PEACE}

If exemption from this obligation is claimed on the ground of irresponsibility, it will imply a degradation of character as deep as that evinced by the predatory enterprise in which all Germany was to profit by collecting the costs of the war from its innocent victims.

Without reparation for the injuries inflicted, there can be no real peace. The example of such an unpunished exploit would remain as an encouragement to future crime.

Will the German people, whose sense of justice, honor, and moral obligation is now to be put to a crucial test, voluntarily accept the burdens which a just peace will impose upon them? If not, what confidence can be placed in the proposal to make the world safe for democracy, and what will be the world's judgment upon the ethical standards of democracy itself? We shall learn from the conduct of Germany whether or not we are to ascribe all the enormities of the war to the depravity and malevolence of her rulers, against whom, until the moment of defeat, the people offered no protest; and 


\section{PROBLEMS IN FOREIGN POLICY}

whether or not a people, left free to express its own character, will accept the burdens of an act of justice.

On account of the Great War, in which their duty rendered it necessary that they should participate, the people of the United States of America have not only freely offered to the cause of justice the lives of tens of thousands of their sons, but have paid, or will have paid, probably over thirty billion dollars, which they have not yet demanded should be returned to them. The whole expenditure of the war, by the Allies, considered merely as a matter of monetary sacrifice, is said to exceed two hundred billion dollars; and yet this gigantic sum, which it will require generations to make good, is one of the least and one of the most easily repaired of the damages inflicted by this assault upon humanity.

The manufacturing plants of Germany are practically intact, and their escape from devastation affords the Germans every advantage over their neighbors in the resumption of their normal industries. The loss of 56 


\section{GERMANY'S POSE FOR PEACE}

man-power through death and mutilation may amount approximately to three or four million men, but this loss will probably be made good to the extent of at least one-half by the growth of population during the period of nearly five years from the beginning of the war to the conclusion of peace.

The greatest hardship for the Germans will be the deficiency of raw materials for manufacture; such as cotton, wool, copper, iron, rubber, and many others. They will doubtless plead for these as absolutely essential to them. If they were wholly withheld, it would, of course, be impossible for the Germans to pay any indemnities, because they can only pay to the extent to which they are able to earn the means of payment.

If, however, this argument should prevail, its inevitable consequence should not be overlooked. If raw materials are furnished to the extent of Germany's demand, German manufactures will at once obtain an immense acceleration, German goods will flood every market, and the less favored countries will be driven out of the world's marts by 


\section{PROBLEMS IN FOREIGN POLICY}

an excess of German production and German methods of commercial exploitation. It would not require many years for Germany, with these advantages, even though promising the payment of heavy money indemnities, to have so taken possession of the world's markets as to make the arrangement a profitable bargain. While the Belgians and the French were slowly recovering their productive capacity by a restoration of their ruined industrial plants, Germany would completely forestall them in securing foreign trade. Such a programme would, in effect, be the formation of a partnership in which, to secure a portion of Germany's gains in the form of an indemnity, they would surrender to her the conduct of foreign business, while they themselves were engaged in merely recovering to some extent the productive efficiency of which Germany's invasion has deprived them.

To appreciate the full significance of such an arrangement, it is necessary to consider that, while Germany's manufacturing plants have not been in any way impaired, and are 58 
GERMANY'S POSE FOR PEACE

ready to begin operation, those of Belgium and Northwestern France have been practically destroyed. It is reported that 26,000 factories in the French districts occupied by the Germans were either wholly demolished or stripped of their machinery; which, with the looms and other portable means of industry of Belgium, have been carried into Germany. Thousands of square miles of rich agricultural land have been so deeply plowed with shells as to be utterly unfit for cultivation. Houses and public edifices have been left in ruins and can be replaced only by years of labor. Valuable mines have been rendered useless, and it will require both time and expense to restore them. It would be unjust, even though the money value of all these objects were eventually paid in cash, to impose upon the inhabitants of these devastated countries the concentration of all their skill and labor upon the work of reconstruction while those who had destroyed them were profiting by expanding their own world-wide trade. At the end of the period when the restoration was complete, the 


\section{PROBLEMS IN FOREIGN POLICY}

money paid would have been spent in the work of reconstruction, and these unfortunate countries, having in the meantime devoted their energies entirely to this task of restoration, would be no better off than they were when the war began, while German industry and trade domination would in the meantime have been definitely and perhaps permanently established.

The remedy which justice would seem to demand is evident. Whatever of value has been carried into Germany should be immediately brought back and replaced. The reconstruction of houses, factories, and other edifices should then be speedily brought to completion by German workmen at Germany's expense, aided by those natives who for the time being have no other employment, all their labor to be paid for by Germany. In so far as the German shipyards can replace the tonnage destroyed, they should be at once employed for the purpose; and only such ships should be allowed for German trade as may be necessary for the distribution of Germany's just proportion of over- 


\section{GERMANY'S POSE FOR PEACE}

seas commerce. The other forms of indemnity would not be cancelled by this process of restoration; but the liquidation of these obligations might be ultimately accomplished by the saving of all expense for military purposes beyond mere domestic police duty in Germany, by special import licenses on German goods, and by the appropriation of a percentage of the profits of Germany's coal and potash mines.

This would be undoubtedly a heavy burden for a conquered people to bear; but it is less than it was the German purpose to impose upon the innocent victims of their imperial schemes of conquest.

Has the alleged German democracy any intention gracefully to accept such obligations?

It will be noted that under the fourteen rubrics of peace proposed by the President of the United States, reparation and indemnity are not included. "Belgium," the seventh rubric declares, "the whole world will agree, must be evacuated and restored;" but the restoration here referred to, as the fol- 


\section{PROBLEMS IN FOREIGN POLICY}

lowing words imply, seems to relate to "the sovereignty which she enjoys in common with other free nations," while no mention is made of the reparation of material damages.

Under the eighth rubric it is proposed that "All French territory should be freed, and the invaded portions restored"; but the implication here appears to be the same as that under the seventh rubric. In both cases it is the restoration of territory, not reparation that is specified.

The truth is that, in a military sense, Germany was defeated. Her generals have admitted that it was useless to continue the fight. Had no basis of settlement been proposed, the alternative to the invasion of Germany by the Allies and an allied victory proclaimed at Berlin would have been an immediate unconditional surrender. The terms of the peace would then have been the conditions to be laid down by the conquerors. Who then will deny that there would have been a clearer case for the conditions which the Allies must in justice impose, and less opportunity for a plea that only the four- 
GERMANY'S POSE FOR PEACE

teen rubrics should be discussed and Germany's interpretation of their meaning considered, if the surrender were in no way connected with the alleged "terms" which both belligerents are assumed to have accepted?

As the case stands, Germany claims the right to voice her interpretation of those "terms," and will insist that they be regarded in their entirety as a body of conditions, each involving the others. It will be urged that conditions ought not to be made more burdensome for a new popular régime in Germany than were contemplated at the time the armistice was signed and the alleged "terms" accepted, while the Kaiser's culpable Government was still in command.

All these claims and pleas must prove unavailing, for the reason that they are not just. What gives them plausibility is Germany's assertion that she was led to expect an advantageous peace on certain conditions, and that those conditions have now been fulfilled. One implied condition was, it is held, that a free people could receive better terms than a guilty autocracy. The specific terms 


\section{PROBLEMS IN FOREIGN POLICY}

of peace were contained in the fourteen rubrics. On these "terms" a nation that still takes pride in the cause for which its armies fought, that abandoned the struggle only beeause its force was exhausted, and that has made no apology for a crime in which it participated, now demands to be received as an equal partner in an international order yet to be established; if, indeed, any "general association of nations" can ever be formed which will "guarantee" the conditions which these rubrics suggest.

All this does not destroy, and it should not obscure, the demands of justice to the nations that have suffered invasion and devastation at the hands of Germany. The whole scheme of the rubrics aimed at compromise. If it has really deceived Germany, or if its application should leave any of the injured without redress, it was, indeed, morally and diplomatically a mistake. The demands of justice, however, remain unshaken. There can be no binding agreement to do wrong or to escape doing what is right. The alleged terms of peace may have to be inter- 


\section{GERMANY'S POSE FOR PEACE}

preted again and again; but, wholly irrespective of any interpretation, complete reparation by Germany should be made in Belgium and France, not to mention other devastated countries, or the coming peace will be as wicked as the war.

"No State," says Maximilian Harden, who now assumes the rôle of interpreter of the Germany of which he has long dreamed, -"no State that was snatched along into this flood of the Deluge can expect other indemnity than those which can be effected by thrift and savings"; which, he makes clear, must be the effort of each people for itself. There are to be, then, no indemnities paid by Germany. "Taxes and customs duties," he says, "that would yield even the interest on the tens of billions of debt, would necessarily paralyze trade and industry in competition with America, Australia, and the Yellow World; would necessarily grind to bits the idea of private property. . . What then shall happen? Something that has never happened before. . . L Let Europe's war debt become a treasure of atonement. 


\section{PROBLEMS IN FOREIGN POLICY}

Let the war loan certificates of all the European States that have participated in this war ... serve as legal tender, guaranteed by all debtors; a form of money which in every land that is subject to the jurisdiction of the arbitration court must be accepted in payment in any transaction and by any creditor at its full face value!"

Thus all the national war debts, Germany's included, it is proposed, should be pooled in one great "peace fund" and placed under a central control to prevent the outbreak of future war! "The court of the nations," so runs the scheme,-_serves as trustee of the treasurer, and sets aside therefrom in equal parts out of the certificates of indebtedness of all the States what it needs for itself and its militia. It may punish disobedience of its judgments in the case of any individual State by means of a money penalty, declaring valueless all the circulating certificates of that State, calling them in, or destroying them, in the case of any State that breaks the peace without previously being itself bodily and vitally threatened. 


\section{GERMANY'S POSE FOR PEACE}

"Here," this writer continues, "is where a community of European citizenship beckons us. Thus the Continent would be delivered from its money stringency; ... thus it would gently be obliged to bury quickly and deeply the useless reminders of futile conflict."

It is time for Germany, if she would ever regain the respect of mankind, to dismiss such fantastic illusions as these, and to take up the burden of national responsibility in a serious sense. Let her, first of all, sustain a government that will admit the responsibility of the nation for the past, and with which it is possible to deal. Then let that government assume and enforce those obligations which a just peace will certainly impose upon the German nation; not forgetting that the greatest possible calamity to mankind would be to write into the Law of Nations, by absolving the German people from complicity in a national crime, the ruinous principle that a "people" is not responsible for the government it supports, and that it may therefore exempt itself from 


\section{PROBLEMS IN FOREIGN POLICY}

merited punishment by merely changing its form of government.

Has Germany the character to stand this test? When she has proved her ability to do so, then, and only then, can there be a possibility, when years of fidelity have established her good faith, of admitting her to a place in a League of Nations. If those who are gathering to conclude peace cannot now enforce that judgment, then it is more than futile to hope to enforce such a judgment in the future; for the contingencies of a future in which so great a crime was left unpunished would be simply appalling to contemplate. 


\section{III}

INTERNATIONAL LAW AND POLICY

AT no time, perhaps, since history began to be recorded has there existed so profound and so universal a conviction of the value and necessity of law; and particularly of the restraint of law in controlling the activities of independent sovereign States.

Everywhere the necessities, even more than the volitions, of men have in some form, established the authority of the State; whose laws, even though occasionally violated, are regarded as paramount over the populations within their jurisdiction. A comparative study of law discloses the fact that, with slight and almost negligible divergences, the great principles of jurisprudence accepted in all the most highly developed communities are not only similar but virtually identical. As a result, that body of customary law common to different nations, to which the 


\section{PROBLEMS IN FOREIGN POLICY.}

Roman jurisconsults gave the name Jus Gentium, and which became the basis of what we now call International Law, was believed, until the events of the Great War disturbed the conviction, to have attained a consistency of content and a degree of general acceptance by responsible States which placed beyond all serious question its authority as law.

There is, as we all know, some diversity of view as to what constitutes the law in general. If it were otherwise it would be a very stale and unprofitable profession.

As regards the Law of Nations, which has temporarily fallen into disrepute as even more vague and uncertain than other branches of the law, notwithstanding the aspersions cast upon it; there is the highest authority, based on judicial decisions, for asserting with Sir William Blackstone that, "whenever any question arises which is properly the object of its jurisdiction," it is in England "adopted in its full extent by the Common Law, and is held to be a part of the law of the land"; and we may also cite the 


\section{INTERNATIONAL LAW AND POLICY}

opinion of Alexander Hamilton, that it is not only a part of the Common Law, but "has become by adoption that of the United States."

If these vindications of the respectability of the Law of Nations seem somewhat antiquated, I may, perhaps, be permitted to recall the fact that, in his address before the New York State Bar Association, last year, the eminent Attorney-General of Great Britain, Sir Frederick Smith, informed his hearers that when, during the war, it became his official duty to urge upon the Privy Council the idea that no prize court in Great Britain had the right to challenge or call in question the Orders in Council of His Majesty the King, the Appellate Prize Court decided against the contention of the Attorney-General and declared: "We sit here as a Court of International Law, and in spite of what our enemies have done we still believe there are binding doctrines of International Law, and sitting here as we do sit as a Court, whose duty it is to construe those doctrines, 


\section{PROBLEMS IN FOREIGN POLICY}

we utterly refuse to be bound by Orders in Council issued by the Executive."

The Honorable Attorney-General stated that, "whether right or wrong," this was the decision of the Court. The reasons why the Court thought its decision right are fully given by the late Lord Parker of Waddington, in the Report on the case of The "Zamora. "In the first place," he says, "all these matters upon which the Court is authorized to proceed, are, or arise out of, acts done by the sovereign power in right of war. It follows, the King must directly or indirectly be a party to all proceedings in a court of prize. In such a Court his position is, in fact, the same as in the ordinary courts of the realm upon a petition of right which has been duly fiated. Rights based on sovereignty are waived, and the Crown, for most purposes, accepts the position of an ordinary litigant. A Prize Court must, of course, deal judicially with all questions which come before it for determination, and it would be impossible for it to act judicially if it were 


\section{INTERNATIONAL LAW AND POLICY}

bound to take orders from one of the parties to the proceedings.".

"In the second place," continues the Report, "the law which the Prize Court is to administer is not the National, or, as it is sometimes called, the Municipal Law, but the Law of Nations-in other words, International Law. . . . It is obvious that, if and so far as a Court of Prize in this country is bound by and gives effect to Orders of the King in Council purporting to prescribe or alter the International Law, it is administering not International Law but Municipal Law; for an exercise of the prerogative cannot impose legal obligation on any one outside the King's dominions who is not the King's subject. ... On this part of the case, therefore, their Lordships hold, that Order XXIX, Rule 1, of the Prize Court rules, construed as an imperative direction of the Court, is not binding. . . Their Lordships will humbly advise His Majesty accordingly."

It is a grateful and refreshing assurance to all those who believe in and love the reign 


\section{PROBLEMS IN FOREIGN POLICY}

of law, to know that there is, in at least one country in the world, a Court that, even in the midst of war, has the purity and the sense of responsibility to assert, against the Law Officers of the Crown, that it will take no orders from those whose authority is merely the national interests of the moment; but it is still more reassuring to know that, in the judgment of such a Court, International Law, despised, rejected, and reviled by those who should be its champions, not only lives and speaks with a voice of authority, but that its voice commands silence on the part of the interests even of the State.

Happily, this is no new doctrine. For us, as Mr. Justice Gray, speaking for the Supreme Court of the United States, has said, in the case of The Paquete Habana, in 1899, "International Law is part of our law, and must be ascertained and administered by the courts of justice of appropriate jurisdiction, as often as questions of right depending upon it are duly presented for determination"; and it is no reflection upon the loyal 


\section{INTERNATIONAL LAW AND POLICY}

adherence of the United States to this principle that, in appealing to International Law as binding in questions of prize, the British Prize Courts have themselves applied the decisions of American judges to which objection was once raised in the period of the Civil War.

Even a moment's reflection will show that, in determining to decide cases of prize by the Law of Nations, and not under the Orders in Council of the King, the British Court was following a rule of action that was less warped by private interest and more influenced by the spirit of equity. It was, in fact, deciding according to International Law, because it is better law.

And why is it better law? It is better law because it is in no sense ex parte. It is law fit to be made universal. Even in the more liberal-minded States, the development of law is under the restraint of the class of interests that have acquired power, whatever they may be, and proceeds with little control by interests that are just as real but less influential. 


\section{PROBLEMS IN FOREIGN POLICY}

When it comes to the absolute governments, there, Law is merely a decree; and is in no sense based upon its true foundation, which is mutual obligation, recognized and rendered effectual by reciprocal agreement to adopt a controlling principle. It is of the very essence of absolutism that it is against every principle that will bind itself, and for every advantage that will increase the power of the ruler over the ruled.

Now the underlying conception of the Law of Nations is this : that there are, in this realm of legal relations, no rulers who alone can make the law, and no subjects who are compelled to submit to it. It is a realm in which the jurist seeks to discover what is just; and the nations, after considering whether or not it is so, agree to accept and abide by the results.

It did not take long for independent minds seeking new foundations for the State, to perceive that, underlying this conception of law, there is the basis of a new system of political philosophy, the idea of natural rights; which, from the time of Grotius, had 


\section{INTERNATIONAL LAW AND POLICY}

been given wide publicity as a revival of doctrines fundamental to the Roman Law.

It had not been very distinctly recalled until a foreigner, Professor De Lapradelle, reminded us that from 1758 to 1776 , when American political conceptions were in process of formation, the great jurists who wrote of Natural Law as the basis of the Law of Nations, such as Grotius, Pufendorf, and Burlamaqui, "were read, studied, and commented upon in the English colonies of America." As early as 1773, the Law of Nations was taught in King's College (now Columbia University), and "in 1774 Adams, and in 1775 Hamilton, quote or praise Grotius and Pufendorf."

A very considerable influence appears to have been exercised upon our revolutionary fathers by the Swiss jurist, Vattel, whose work on "The Law of Nations or the Principles of Natural Law" was inspired by a spirit of political liberalism, that was without precedent. No previous writer had ventured to class a sovereign as a criminal, but Vattel had the courage to write: 


\section{PROBLEMS IN FOREIGN POLICY}

"If then there should be found a restless and unprincipled Nation, ever ready to do harm to others, to thwart their purposes, to stir up civil strife among their citizens, there is no doubt but that all the others would have the right to unite together to discipline it, and even to disable it from doing further harm."

Not hesitating to place such nations in the criminal class, he does not shrink from applying to them the rigors of the criminal law. "They should be regarded," he says, "as enemies of the human race, just as in civil society persons who follow murder and arson as a profession commit a crime not only against the individuals who are victims of their lawlessness, but against the State, of which they are the declared enemies." And, in closing his paragraph with the recommendation of punishment, he adds, "Of that character are the various German tribes of whom Tacitus speaks."

Three copies of Vattel's book, brought out in a new edition specially adapted for America, in 1775, by Dumas, a Swiss re78 


\section{INTERNATIONAL LAW AND POLICY}

publican resident in Holland, were sent to Franklin; who, in acknowledging it, says: "It came to us in good season, when the circumstances of a rising State make it necessary frequently to consult the Law of Nations." One copy was sent to Harvard College, another was deposited with the Library Company of Philadelphia, and of Franklin's own copy he says, "it has been continually in the hands of the members of our Congress now sitting."

States, according to this teaching, are subject to the principles of "right reason," supplemented by compacts freely made between them. Thus, in the minds of the colonial statesmen of America, in connection with the Common Law they had brought from England, law, in its political sense, came to be identified with covenants of peoples or covenants of States, freely entered into, in a manner explicit or implicit. Constitutions, statutes, and treaties had, in their view, the same ultimate authority, the rights of man: Constitutions as concessions to the necessity of government, which they limited 


\section{PROBLEMS IN FOREIGN POLICY}

and defined; statutes as concessions to the necessity of civil order, within the limits of ordained government; and treaties as concessions to the necessity of coexistence, harmony, and safety, between independent States.

Quite logically, for the first time in history, they wrote into the Federal Constitution the remarkable words: "This Constitution and the Laws of the United States which shall be made in pursuance thereof; and all Treaties made or which shall be made, under the Authority of the United States, shall be the Supreme Law of the Land; and the Judges in every State shall be bound thereby, anything in the Constitution or Laws of any State to the contrary notwithstanding." (Article VI.)

I have referred to these as "remarkable words," because they not only recognize in treaties the quality of legal perfection, but actually incorporate the covenants entered into by the United States as constituting equally with the Constitution itself, "the Supreme Law of the Land." 


\section{INTERNATIONAL LAW AND POLICY}

In this the action of the United States stands alone, the highest tribute ever paid to the authority of law.

In this country there has never been any doubt that international morality is binding upon sovereign States; but not in a strictly legal sense. Nor is it possible to consider as law, in its proper meaning, those usages which are not in harmony with the social standards and necessities of the present age. In so far as these elements in the Law of Nations are antiquated or without the authority created by consent, the fields of activity they cover need to be provided for in a new fashion, namely, by duly considered special agreements.

It is, therefore, necessary to place emphasis upon the other element in the Law of Nations, which is incontestably not only perfect law, according to the most severe criteria of legality, but the most perfect example of lawmaking in the whole broad field of legislation. I refer, of course, to treaties and conventions, freely and deliberately ne- 


\section{PROBLEMS IN FOREIGN POLICY}

gotiated and ratified by a constitutionally authorized legislative body.

It is impossible, in view of the modern methods of lawmaking, any longer to accept the idea of law expressed in the classic definition of the distinguished English jurist, John Austin, who defines law, as "The commands issued by a sovereign authority to persons in general subjection to it"; which is a description of law in an order of things that has, for the most part, passed away.

Under such a definition, there could, of course, be no place for International Law, - a law created between sovereign States for their mutual governance; nor could there be law of any kind, in the modern legislative sense, for any self-governing people. Where may we look for a "sovereign authority" that can issue "commands" to sovereign States?

Such an authority would be a superstate, a new entity, holding formerly sovereign States "in general subjection to it."

And yet, sovereign States, which do not, and cannot, subordinate themselves without self-extinction, to a supernational authority, 82 


\section{INTERNATIONAL LAW AND POLICY}

do and must create law for the regulation of their own conduct toward one another,a law not imposed from above, but created by themselves, valid and binding between them;-in strict and literal expression, a law international.

It would, I think, not be an error to say, that International Law, when made by general treaties, illustrates the perfection of the law-making process; because it is the result of a mode of procedure in which there is a complete substitution of agreement for command. If it is true, that government by the consent of the governed is the highest political ideal; then the agreements of parliaments, congresses, councils, and legislatures representing the people are the highest type of law; and, indisputably, international treaties and conventions, ratified reciprocally by legislative bodies, are the most perfect examples of this type. They possess an ideal authority which no other form of law can surpass.

Under this system, a great body of positive law, freely and deliberately agreed 


\section{PROBLEMS IN FOREIGN POLICY}

upon, and to a great extent with the added quality of unanimity, has been written into treaties and conventions solemnly and duly ratified, according to the laws of each signatory Power.

In the development of this procedure, the United States has been a leader, because it has introduced the participation of a representative legislative body in the treaty-making process. The law-making treaties of the United States are of their very essence examples of positive law, not only because treaties are declared by the Constitution to be "the Supreme Law of the Land," but because they require the specific approval of the highest legislative branch of the Government.

Originally, before the adoption of the Constitution, under the Articles of Confederation, the making of treaties was the duty of the Congress; but, being feeble as an executive, Congress found itself confronted with the more difficult task of making them respected. In 1786, Washington, in a private letter, wrote to Jay, the accusation that 84 


\section{INTERNATIONAL LAW AND POLICY}

the legislatures of the States were violating the treaty of peace with Great Britain "was greeted by them with laughter." The States had not all developed the sense of national responsibility; but national responsibility was the imperative need, if the Union was to endure, and that is what was created by the provisions of the Constitution in the Convention of $\mathbf{1 7 8 7}$.

In a letter written by Jay to the States of the Confederation, on April 13, 1787, and approved by the Congress, it was declared: "Contracts between nations, like contracts between individuals, should be faithfully executed, even though the sword in the one case and the law in the other did not compel it. Honest nations, like honest men, require no restraint to do justice; and though impunity and the necessity of affairs may sometimes afford temptations to pare down contracts to the measure of convenience, yet it is never done but at the expense of that esteem, and confidence, and credit which are of infinitely more worth than all the momen- 


\section{PROBLEMS IN FOREIGN POLICY}

tary advantages which such expedients can extort."

In this spirit was the constitutional provision made, that the engagements of treaties and the rules of action to which they pledged the signatories, should, in the United States, at least, themselves possess the quality of being the supreme law of the land.

As Mr. Chief Justice Marshall afterward stated, speaking for the Supreme Court of the United States: "A treaty is to be regarded in Courts of Justice as equivalent to an act of the legislature, whenever it operates of itself, without the aid of any legislative provision." And, indeed, the making of treaties very narrowly escaped remaining, under the Constitution, what it had been under the Confederation, an act entrusted to the legislative branch alone. It was only toward the end of the sessions that the previous method was modified.

"It was evident," says Farrand, in his "Framing of the Constitution," "that the convention was growing tired. The committee had recommended that the power of ap86 


\section{INTERNATIONAL LAW AND POLICY}

pointment and the making of treaties be taken from the Senate and vested in the President, by and with the advice and consent of the Senate. With surprising unanimity and surprisingly little debate," he adds, "these important changes were agreed to."

By this division of the process of treatymaking, the Executive was, in effect, charged with the duty of recommending legislation which he might find desirable and practicable, but upon which a truly legislative seal was to be placed only by and with the advice and consent of a law-making body.

Regarding the motives for this decision, Alexander Hamilton wrote, in "The Federalist": "However proper and safe it may be in governments where the executive magistrate is an hereditary monarch, to commit to him the entire power of making treaties, it would be utterly unsafe and improper to entrust that power to an elective magistrate of four years' duration. ... The history of human conduct does not warrant that exalted opinion of human virtue which would 


\section{PROBLEMS IN FOREIGN POLICY}

make it wise in a nation to commit interests of so delicate and momentous a kind, as those which concern its intercourse with the rest of the world, to the sole disposal of a magistrate created and circumstanced as would be the President of the United States.

"To have entrusted the power of making treaties to the Senate alone," he continues, "would have been to relinquish the benefits of the constitutional agency of the President in the conduct of foreign negotiations. . . . Though it would be imprudent to confide in him solely so important a trust, yet it cannot be doubted that his participation would materially add to the safety of the society. It must indeed be clear to a demonstration that the joint possession of the power in question, by the President and Senate, would afford a greater prospect of security than the separate possession of it by either of them."

The judgment of American statesmen and the results of experience have confirmed the view expressed by Hamilton. It has been the custom of the Executive, in matters of 88 


\section{INTERNATIONAL LAW AND POLICY}

large import to avail itself of "the advice and consent of the Senate," at all stages of negotiation; and, in fact, the need of negotiations on particular subjects has sometimes been first brought to the attention of the Executive by the legislative branch of the government. Much of this exchange of views is not, however, a matter of record; for it has been in great part oral, and the nature of the questions under discussion often render these private conversations too delicate to be given publicity when opinion on all sides was still merely in a state of formation by the competent participants.

It is, however, a notable fact that the traditions of the Senate have always been tenacious regarding the responsibility which the Constitution places upon it, and justly so; for, if treaties are not merely executive engagements, and in reality are both supreme law binding upon the nation and destined to affect and to modify, to its benefit or to its injury, the whole fabric of International Law, such engagements become the most solemn transactions which it is the duty of 


\section{PROBLEMS IN FOREIGN POLICY}

a government to perform. As it is the function of the Congress to judge of the causes for which, and the occasions when, it may be necessary to declare war, it is not unreasonable that one branch of it, at least, should interest itself in the conditions which may determine the vital questions of future peace; and nothing is so closely connected with the possibilities of war and peace as the engagements into which nations mutually enter by formal treaties. Involving, as they do, pledges of action as well as pledges of abstention, they may easily contain, under the smoothest and most peaceful forms of expression, the most pestilent seeds of future discord.

In the year 1899, and again in 1907, an opportunity was afforded, at the two Hague Conferences, to perform a large task in improving International Law by law-making treaties.

The results were less than had been hoped for, but they marked an advance upon anything that had before been attempted. Notwithstanding the efforts made by Germany 


\section{INTERNATIONAL LAW AND POLICY}

and her allies to prevent any general understanding based on the authority of law, an important corpus juris of an international character had been brought into existence, which even the obstructive Powers had, under the pressure of public opinion, found it expedient to accept, and had solemnly given their pledges to observe.

It was no outworn and obsolete rules of conduct, but laws as authoritative as human ingenuity can devise that have been openly, shamelessly and brutally violated by nations claiming to rank among the most highly cultivated of modern peoples. By our constitutional provision, these laws, embodied in a series of treaties duly ratified and proclaimed, were not only laws to which we had subscribed, they were an integral part of the supreme law of the United States.

I bring no accusation of negligence; but I do not hesitate to say, that an immediate and earnest protest against the first violation of these laws was not only justified, but a duty which this nation owed to the dignity of the law itself. 


\section{PROBLEMS IN FOREIGN POLICY}

I submit, that there has been no question before the delegates of the Powers victorious in the Great War assembled in Paris to conclude a world peace that compares in import and consequence to mankind with the issue: What, in the future, is to be the authority of International Law? To what end are new geographic boundaries to be drawn on the map of Europe and of the world, oppressed nations to be endowed with a right of self-determination which needs to be guaranteed by others, territories restored to their rightful national connection by a treaty of peace, and partial reparation made for reparable damages inflicted, if International Law is to be left without permanent defense?

This then is the fundamental issue of the hour. The whole edifice of law is menaced, not merely in its superstructure, but at its foundations; for, in the modern conception of it, it is not a system of regulations imposed from above, and always and everywhere enforced by the physical power of the stronger against the will of the weaker; but 


\section{INTERNATIONAL LAW AND POLICY}

a system arrived at by the voluntary consent, and maintained by the voluntary support of those who believe in the essential dignity and authority of law.

What then is to be done to maintain that authority?

Up to this point, I believe, I have said only that upon which we can all substantially agree. But when we come to methods of sustaining the law we leave the domain of law in its proper sense and pass into the realm of policy; which is, to a certain degree, a field of theory.

Here I shall not presume to enter, either to construct or to destroy the fabrics of the mind. My firm conviction is that we shall do well to avoid the magical charm of phrases and catchwords, and to fix our attention upon realities.

The authority of International Law rests on national character. We cannot change that by forming new partnerships, and particularly not by receiving into them a doubtful member, in the hope of rendering the defaulter and the embezzler an honest man by 


\section{PROBLEMS IN FOREIGN POLICY}

giving him an interest in a business for which we are to furnish the most of the capital.

I profoundly distrust the professions and the plausibilities of death-bed repentances, even among nations; and also the improvements of society which result from merely emotional impulses. If we are to build wisely, we shall build on the foundations of tested knowledge and experience. We shall put no trust in any "scrap of paper," no matter with what pious phraseology it may be inscribed, except in so far as we know that there are both strength and character behind it. We went into this war a free people. Let us come out of it a free people. Men talk glibly of world federation. What does it mean? It means, if it signifies anything, that this nation, with other nations, is to place itself under some kind of a central authority, with power to raise and expend taxes, to organize and command armies, to regulate the trade and commerce of the world, and upon occasion to declare war, powers which, under our National Constitution-the most far-seeing document of government ever 94 


\section{INTERNATIONAL LAW AND POLICY}

written by the hand of man-are placed solely in the control of the responsible representatives of the people of the United States. Those powers will, I believe, never be transferred to a new nation, of which the United States would be only a parochial part; nor will they ever be subject to being overruled by the decisions of any association whatever, without the free consent of our own law-making bodies.

We have, during the war, put to the test the strength of our free institutions, and we have found them adequate for war as well as for peace. They have been adequate, because we have never for a moment lost the conviction that we are a free people, and that we were acting in perfect freedom. Had the matter of our food been under the control of a supernational body, had our young men been ordered by an authority not American to leave their business and report for conscription to cross the sea and fight at the dictation and in the interest of a foreign people, had the occasion called for action that was in any degree doubtful to the American con- 


\section{PROBLEMS IN FOREIGN POLICY}

science, this people would not have made the sacrifices of life and treasure which they have gladly made with unreluctant consecration of mind and body.

There is a limit to national, as there is to personal responsibility. Nationally, that limit is defined by the maintenance and vindication of law. I fear the imperial sodality of Great Powers associated for any other purpose. No condominium has ever been free from jealousies and friction. Even so trifling a partnership as the control of the Samoan Islands was a thorn in the side of three nations until it was dissolved. Every such condominium has ended either in quarrel or partition, or in both; and the net result is always merely deferred annexation. A partnership for equal economic opportunities among unequal nations offers the prospect of unexpected demands; which, if not granted, will lead to the accusation of bad faith.

How then can we find a modus vivendi for sovereign States? How, indeed, if not in a united support of law, the recognition of 96 


\section{INTERNATIONAL LAW AND POLICY}

their equal freedom, and their mutual obligations? Law does not require a renunciation of rights; it affirms, guarantees and protects them. That is its very purpose and its whole significance.

Let there be then a union for the maintenance of the law. Such a union now happily exists. It consists of the nations that have had the force and the courage to enter the war, in order to bring the law-breakers to justice, and of no others. I say of no others, because a nation is of value in providing a real sanction to the authority of law only when it is ready to defend the law. A neutral nation at best only renders a passive respect to the authority of the Law of Nations. In the cause of equity it is not an asset, it is only a liability.

I, of course, do not overlook the fact that the prevention of war is of great interest to neutrals, for they are necessarily involved in its hardships by the restriction of their trade. In a speech delivered by the late Lord Parker, a short time before his death, he predicted that, if in future it were made 


\section{PROBLEMS IN FOREIGN POLICY}

clear that there could be no neutrality, the danger of war would be minimized, because its risks would be increased. Then all nations would be more anxious to prevent it, in so far as it is in their power to do so. Mediation would be a necessary act of selfpreservation; and for this there is full justification. There is an old English form of indictment, I am told, that bases arrest on the violation of "the peace and dignity of the King." There may well be a form of international indictment against those who would disturb the peace and dignity of mankind.

For my own part, speaking now as a realist, I look for the prevention of war chiefly to the command of the sea. I do not rest my faith on "the freedom of the sea"-we have seen what that may mean-but on the law of the sea; and that law should be simply the principle set up in opposition to the unlimited right of war, namely, the inviolability of the innocent, for which the Entente Allies have been fighting.

On the 20th of November, 1918, the culprit fleet of Germany-in the presence of 98 
British, American, and French warshipscoming forth from its lair, marshaled by the British light cruiser Cardiff, swept across the North Sea through the morning mist in gloomy procession, to be shepherded into captivity. "Ignominious and yet magnificent," as a writer describes them, the Seydlitz, the Moltke, the Derfflinger, the Hindenburg, and the Von der Tann, boastful battle cruisers, the pride of the German Emperor, that had long celebrated "The Day" when commanding the empire of the sea they could bring the world into subjection, swept through the mist, followed by the nine battleships, then the fifty destroyers and the great flotilla of guilty submarines. "It's a fine sight," a sailor exclaimed, "but I wouldn't be on one of those ships for all the world."

Unconsciously, this lad felt in his heart what every true sailor hopes will be the future law of the sea. It was on the sea that International Law had its birth in the old sea codes, the "Table of Amalfi," the "Consolato," the "Jugemens d'Oléron," and 99 


\section{PROBLEMS IN FOREIGN POLICY}

the "Laws of Wisby," which made the sea, because it is the highway of the world, a place where above all others the rights of man should be respected and maintained. Brave to battle with wind, and wave, and storm, the true sailor scorns a Power that would add to the struggle with nature the inhumanity of man. The sea is the realm of humanity's defense. Closed by the will of all civilized peoples to the greed of the pirate, the united navies of the Entente must make its law the inviolability of the innocent. And this can be done.

If the Entente Allies, who have fought together in this war to vindicate the rights of nations, are not to be trusted, and there is in them no soul of honor, then the outlook for mankind is, indeed, a hopeless one. But if they can be trusted in so great a matter, the formula for the defense of right is very simple.

I take a leaf from the diplomatic correspondence of the British Secretary of State for Foreign Affairs, then Sir Edward, now Viscount Grey. 


\section{INTERNATIONAL LAW AND FGLICY}

Writing to M. Paul Cambon, French Ambassador in London, on November 22nd, 1912, he said: "You have pointed out that, if either Government had grave reason to expect an unprovoked attack by a third Power, or something that threatened the general peace, it might become essential to know whether it could in that event depend upon the armed assistance of the other. I agree that, if either Government had grave reason to expect an unprovoked attack by a third Power, or something that threatened the general peace, it should immediately discuss with the other whether both Governments should act together to prevent aggression and to preserve peace, and, if so, what measures they would be prepared to take in common."

This understanding was a menace to no honorable nation. It was, in fact, one in which all honorable governments might join. It suppressed no one's freedom; it looked toward peace, and not toward war; and it has saved Europe!

A more inclusive formula might possess 101 


\section{PROBLIMS IN FOREIGN POLICY}

the same qualities and serve the same purpose. It might read: "We, the signatories, agree that, if peace should be anywhere threatened, we will together inquire into the cause of aggression; and if we find that the Law of Nations has been anywhere violated, we will by mediation together use our best endeavors to avoid strife. If war is begun, we will together consider what measures we should take in common. And we mutually agree to submit any difference we may have with one another or with other nations to a like mediation. To this end we continue our close association of intimate counsel, and will receive into our understanding other governments when circumstances may render it proper to do so."

To many minds this may seem too attenuated, too much dependent upon good will and a common purpose. To that I have only to say this. Without good will and without a community of purpose there is no agreement and there is no sure keeping of engagements among men. Underlying all human endeavor and coöperation, the strong102 


\section{INTERNATIONAL LAW AND POLICY}

est motive is a love of freedom. Unless they are forced to yield to some type of imperialism-personal, national, or multiformwhich they will never cease to resent, men who believe that there is no true government that is not founded upon the consent of the governed, will not consider themselves bound, even by the authority of the law, if they discover that by its mandates they are no longer free. 


\section{IV}

THE CORPORATE CHARACTER OF THE

LEAGUE OF NATIONS

IF language is to have any exact meaning, it cannot be pretended that a League of Nations can be identified with the entire Society of States. Sovereign States, under the Law of Nations as it exists, are equal before the law, regardless of their military power, physical magnitude, or economic importance. They are to be treated under International Law as legal persons, possessing rights inherent in their sovereignty, which all civilized nations are bound to respect.

The work in which the Conference at Paris has been engaged is not, properly speaking, the formation of a universal Society of States, such as that contemplated by International Law, but the creation of a 104 


\section{CHARACTER OF LEAGUE OF NATIONS}

predominant group within this more general association. ${ }^{1}$

In the minds of those who are the most active in commending this League, there is apparently no very precise conception of its real nature. They have spoken alternately of a "Treaty," of a "Covenant," and of a "Constitution," without making any distinction between them, or seeming to realize that this is a matter of the least importance. To them it is an agreement to end war; and they appeal for support on this ground, with little regard to the obligations involved or the ultimate consequences which may follow from accepting them.

When it is pointed out that participation in this League, in the form proposed, might prove disadvantageous to the United States, some of its advocates reply, "After all, it is only a treaty, and a treaty can be abrogated at any time."

This assumption is based on the statement in the Constitution of the United States,

${ }^{1}$ The original and the final forms of the "Covenant" are printed in full at the end of this volume. 


\section{PROBLEMS IN FOREIGN POLICY}

that "All treaties made, or which shall be made, under the authority of the United States, shall be the supreme law of the land." Being a law, it is contended, a treaty may be nullified by any subsequent law which contradicts its provisions or prevents the execution of them; and such a law it is always within the power of Congress to enact.

If this were the nature of treaties made by the United States of America with other nations, it would be difficult to find any others that would care to enter into treaty relations with the United States. By asserting it, we should put ourselves on a lower level of ignominy and dishonor than that which Germany has occupied, and which we have denounced with bitter scorn; for we should be, in effect, declaring that we regard a solemn compact as "a scrap of paper," not because of changed circumstances or national necessities, but because it was intended that it might be nullified even before it was signed.

A treaty, even the least important, is something more than a law; it is a contract. 


\section{CHARACTER OF LEAGUE OF NATIONS}

However the legal effect of such a document might be changed, as a contract it is not affected by a change in the law; and it cannot be denounced, except by its own specified termination or the consent of the other contractants, without incurring the hostility of those who insist upon the fulfilment of its obligations. The only remedy for this default is war, and the non-performance of the obligations of the contract is a legitimate casus belli.

It may, indeed, be said that there have been instances of failure to keep treaty engagements, which have been nullified either by the refusal to pass the laws necessary to the execution of the treaty, or by the enactment of legislation forbidding the acts which it requires. But the United States has never done this in the case of any Great Power able to enforce the obligation thus repudiated. It would have been a simple matter, for example, to pass the necessary legislation and proceed to the building of an isthmian canal, regardless of the famous Clayton-Bulwer treaty with Great Britain. It was, however, 


\section{PROBLEMS IN FOREIGN POLICY}

never claimed that an act of legislation by the Congress of the United States could absolve this country from the embarrassing obligations of that treaty; although it could have been argued that it was already invalidated by acts performed by Great Britain. But so long as those arguments were not accepted by the other contractant, it was necessary to admit that a denunciation of the treaty would have been a breach of faith and even a casus belli had Great Britain chosen to consider it in that sense. It is futile, therefore, to maintain that treaties may be abrogated by a unilateral legislative act.

It may be said of the proposed League of Nations, although the word Constitution is now omitted, that it is much more than a mere treaty involving mutual obligations. It is spoken of as a "Covenant," but it is much more than an assemblage of reciprocal promises. If the League were a mere pledge to do or not to do certain things, it would never have seemed to require a "Constitution," which implies the creation of a new entity, something which can perform certain 108 


\section{CHARACTER OF LEAGUE OF NATIONS}

actions by itself; and, beyond all possible contradiction, this League is such an entity, and is endowed with powers of immense consequence which prior to its creation have never had a legalized existence.

Perhaps the most important of all the considerations thus far emphasized by those who have discussed this project of a League is the legal interpretation of the original form of this document made by Mr. Justice Stafford, of the Supreme Court of the District of Columbia, in his discriminating analysis. He finds it to be not merely a treaty of alliance or agreement to preserve peace, but the creation of a corporate entity possessing not only advisory but strictly governmental powers. He considers that these powers may come into conflict with those of the separate governments that enter into the League. That is a question which I shall not discuss at this time; but I shall undertake to show that the League, even in its revised form, as a distinct corporate entity, exercising a will not identical with that of all the separate members, is organized with power to coerce 


\section{PROBLEMS IN FOREIGN POLICY}

other States not belonging to it, to act under its own rules and by its own judgment, and even to dictate the form of government and degree of authority to be exercised over wide areas and great populations subjected to its control. Whatever ambiguities this document may contain - and they are many - upon these subjects it is unequivocal.

If the League were based merely on a "Covenant," the mutual agreements would be the whole substance of the document. But this is by no means the case. The League of Nations, as here planned, is not a federation, in which the component States are combined into a new political organism. It is an autonomous corporation, endowed with its own organs of action. Its being and its powers, when once constituted, would persist if a great part of the constituents should perish.

A mere agreement between sovereign States for their mutual defense, like that in Article X, requires no such organic law. An agreement implies merely an assent, an association, or a partnership of persons, natural 


\section{CHARACTER OF LEAGUE OF NATIONS}

or legal, for certain specified purposes, which may terminate when its ends have been accomplished by the performance of certain definite acts on the part of the contractants thus making the agreement. This so-called Covenant is not such an agreement or partnership. It creates a new legal person, acting by itself in a manner to be determined by itself, and in accordance with rules to be adopted by itself. It creates a body, at first called the Executive Council, which, in turn, chooses and directs its own organs of action, defines their rights and duties, and confers new authority upon them. It creates obligations on the part of the nations composing the League which these nations owe not to one another but to the League, as a distinct and separate legal person, who can call them to account for non-performance of duty and inflict punishment upon them. It attributes to the League as a corporate entity, powers which, under International Law, the separate States do not, either singly or in combination, themselves possess; thus creating an imperium over States not belonging to the 


\section{PROBLEMS IN FOREIGN POLICY}

League, which is empowered to coerce and punish them for not submitting to its decisions. The duties of the officers of the League are duties to the League, not to the component States, which cannot separately hold them to accountability or punish them for excesses or disobedience. The League is empowered to govern through its mandataries certain colonies and territories acquired by conquest. These mandataries are required to exercise their authority, which is derived entirely from the League, as explicitly directed by the Council in a special "Act or Charter"; which is, in effect, a royal prerogative, such as that which the Kings of England exercised in granting colonial charters in America. ${ }^{2}$

From this enumeration of powers it is evident that the League created by this Constitution is not merely a corporate entity but in effect a super-government. If a sovereign State, cited to appear as provided under Article XVII, should refuse the "invitation,"

${ }^{2}$ The words of the original draft. The words are omitted in the revision, but the intention is not changed. See Article XXII, next to last paragraph. 


\section{CHARACTER OF LEAGUE OF NATIONS}

and commit a breach of Article XII, all the provisions of Article XVI would become applicable to it. All the members of the League would then be in a state of war with the offending State. If it continued to be refractory, and refused to yield its independence by submitting to the decision of the Executive Council, the League would make war upon it. If the result should be subjugation and conquest, the occasion would arise for designating a mandatary; and the imperium of the League would thus be imposed upon the conquered State. That a defenseless State would probably prefer obedience to conquest does not in the least modify the imperial character of the League.

When we pass from the general nature of the League of Nations to examine more closely the extent and character of the powers possessed by the League, as a corporate entity, it is evident that, if these powers are real and become operative, and are not merely advisory or minatory, they derogate materially from the independence and sovereignty of the States composing the 113 


\section{PROBLEMS IN FOREIGN POLICY}

League. If, on the other hand, these powers are not real and operative, but merely advisory, then the League possesses only an apparent but altogether illusory authority.

The ambiguity of this document, as originally worded, whether called a "Covenant" or a "Constitution," is generally admitted. It has received from persons supposed to be competent diametrically opposite interpretations, and such conflicting views have been expressed even by the same person, at different times, and upon different occasions.

More precision is still necessary regarding the exact force of the expression "recommend." When so serious a matter as the punishment or compulsion of a refractory State comes up for action, the Council is to "recommend" what effective military or naval force the members of the League shall severally contribute to the armed forces to be used to protect the Covenant of the League (Article XVI).

Is it conceivable that such a contribution, thus demanded, can honorably be refused? To what purpose, then, is the recommenda114 


\section{CHARACTER OF LEAGUE OF NATIONS}

tion made, or authorized? Such a refusal would have two effects: it would produce among members a general condemnation of the delinquent Power for failure to support the League; and it would render the Executive Council derisory as an organ of executive action. No self-respecting man would long consent to retain an office of such responsibility when its purpose was thus treated with contempt and left ineffective.

We must assume, therefore, that, while terms of courtesy are employed in this document, that the "recommendations" of the Council are to be respected; and that no obstacles of the nature of mere expense, inconvenience, or national preference are to be placed in the way of their prompt and effective execution. It should, then, be clearly understood that this virtually terminates the independent foreign policy of the separate members of the League, and places the guidance and control of strictly foreign affairs in the hands of a Council, in which the United States has but a single voice, and we do not know what voice it may be, while there are 


\section{PROBLEMS IN FOREIGN POLICY}

eight others that may assent or oppose. If decisions were made by a majority, the American member might be at any time overruled. If they are to be made by unanimity, as for most cases is now proposed, he could prevent undesirable action; but the League could seldom hope to arrive at any positive conclusion, and the liberum veto would virtually paralyze all policy whatever.

We are here confronted with the question, whether or not the League, as finally proposed, offers any promise of being really effective. Between free self-governing nations on the one hand and a super-government on the other, there is no intermediate condition, no third alternative. It is a case of what the logicians call "excluded middle." It is a choice between "free" and "not-free."

There is, no doubt, a possible case of international understanding which does not involve this dilemma. A declaration of principles, with a solemn pledge to support them, does not necessarily create a super-government, and would leave the nations making 


\section{CHARACTER OF LEAGUE OF NATIONS}

the declaration free. But there is in this Covenant no such declaration. The determination to treat persistently turbulent or aggressive States as public enemies, and to declare that they should be suppressed, would involve no limitation of national freedom. An agreement between nations to arbitrate justiciable differences, not to make war upon one another without cause, and to submit what they believe to be just causes to examination and mediation, would involve no alienation of sovereignty. A combination of all these "covenants," if one chooses to call them by this name, would be a durable and effective "Entente of Free Nations"; that is, a mutual understanding and agreement that certain principles are to be sacredly respected and defended, leaving the decision of the manner of action to the participants, in view of the circumstances that may arise.

As between the actual co-belligerents of the existing Entente, such a covenant is possible and desirable; and the proof of it is that it has freely come into existence, has won the war, and is capable of making peace. There 


\section{PROBLEMS IN FOREIGN POLICY}

can, therefore, be no doubt regarding its effectiveness. It was conceived in freedom, and it should be perpetuated with honor.

It may be said-indeed, it is sometimes insisted upon-that an Entente of Free Nations is precisely what the League is intended to be. It is impossible to give the Covenant of the League of Nations this interpretation. The League professes to bind its members to united action, and it is in the next breath pretended that there is nothing binding about it! The choice must be made, and it is important that it should be clearly understood. Does the League invite, or does it command? If it only invites, it is not a League. If it commands, it is a super-government.

If it is not a super-government, if the Executive Council cannot bring an army into the field to enforce its decisions, the provisions of this Covenant create enormous risks and positive dangers. Although it is one of the alleged objects of this League to prevent war, war is not only distinctly provided for, but the occasions when it must occur are 


\section{CHARACTER OF LEAGUE OF NATIONS}

plainly indicated and are even rendered necessary. Suppose one of these occasions to arise, which may easily happen through a misunderstanding or even a misrepresentation, when another procedure might avert it; having foreordained the war by prescription, having defined the circumstances in which it must occur, what becomes of the League if the recommendation of the Excutive Council is not promptly and effectively followed?

The truth is, if the conditions in which military action, or even economic action, will be. unitedly undertaken are distinctly prescribed beforehand, when that action is called for it must be taken, or the whole plan is ridiculous. The same cannot be said of an Entente, which lays down certain principles which it agrees to support and maintain. It does not say that, in such and such conditions, it will act thus and so. It says, We stand for the arbitration of justiciable disputes, for International Law as a standard of conduct, for a court of justice, for conciliation and mediation, and we shall both re- 


\section{PROBLEMS IN FOREIGN POLICY}

spect and support these purposes. If you make war and disregard the rights of humanity, we are against you. We do not tell you now what we shall do; but we shall do what we think right, as we have in the Great War. You may judge for yourself whether you want the United States on your side. We are with all of you, so long as you live according to law; but we shall stand for the law.

No one can carefully examine this Covenant without discerning that it is the work of politicians and not the work of jurists. They have created an organ of power, but not an institution of justice. They have not distinctly recognized any rights, or made any provision for determining them on judicial grounds.

As Mr. Elihu Root has well said of the original draft:

"The scheme practically abandons all effort to promote or maintain anything like a system of International Law or a system of arbitration, or of judicial settlement, through which a nation can assert its legal 


\section{CHARACTER OF LEAGUE OF NATIONS}

rights in lieu of war. It is true that Article XIII mentions arbitration and makes the parties agree that whenever a dispute arises which they recognize to be suitable for submission to arbitration they will submit it to a court 'agreed upon by the parties.' That, however, is merely an agreement to arbitrate when the parties choose to arbitrate, and it is therefore no agreement at all. It puts the whole subject of arbitration back where it was twenty-five years ago.

"Instead of perfecting and putting teeth into the system of arbitration provided for by the Hague Conventions it throws those conventions upon the scrap heap. By covering the ground of arbitration and prescribing a new test of obligation it apparently by virtue of the provisions of Article XXV abrogates all the 200 treaties of arbitration by which the nations of the world have bound themselves with each other to submit to arbitration all questions arising under International Law, or upon the interpretation of treaties.

"It is to be observed that neither the Ex- 


\section{PROBLEMS IN FOREIGN POLICY}

ecutive Council nor the Body of Delegates to whom disputes are to be submitted under Article XV of the agreement is in any sense whatever a judicial body nor an arbitral body. Its function is not to decide upon anybody's right.

"This is a method very admirable for dealing with political questions; but it is wholly unsuited to the determination of questions of right under the Law of Nations."

The attitude of this Covenant, even in its revised form, toward International Law is, indeed, surprising. It nowhere makes reference to it, except briefly in the Preamble; and it does not even there commit itself to the support of it or the improvement of it. It speaks of "understandings of International Law," but it does not admit the authority of International Law as an accepted corpus juris to which civilized nations have already agreed. It does not state whose "understandings" are to be applied, and it does not inform us where or how any "understandings" are to be obtained. It leaves the subject with ground for inference that they are 


\section{CHARACTER OF LEAGUE OF NATIONS}

to be discovered, if at all, only in its own decisions.

In view of the fact that the League as it will be constituted is an exclusive corporation, to which only those it is willing to receive can be admitted, it is evident that by itself it will not be a body competent to make laws. It will probably consist, if it comes into existence, of a minority of the sovereign States of the civilized world. Even if it were a majority it would not be sufficient. It may through its preponderance of power be able to command, and even to enforce its will, but law does not rightly issue from mere power, or rest on power. It can never justly claim obedience merely because it is an expression of somebody's will. It must be the offspring of reason, or it cannot claim to be law in any true juristic sense. It will remain only policy.

There is in the Covenant no provision for a legislative body. Neither the Council nor the Assembly is such a body. They do not claim to be, yet they propose to decide and to enforce their decisions. The Council gives 


\section{PROBLEMS IN FOREIGN POLICY}

or withholds its "permission." It proposes to settle disputes "upon such conditions as the Council may deem just," and to apply its provisions "with such modifications as may be deemed necessary by the League." It even summons other States, not members of the League, having disputes either with members of the League or with States not members of the League, to appear before it, to accept its judgment, and to become subject to the provisions of this Covenant.

In order that my affirmation on this point may not stand alone, I quote the following statement from one of the ablest advocates of the League, whose eminence as a lawyer no one will dispute, Mr. Henry W. Taft. Commenting on Article XVII, he says: "This article is designed to bring to bear upon the States which do not become members of the League the coercive effect of the covenants so as to prevent disputes among them from leading to war. It provides for cases of dispute between a member and a non-member and between States which are non-members. For the sole purpose of the 124 


\section{CHARACTER OF LEAGUE OF NATIONS}

settlement of the dispute, non-members are invited to become members of the League, and upon the acceptance of such invitation an investigation and a recommendation is made by the Executive Council. In case a non-member State refuses to accept the invitation and thus to subject itself to the provisions of Article XII, postponing the commencement of war, the member nations agree to apply to the refusing State the boycott provided for in the first paragraph of Article XVI. Thus the drastic measures of that article will be resorted to for the purpose of preventing war, not alone among members of the League, but also among all the nations of the earth. Article XVII also provides that where two non-members refuse to accept the invitation to assume the obligations of membership for the purposes of the dispute, the Executive Council may take such action and make such recommendations as will prevent hostilities and result in the settlement of the dispute."

By what principles of law does the Council of this League "bring to bear the coercive 125 


\section{PROBLEMS IN FOREIGN POLICY}

effect of the covenants" upon States that do not belong to the League, citing a State to appear before it even before any violation of International Law has been committed?

Nominally, no doubt, it does this in the interest of peace; and I shall not deny that this interest may be so great that the effort to settle a dispute should be made, but this right of coercion by a self-constituted body has no justification in law, as International Law now exists, nor is there here any means proposed to secure the recognition of such coercion as a legal right.

It may, of course, be that the will of the Council of this League will always be a righteous will; but it cannot be denied that, if it is to be exercised in this manner, it is an imperious will. It can be justified only by the assumption that the League possesses an imperium over States outside its membership. It claims a sovereignty that nullifies the sovereignty of the States which it summons for judgment, for it insists that, unless its judgment is accepted, the League will enforce it by war. 


\section{CHARACTER OF LEAGUE OF NATIONS}

A State which is a member of the League -especially a very powerful State-may on romplaint, under this Covenant, bring any other nation into its own court in a dispute of which it is itself the author. Thus a European government might bring a case against the Republic of Cuba, for the recovery of debts dating from the Spanish occupation, in which technically Cuba would be held liable for the payment of securities issued to oppress her people and prevent her independence. If the case were submitted, a European court might justify the claim; at least, I know of jurists who believe it would be thus collectible. Should Cuba be advised to accept a trial in such a case?

In this connection the question inevitably arises, How far would the mere policies of the League become, in its own understanding, identified with International Law, as its Executive Council would apply it? By what code, or rules, or standards of international conduct would this Council render its decisions? If the answer is, by the principles and maxims of International Law at present 


\section{PROBLEMS IN FOREIGN POLICY}

generally accepted, its procedure in citing nations not members of the League, as we have seen, would be illegal. It would, therefore, undoubtedly undertake to alter, and even to create, rules of law. By what authority could a limited number of Powers do this? And what would the attitude of independent sovereign States outside of this League-which would probably for some time, and possibly always, constitute the minority of States-continue to be? Could they accept decisions regarding the principles and maxims of International Law, arbitrarily made by a limited body in which they were wholly without representation?

The policy of the League appears to be that neutrality is to be abolished. That is the assumption underlying the President's abandonment of the "freedom of the seas," and his acceptance of Great Britain's retention of her supremacy at sea, on the ground that when the League comes into being there are to be no neutrals. But who can affirm that there are to be no neutrals? By what right can this League declare that there are no 
neutrals? And if there are neutrals, what is to become of the existing rights of neutrals under International Law? Is neutral territory no longer to be inviolable? Are the armies of the League to march freely against its enemies across neutral territory, without regard to the wishes of neutral States? Are there to be no neutral rights on the sea? What is to happen when the League declares an economic boycott against an offending State? Are all States, even the neutralized, like Switzerland, which desires to retain that status, to be compelled to observe it?

According to International Law as it exists, and is now understood, the rights of neutrals on the sea are definitely recognized. Has any single group of nations, or a league created by them, acting as a corporate entity, the right either morally or in a jural sense, to violate or arbitrarily to abrogate the laws protecting them?

The attitude of Switzerland on this point has been affirmed by the Swiss Confederation in a separate plan for a League of Nations completed in January, 1919. In the sixth 


\section{PROBLEMS IN FOREIGN POLICY}

article it is demanded that the "permanent neutrality" of Switzerland, and also of other States which desire to maintain neutrality, shall continue to be recognized; and it is declared: "The territory of these States is inviolable and shall always remain outside military operations, in case of wars in which States not forming a part of the League of Nations participate, as well as when military measures are taken by members of the League itself, in order to secure respect for law or the maintenance of peace." It is, therefore, obvious that the Swiss Confederation cannot accept the proposed Constitution of the League, if Article XVI retains the clause in which the members agree that "they will take the necessary steps to afford passage through their territory to the forces of any members of the League which are cooperating to protect the covenants of the League." Furthermore, Switzerland declares her intention to protect her territory with force of arms.

The three Scandinavian Kingdoms-Sweden, Denmark and Norway-have also, in 130 


\section{CHARACTER OF LEAGUE OF NATIONS}

January, 1919, prepared a separate project of an "International Juridical Organization," in which a protest is offered against an "international parliament" which would constitute an "authority superior to the States"; and it is declared that the small States, in particular, would offer "energetic opposition," if an attempt were made in an association of this kind following any system whatever implying a "graduated scale" in the classification of States.

The so-called secondary States are evidently resolved to oppose an attempt to deny their right of neutrality or to create International Law without their consent, as this League of Nations may undertake to do.

If this group, or this artificial entity, has the physical strength to do so, it can undoubtedly violate these rights and disregard existing laws; but it would be possible to do so only by force majeure-by the exercise of arbitrary power in defiance of law.

This is imperialism. It may be well-meaning-imperialism always pretends to be benevolent-but if the war in which we have 


\section{PROBLEMS IN FOREIGN POLICY}

participated was a war to destroy imperialism, and to establish the self-determination of free nations under law, which should be the expression of their consent, a plan which merely establishes a composite imperialism, the arbitrary power of a single group of nations, would be not a victory for freedom, but its defeat.

The contention that this Covenant creates an imperium does not rest alone on its attitude toward States outside the League. Under Article XXII the Council undertakes to govern, through its appointed agents, vast areas and numerous populations. It may govern well, or it may govern ill, but it assumes the right to govern.

Whence does the Council derive its right to issue mandates, "according to the stage of the development of the people, the geographic situation of the territory, its economic condition, 3 , and other similar circumstances"? It is true, as it is alleged, that the wishes of these communities, in the case of the Turkish Empire, must be a principal consideration in the selection of the manda- 


\section{CHARACTER OF LEAGUE OF NATIONS}

tory Power; but in the case of those in Africa or in the South Pacific, although certain rights of the population are recognized, and "equal opportunities for the trade and commerce of other members of the League," but not of others, are secured, they fall completely under the sovereignty of the League. Full sovereignty is surrendered to it, and it becomes, as a corporation, a sovereign Power. Or is it possible that this sovereignty is some time in the future to be reclaimed by the separate conquerors? For the present, at least, this sovereignty is so complete that, as the Covenant provides, "The degree of authority, control, or administration to be exercised by the mandatary shall, if not previously agreed upon by the members of the League, be explicitly defined in each case by the Council." 3 Can it be held, in the light of this, that the League, which is perpetual, is not in law a new sovereign and imperial Power? Or must this transfer of power be classed as a wholly lawless proceeding?

'The original text says, "in a special Act or Charter." 133 


\section{PROBLEMS IN FOREIGN POLICY}

We must, no doubt, admit that there are "backward peoples," as they are called. Confessedly, they present a difficult problem to solve. It may be that this is, on the whole, the best solution of it; but the questions of duty and of responsibility arising out of it are very serious, especially for a people bred to consider and respect the love of freedom. We have been forced to accept the "white man's burden" in the Philippines and elsewhere, but we have never rejoiced in the necessity, and we have never approached our task in an imperiai spirit, although we cannot deny that the attempt to rule a subject race involves the exercise of an imperium.

It is, no doubt, better for us as a people that we should never again undertake an imperial partnership. We had a woeful experience in the Samoan Islands, and we were glad to get out of it without involving ourselves, as we came near doing, in a scene of continuous bloodshed brought on by intrigue. As President Cleveland said of our experiment, in a message to Congress: "This incident and the events leading up to it sig- 
nally illustrate the impolicy of entangling alliances with foreign Powers." If any one wishes to know what the responsibilities of a mandatary under the Executive Council of the League might involve, let him read the pathetic story of the disappointment of the Samoans in their civil wars and their descent from the promise of autonomy to the complete deprivation of their rights, as related by Willis Fletcher Johnson in his history of "America's Foreign Relations." "The United States," he writes, in closing the chapter on this subject, "began by abandoning two of its most important principles of foreign policy-that the United States should refrain from intervention in the domestic affairs of other nations, unless in the necessitous emergency of its own self-protection, and that it should avoid entangling alliances with other and particularly European Powers. . . It was guilty of savage cruelties which would have been regarded as monstrous in the least civilized of the Samoans themselves. It was guilty of bad faith to Samoans who trusted it. It failed to win 


\section{PROBLEMS IN FOREIGN POLICY}

for its iniquitous policy the poor vindication of efficiency and success, confessing at the end that it was a wretched failure. And it finally abandoned that policy not because it was wrong, but because it was too costly and troublesome to continue."

And now the Samoans have again been made victims of international strife. Relying upon this infamous precedent of the triple protectorate over Samoa, a distinguished advocate of the League, in order to show that this treaty is within the constitutional power of the United States, cites this Samoan example, saying: "The three signatory nations undertook a guardianship of the islands similar to that which is contemplated in the proposed Covenant of the League with reference to backward countries!"

But, it appears, we are not now to stop with simple islanders. Among our suggested allotments in this program of joint imperialism, in which our participation is expected to justify the perpetuation of the whole colonial system, are Constantinople, 


\section{CHARACTER OF LEAGUE OF NATIONS}

the worst center of racial and diplomatic intrigue in Europe; Armenia, which contains a vast Turkish and Russian population, face to face with Russian Bolshevism, backed by Turkish machinations to regain control, in case it is actually ever taken from the Turk, which has not yet been accomplished; and Persia, which we once tried to help in the person of an American financial administrator, whose work was rendered futile by Russian and, alas! British intervention. Largely because of this, a correspondent of the "Manchester Guardian" considers that Persia should be placed by the League under the United States as a mandatary. "Persia," he says, "can trust America as she can trust no other Power."

But what does he say of the other Powers? "It is obivous," he continues, "that great care will be necessary if the whole of this mandate system is not to become an abuse." "Outwardly," he goes on, "the world has accepted the revolutionary conceptions which underlie President Wilson's scheme"-meaning a League of Nations-"but it has not yet 


\section{PROBLEMS IN FOREIGN POLICY}

emancipated itself from the view that a nation counts in the world by its direct political influence. Nor have we destroyed the spirit that seeks commercial advantages in political expansion."

This candid Englishman frankly lacks confidence in General Smuts' systern of mandataries. "If the mandate system so works in practice that the mandatory Power draws some economic advantages from its position, or if it fastens the hold of the mandatory Power more firmly than ever on the dependent people, then," he says, "we may live to regret the day when our statesmen invented a scheme which has become merely a device for giving a decent look to the bad habits of the past." Knowing that past, this writer does not hesitate to speak of "intrigues to bring about a change of mandate for selfish reasons"; and he considers it "important also to prevent a conspiracy among the mandatory Powers to screen each other from criticism"!

Imperialism is imperialism, whether it be joint or single; and it is not a business that 138 


\section{CHARACTER OF LEAGUE OF NATIONS}

tends toward democracy or toward justice. Even in its purity and at its best estate it is a dangerous enterprise for a free people to engage in, and it is more dangerous than ever when innocence and good intention become the parters of seasoned experience in a game for power. 


\section{V}

THE TREATY-MAKING POWER UNDER THE CONSTITUTION OF THE UNITED STATES

WHEN the United Kingdom of Great Britain and Ireland enters into agreements with foreign nations, it is the King who grants authority. He speaks as a sovereign. The formula of the full powers of his plenipotentiary is: "George, by the Grace of God, of the United Kingdom of Great Britain and Ireland of the Dominions beyond the seas King, Defender of the Faith, Emperor of India. To all and singular to whom these presents come, Greeting."

Full powers to negotiate and conclude a treaty proceed exclusively from the King as a sovereign, who grants authority, as the formula runs, "to sign for Us and in Our name, everything so agreed upon and concluded, . . in as ample manner and form, and with 


\section{THE TREATY-MAKING POWER}

equal force and efficiency, as We Ourselves could do, if personally present."

There is no one in the United States who can thus speak as a sovereign except the whole people, and they have never thus spoken. They have created a National Government, but they have definitely limited its powers; and it possesses none that are not delegated to it in the Constitution of the United States.

There is, therefore, occasion to point out that alliances and compacts affecting the condition and destinies of the European nations, whose laws and traditions entitle a personal sovereign to act, are entered into with more assurance and less reserve, are more customary, and therefore less subject to popular judgment, than is the case in the United States of America; whose Government is not a sovereign, but derives all its powers from the people, who have delegated to it only a partial representation of the sovereign authority which, in this country, the people alone possess.

At the time when our National Govern- 


\section{PROBLEMS IN FOREIGN POLICY}

ment was established, this distinction was well understood and jealously guarded. It was believed by the founders of our Government that they had forever ended the subjection of themselves and their descendants to absolute power. They had revolted against a personal sovereign who was inspired by his absolutist aspirations to overthrow the liberties that had been secured by previous revolution in England, and also against a Parliament in which they were not represented and over which the King had, contrary to the wishes of perhaps a majority of Englishmen, obtained control; and they had resolved that their freedom should never again be thus compromised.

That was the spirit in which the Constitution of the United States was conceived and adopted. During a hundred and thirty years that charter of American liberty, which has since in some degree been an inspiration and a model to every free people, has continued to be the fundamental law upon which legislation and judicial decisions in the United States have been based, and without 142 


\section{THE TREATY-MAKING POWER}

which our Federal Government in all its branches would have no authority.

Since that auspicious solution of the problem of reconciling liberty and government, afterward extended over a wide and diversified area and a highly composite population, in which the offspring of previously hostile races have together found peace and prosperity, many new influences have affected the American people; and some of them have become hostile to the Constitution of the United States, and, indeed, to any fundamental law whatever. Forgetful of the blessings of liberty, some of these hostile groups would prefer a régime of unlimited social reconstruction of their own devising, and are ready for the most radical experiments, even for a return to absolutism under omnipotent governmental control, provided they are permitted to exercise their authority.

A movement even more subversive of the original American conception of government than that which tends toward the establishment of a Socialistic State, but kindred to 


\section{PROBLEMS IN FOREIGN POLICY}

it, is the disposition to repudiate the idea of the nation altogether, and by a wide sweep of inclusion abandon our separate existence as a people, thus merging us with the whole of humanity in some form of vague internationalism.

In practice it is seen that to apply this idea universally is at present impossible. The diversities and the conflicts of races and of stages of development would mean not only the abolition of nations, which are substantial historical achievements in the progress of civilization, but the destruction of civilization itself; as we have seen it illustrated in the disintegration of the Russian Empire, which has reached a stage of complete social anarchy, general impoverishment, and a reign of terror.

It is, on the other hand, sometimes represented that closer federation is the remedy for international strife, and that the union of the American colonies under the present Constitution indicates the path that should be followed to avoid conflicts and preserve 
the peace of the world. The League of Nations, it is urged, would be such a union.

It would be misleading to regard that great act of federation as bearing any analogy to the plan now under consideration. The founding of the Republic of the United States was the establishment of a "more perfect Union" between States contiguous, homogeneous and, in fact, already confederated, possessing a close community of interests and identity of language and political traditions, all sprung from a common mother and long subject to the same sovereign rule. It would be quite a different matter to merge in one corporate existence nations far removed in space, composed of distinct races, diversified in their political institutions, with varied responsibilities, and some of them with unsettled claims upon one another.

We have, however, developed in this hemisphere a group of distinct nations, primarily modeled upon the constitutional system first adopted by the United States. These republics have passed through grave crises and occasional reversion to despotic rule; 


\section{PROBLEMS IN FOREIGN POLICY}

but they have, after bitter experiences, emerged as a system of independent sovereign States, with serious race problems, but with a reasonable vindication of the national and constitutional ideals by which they have been inspired. Taking the American Republics as a whole, they not only constitute a "going concern," but they look forward to a peaceful and prosperous future.

This achievement has been owing to their separation from the hostilities, the intrigues, and the ambitions of the Old World. It has been made possible by the insistence of the United States that they should be left to themselves, and permitted to work out their own development in their own way.

It is true that we have, in the past four years, passed through a deep experience, from which we emerge with new obligations that must be honorably discharged; but it does not follow that our whole theory of national development was wrong. It may be that we shall find an advantage in new understandings and in new associations, the value and character of which the Great War 


\section{THE TREATY-MAKING POWER}

has revealed; but we should not forget that it is our example, and not our interventions, that has been of most benefit to the world. What we have done in the war was done because we were true to ourselves, to our own fellow-citizens whose rights had been cruelly violated, to our own dignity as a nation, and to our own sense of honor. Had we not been a nation, free, unpledged, and strong in our manhood, we should not have been able to perform the part we have performed.

We are now invited to join with other nations with which we have recently been engaged in a common cause, to set up a worldwide, international directorate in which we are called upon to play a new and untried rôle, going forth to regulate the life of distant peoples in a spirit of benevolent joint imperialism. We are urged to transfer our life and activity permanently into another hemisphere, and in compensation to welcome the preponderant influence of others in our own. The only argument for this is that, in spite of the evident contradiction, we may call the new adventure by the old name. In- 


\section{PROBLEMS IN FOREIGN POLICY}

stead of permitting the so-called "new" nations and the tribal groups not yet formed into nations to develop as other nations have done, it is now proposed, through central control by a small group of Great Powers and a retinue of small ones, to exercise an imperium over the whole earth, nominally in the interest of peace, but practically by regarding every local strife as a reason for a general war.

Can the Government of the United States, constituted as it is, participate in such an imperium? Is there in any part of the American Government, or in the whole of it combined, legal authority to enter into a compact of that kind? Has the sovereign of this nation, the People, in whose name the Government has been created, ever authorized it, or ever intended it?

The question has been answered both affirmatively and negatively by men who enjoy the reputation of being competent in questions of constitutional law.

Let us then consider a few propositions 148 


\section{THE TREATY-MAKING POWER}

which, wholly apart from this issue, are not open to debate.

The Government of the United States is a government of delegated powers established by a sovereign people. The Constitution of the United States is the sole charter of that Government. Some of its powers are definitely expressed, others are implied, still others are reserved to the States or to the people. The authority of the Government of the United States is limited (1) by the terms of the power granted; (2) by the purposes for which it is delegated; and (3) by the distribution of power among its respective agents.

If the Government of the United States decides to adopt the Constitution of a League of Nations, it will do so by becoming a signatory to the so-called "Covenant," which it is intended shall be a part of a treaty of peace. 'The right of the Government to enter into this engagement is derived, if it exists, entirely from the treaty-making power delegated to it in the Constitution of the United States. That power is conferred 149 


\section{PROBLEMS IN FOREIGN POLICY}

in the following terms and with the following effect:

"The President shall have power, by and with the advice and consent of the Senate, to make treaties, provided two-thirds of the Senators present concur." (Article II, Section 2, Clause 2.)

"This Constitution, and the laws of the United States which shall be made in pursuance thereof; and all treaties made, or which shall be made, under the authority of the United States, shall be the supreme law of the land." (Article VI, Clause 1.)

The full meaning of these provisions will be better understood when we contrast them with those which prevail in the law and usage of Great Britain, from which the framers of the Constitution intended to depart.

In Great Britain, as has been already stated, treaties are made by the King and in the King's name. In reality, at the present time, they are made by the King's Ministers and not personally by the King, and the Ministers are responsible to the Parliament. In the beginning it was not so. The change 


\section{THE TREATY-MAKING POWER}

has been brought about by a revolt from absolutism in Great Britain as it was in America. In the British system, however, the conclusion of treaties is solely entrusted to the Ministers, and not to any portion of the Parliament as such; but a change is imminent.

In October, 1918, Sir R. Cooper, in the House of Commons, asked the Prime Minister if he intends to take steps to secure that "any agreement for peace shall in general principles be in accordance with the wishes of the majority of the members of this House." Mr. Bonar Law answered: "The Government (meaning the Ministers) must, I think, be the interpreter of the views of the House and the nation in this matter." Sir R. Cooper then inquired, "Is it the fact that the country will be committed to a secret peace compact?" to which Mr. Bonar Law replied that he did not see any way in which the country could be represented except by a referendum unless by the Ministers, thus virtually excluding Parliament from a voice; and this is the historic British attitude on the subject. The reason for it, no doubt, 


\section{PROBLEMS IN FOREIGN POLICY}

is that Great Britain has often entered into secret treaties, and has considered it necessary to preserve this right, which compulsory reference to Parliament would destroy.

In opposition to this established practice, however, the British Premier, Mr. Lloyd George, on February 11, 1919, stated in the House of Commons that, after it was signed at the Peace Conference, the treaty would be placed before the House for ratification, and he added: "If the House of Commons chooses to repudiate the treaty, the House of Commons is all powerful."

Two days later, on February 13, Mr. Bonar Law expressed a different opinion. In reply to Mr. Lambert's question whether or not the British Delegation to the Peace Conference had plenary powers to bind the country, Mr. Law answered: "So far as the British Government is concerned, it will not be ratified until it has been laid upon the table and Parliament has an opportunity of expressing an opinion"; but in answer to a further question, whether or not the treaty of peace would be submitted to Parliament 


\section{THE TREATY-MAKING POWER}

before it was presented to the enemy countries, Mr. Law responded, "Oh, no, I cannot say that. The treaty will presumably, after it has been arranged by the Allies, be signed by the enemy countries."

In this the contemporary British practice indicates an approximation to our constitutional provision by admitting the legislative body to some ultimate coöperation in determining what the terms of a treaty shall be; but it has not reached the stage to which the framers of our Constitution had arrived in the beginning by authorizing the advice and consent of the Senate. If, however, action by the Senate can be had only after a treaty is signed, and then only to accept or reject it, our procedure will have receded toward the conception of absolutism as much as the British has advanced toward parliamentary representation in the treaty-making power.

There is another important difference between the American and the British conception of the treaty-making power. Under the American Constitution a treaty becomes the "supreme law of the land," but only in so 


\section{PROBLEMS IN FOREIGN POLICY}

far as it is of a nature to become a law. As a contract it is not open to judicial interpretation. From that point of view it belongs exclusively to the political department of the Government. When a treaty is self-executing, that is, when it does not require supplementary legislation, it becomes a part of the law of the land, and may be treated as a statute. As Chief Justice Marshall declared, "When the terms of the stipulation import a contract-when either of the parties agrees to perform a particular act-the treaty addresses itself to the political, not the judicial department; and the Legislature must execute the contract before it can become a rule for the court."

In England a treaty does not become the law of the land, and care has to be taken that its stipulations are not contrary to the law; or, if they are so, that the law be amended so that the law and the treaty shall agree. Where the terms of the treaty involve the payment of money, for example, the money is not directly promised, since Parliament alone has the right to appropriate it and the 


\section{THE TREATY-MAKING POWER}

treaty reads: "His Majesty undertakes to recommend to $\mathrm{His}$ Parliament to vote a sum of money." Thus, it is held, no breach of the treaty would result if Parliament should fail to comply with the recommendation.

The question naturally arises-Do the grants of authority contained in the Constitution of the United States authorize the treaty-making power vested in the President, "by and with the advice and consent of the Senate," to enter into every conceivable international arrangement?

It would appear from the fact that all the power possessed by the President and Senate is delegated power, and not power inherent in these officers, that it is limited not only by the terms of its delegation-that is, to be exercised in conjunction-but by the purposes for which it is delegated. It cannot, therefore, be maintained that, merely because the United States is classed as a "sovereign nation," the Government, or any part of it, can therefore perform a sovereign act beyond the scope of the purposes for which it was created, for although the nation is sov- 


\section{PROBLEMS IN FOREIGN POLICY}

ereign, the Government is not. Complete sovereignty resides in the people as a whole, and not in any or all of the public officers.

That this is the correct interpretation of delegated authority under the Constitution is evident from the procedure found necessary for the extension of Congressional power. The Constitution originally qualified the conditions under which direct taxes could be laid. It was necessary to apportion them among the several States according to population. They could not under the Constitution be laid in any other way than that specified, until the power to do so was specifically granted by an amendment.

The treaty-making power, as stated in Article II, is not specifically restricted in the terms of the grant, but there is an implied restriction in the purposes for which the Constitution is framed; for, except as distinctly delegated, all sovereign power is retained by the States and the people. The purposes for which the "more perfect Union" was formed by "the People" are: "to establish justice, insure domestic tranquillity, provide 


\section{THE TREATY-MAKING POWER}

for the common defense, promote the general welfare, and secure the blessings of liberty to ourselves and our posterity." (Preamble.)

All these purposes relate exclusively to the interests of the people of the United States. There is no constitutional provision delegating authority to any part of the Government for any other purposes. If any other purpose had been contemplated, it would have been expressed. There is here no appended et cetera. Indeed, the last clause in this Preamble may be regarded as a perfect summary of all that has preceded, for all are involved in it, namely, "to secure the blessings of liberty to ourselves and our posterity."

For the "common defense," where that is the obvious purpose, alliances with other Powers may, undoubtedly, be made; but it is not apparent that these could be formed for other purposes without exceeding the intentions of the Constitution.

On the other hand, it is evident that no foreign engagements were contemplated, or 


\section{PROBLEMS IN FOREIGN POLICY}

could be regarded as authorized, which in any degree tended to defeat or destroy the affirmative purposes named in the Preamble. Especially might any treaty be regarded as ultra vires, and even violative of the Constitution, if its consequences were to disturb domestic tranquillity, sacrifice the general welfare, or deny the blessings of liberty by imposing on the population, in the interest of a foreign country, any such burden or deprivation as might arouse a spirit of domestic revolt or unrest, except as action might be rendered necessary for the common defense of the people of this country.

An equally peremptory limitation upon the treaty-making power is imposed by the distribution of authority among the different agents of the Government. A treaty is of no value unless it can be executed. The President, "by and with the advice and consent of the Senate," can make many kinds of promises which they would not have the power to fulfil.

It is a part of the theory of our Constitution that there is safety in the distribution ].58 


\section{THE TREATY-MAKING POWER}

of power. In general, every power of government, the legislative, the judioial, and the executive, is to some extent distributed between the Federal Government and the States. In the treaty-making power the States have no part; but, undoubtedly, some of their rights are reserved. As Mr. Elihu Root has said: "The treaty-making power is not distributed; it is all vested in the National Government." This involves an immense responsibility. The President and the Senate act for every citizen throughout the whole country, and if they should pledge the control of the war power to other nations, or involve it in a mechanism that would automatically by prescription draw this nation into foreign wars, their action would affect the fortune and the life of every citizen in a serious manner.

Does any thoughtful person presume to say that the power to do this is an unlimited power? that less than a hundred men are wholly uncontrolled by any legal obligation, and may negotiate and conclude under this treaty-making power any engagement 159 


\section{PROBLEMS IN FOREIGN POLICY}

they may individually please to incur for their fellow-citizens, and for all time?

"It is, of course, conceivable," writes Mr. Root, "that, under pretense of exercising the treaty-making power, the President and Senate might attempt to make provisions regarding matters which are not proper subjects of international agreement, and which would be only a colorable-not a real-exercise of the treaty-making power." There are then matters which are "not proper subjects of international agreement"; but in what manner can we determine what is a "real" and what is only a "colorable" exercise of that power, if not by the purposes for which the "more perfect Union" was formed and the restraints created by the distribution of power among the different organs of the Government?

In most matters the distribution of power is clear and specific; but in the case of the treaty-making power the division between the President and the Senate has given rise to controversy. The evident intention of the Constitution is that the President and the 


\section{THE TREATY-MAKING POWER}

Senate should coöperate in the making of treaties, but the precise manner in which they are to proceed is not defined. Such definition was clearly thought unnecessary, for it could reasonably be presupposed that they would work together in confidence, in a spirit of mutual respect, and with unfailing courtesy and consideration.

No one has ever doubted that the President is the designated medium of communication with foreign governments, and therefore in direct control of the process of negotiation. It falls to him to direct the immediate policy of the country in foreign affairs, and to instruct his diplomatic agents. $\mathrm{He}$ is, therefore, in a position to use his own judgment as to the extent and the manner of taking the "advice" and seeking the "consent" of the Senate. On the other hand, he cannot conclude any treaty without the "consent" of the Senate. Either can completely block the intentions of the other, but neither can force the other; and herein lies the wisdom of the arrangement, for while the President has the initiative and can begin and carry on nego- 


\section{PROBLEMS IN FOREIGN POLICY}

tiations on any subject and with any country, the utility and propriety of his agreements are subject to the judgment of a large body of experienced men, representing varied interests and points of view, and he must convince two-thirds of them that what he proposes is both constitutional and expedient before he can accomplish any final result.

The superior power of the President lies in the fact that he can create conditions which may embarrass the free judgment of his colleagues in exercising the treaty-making power. While they are of various opinions, he can shape circumstances in such a manner as suddenly to confront them with a choice between alternatives neither of which is acceptable to them.

It has been said that the Constitution does not require the President to accept or follow the advice of the Senate; but, on the other hand, it does not require the Senate to approve what the President may finally present to it for ratification. If an impasse is created intentionally, the fault lies with him who has intentionally created it; for it is not 162 


\section{THE TREATY-MAKING POWER}

legally in the power of either participant in the process to destroy the freedom of judgment of the other. The whole purpose of the partnership is that nothing shall be done to which both parties do not freely agree. That is the reason why the making of treaties was not left to the President alone, or assigned to the Congress as under the Confederation. Its safety lies in the fact that it is a joint procedure.

Applying the principle broadly, the contention that one department of the Government may in any way coerce another is a repudiation of the very purpose of the division of power, and would result in the destruction of that freedom under law which the Constitution aims to establish. $\mathrm{I}_{i}^{\circ}$ such an attempt were for any reason successful, it would result in the establishing of an autocratic form of government. Absolutism, which the Constitution was intended to prevent, might thus creep in through the usurpation of power by a single department, or even by a single officer of the Government. There could be no greater offense against the 163 


\section{PROBLEMS IN FOREIGN POLICY}

Constitution than this, and public opinion should unite in condemning even the suggestion of it.

A limitation of equal importance upon the treaty-making power resulting from the distribution of authority arises from the dependence upon Congress as a whole to provide the means for executing the obligations of a treaty. The powers of Congress are very precisely enumerated in the Constitution (Article I, Sections 7 and 8). In any case where war or administration is involved, there can be no execution of a treaty without the action of Congress, which alone has power "to lay and collect taxes, duties, imports and excises, to pay the debts and provide for the general welfare of the United States; to define and punish piracies and felonies committed on the high seas, and offenses against the law of nations; to declare war, grant letters of marque and reprisal, and make rules concerning captures on land and water; to raise and support armies, but no appropriation of money to that use shall be for a longer term than two years; to pro164 


\section{THE TREATY-MAKING POWER}

vide and maintain a navy; to make rules for the government and regulation of the land and naval forces; to provide for calling for the militia to execute the laws of the Union, suppress insurrections, and repel invasions." Further, "all bills for the raising of revenue shall originate in the House of Representatives; but the Senate may propose or concur with amendments as on other bills."

Practically here is a formidable restraint upon the effect of the treaty-making power. The authority of Congress in all these matters cannot be denied, limited, or transferred to others by the President and Senate of the United States. If any exercise of these powers is necessary to execute the obligations of a treaty, it depends on the will of Congress whether or not they will be exercised.

It is undoubtedly within the jurisdiction of Congress itself to determine the question of its duties and its powers in this respect. There is in the Constitution no provision for either executive or judicial determination in this regard. If, therefore, Congress-a body 


\section{PROBLEMS IN FOREIGN POLICY}

subject to frequent change-considers that a treaty which it is asked to execute by supplementary legislation, such as a declaration of war, the raising of an army, or an appropriation of money to be used for the maintenance of an expeditionary force, exceeds the limits of engagement authorized by the Constitution, there is no power in the remainder of the Government to compel its action.

No treaty relation, therefore, should ever be entered into which Congress would have good cause for declining to support.

For the foregoing reasons, while it is conceded that the treaty-making power is not specifically limited, from the beginning of our Government it has always been held that it is not unlimited.

When the adoption of the Constitution was under discussion, in answer to a question regarding the extent of the power to make treaties, Madison said:

"In the existing confederacy, Congress is authorized indefinitely to make treaties. Does it follow because the power is given to Congress that it is absolute and unlimited? 166 


\section{THE TREATY-MAKING POWER}

. . I do not believe that power is given to the President and Senate to dismember the empire or to alienate any great essential right. I do not think the whole legislative authority have this power. The exercise of the power must be consistent with the object of the delegation."

At a later period, John C. Calhoun declared: "Although the treaty-making power is exclusively vested, and without enumeration or specification, in the Government of the United States, it is nevertheless subject to several important limitations. It is, in the first place, strictly limited to questions inter alios; that is, to questions between us and foreign powers which require negotiation to adjust them. All such clearly appertain to it. But to extend it beyond these, be the pretext what it may, would be to extend it beyond the allotted sphere, and thus a palpable violation of the Constitution. . . . It can enter into no stipulation calculated to change the character of the Government; or to do that which can only be done by the Constitution-making power; or which is incon167 


\section{PROBLEMS IN FOREIGN POLICY}

sistent with the nature and structure of the Government, or the objects for which it was formed."

"Let it be supposed," said the elder St. George Tucker, in his edition of Blackstone, "that the President and Senate should stipulate by treaty with any foreign nation, that in case of war between that nation and any other, the United States should immediately declare war against that nation. Can it be supposed that such a treaty would be so far the law of the land, as to take from the House of Representatives their constitutional right to deliberate on the expediency or inexpediency of such a declaration of war, and to determine and act thereon, according to their own judgment?" And as John Randolph Tucker said, in 1882: "The question is not whether Congress can annul a valid treaty, but is a treaty valid and binding on the United States which divests Congress of its constitutional functions without its sanction and consent?"

Very few treaties, and none relating to war, can operate proprio vigore. "Suppose," 


\section{THE TREATY-MAKING POWER}

Tucker continues, "a treaty with Great Britain should provide that the Government of the United States should never raise armies, or provide a navy" - or, it might be added, should raise armies or provide a navy of only a given size-“can it be held that the President and Senate may by treaty thus divest Congress of its constitutional duty to do these things? If so, then the treaty-making power may amend, alter, and destroy the Constitution, and hold us bound to submit to this claim of a foreign power conferred and sanctioned by treaty. This cannot be true. It is absurd. These express powers to Congress are limitations on the general power to make treaties." And this learned jurist concludes: "From this review I feel justified in holding that if any treaty seeks to bind the United States to a foreign country in respect of the functional powers of Congress, we are not open to a charge of bad faith if Congress refuses to sanction' a divestiture of its constitutional authority to deal with any subject entrusted to it by specifi169 


\section{PROBLEMS IN FOREIGN POLICY}

cally granted powers in the Constitution of the United States."

We must not permit ourselves to overlook the fact that ours is a popular government, in which the will of the people is a constant factor in shaping public policy. This will is revised at short intervals in the choice of the House of Representatives, elected every two years. It is expressly prescribed in the Constitution that "no appropriation of money for military purposes shall be for a period longer than two years." This limitation profoundly affects the probability of the execution of any military obligations with other nations in the form of treaties; for, if it should be the popular will not to enforce the conscription of armies for the purpose of interfering in matters which the people considered did not concern them, it is almost certain that Congress would not regard itself bound by any treaty, especially one of long standing, to supply the means for carrying it into effect against the popular conviction regarding the national duty.

There is force, no doubt, in the contention 170 


\section{THE TREATY-MAKING POWER}

that the Congress of the United States is under a moral obligation to maintain the honor of the nation, which implies the strict fulfilment of all pledges made by the treatymaking power; but there is even more weight in the affirmation that the treaty-making power is under a moral obligation not to pledge the honor of the nation in doubtful conditions, as well as under a legal obligation not to destroy the freedom of a coördinate branch of the Government by pledging it to a performance beyond the intentions of the Constitution, from which all its authority is derived. A treaty that should do that would, without doubt, be ultra vires; and, therefore, from the point of view of the Congress, null and void from the beginning.

In the period of our national development when there was still divergence of opinion regarding the relation of the Federal Government to the States, two schools arose as to the nature and extent of the powers delegated by the Constitution. The devotees of State Rights were disposed to seek limitations upon all the Federal powers. The ad- 


\section{PROBLEMS IN FOREIGN POLICY}

vocates of strong central authority, on the contrary, laid emphasis on the necessity of an unlimited authority at least in the treatymaking power, resulting from the sovereignty of the nation, as contrasted with the powers of the States. That debate is now closed. 'The question that is at present pressed upon our attention is of a character wholly new, and not considered in the learned works of our great standard authorities on the treatymaking power, such as Butler, Crandall and Devlin. A new situation has been thrust upon us by the proposal to create a League of Nations, involving responsibilities never before imagined to be possible.

The position reached before this new proposal is well summed up by Devlin when he says: "The treaty power is in a measure incidental to the war power, and under the necessity for national preservation, or even for national benefit, many things can be done that are not explicitly enumerated in the Constitution." This is true, and it has been well not to lose sight of the fact that the United States is a sovereign nation, and may 


\section{THE TREATY-MAKING POWER}

under its sovereign power do what is really necessary for the national interests. And yet, as this writer continues, "It cannot be said that the treaty-making power is unlimited. What the limits are, no one can correctly state, and it is possible that no treaty will ever be made in which the power to make the treaty will be seriously questioned. But.if there ever appears a clear case in which a treaty conflicts with the Constitution, then either the Constitution or the treaty must govern, and there can be little doubt that in such a case the treaty would yield to the Constitution."

The immediate question is, Has such a case now arisen? If a super-government is about to be created, to which the United States is asked to make itself subject, then such a case has arisen; and it is clear that the Constitution forbids the President and the Senate to make a treaty involving such subjection. They do not possess the legal power to enter into such an engagement. If, on the other hand, the Constitution of a League of Nations is nothing more than an under- 


\section{PROBLEMS IN FOREIGN POLICY}

standing between the signatories to act together in their own way, and according to their own will, to accomplish certain common objects, and the Government of the United States is not in any way subordinated to a super-government, there may be a perfect right to conclude such a treaty.

There remains, however, another question. The Constitution of a League of Nations may be so construed as to leave the Government of the United States free to act or not to act upon the recommendations of the Council, and even to prevent by the opposition of the representative of a single Power making any recommendations or decisions of any kind. In that case it seems futile to pretend that it is in any substantial sense a "League," or even an efficient "Entente." But, unless it is further modified, it does create an imperium in which all the signatories have a part; for it proposes to coerce sovereign States which are not members of the League, to abolish existing laws of neutrality, and absolutely to govern through its mandataries, under its own "Acts and Char- 


\section{THE TREATY-MAKING POWER}

ters," dependent peoples placed under its sovereign authority.

Should the United States become a signatory of such a treaty, even though it refused to become subordinate to this new government by service as a mandatary, it would still constitute a part of this new imperium. Its representative in the Council of the League would exercise one-eighth of the sovereign power which that corporation will possess, and he would exercise it without the authority or the restraint of the Constitution of the United States.

In 1803, President Jefferson doubted the constitutional authorization of the American Government to acquire by treaty and to govern the Louisiana Purchase. That point has long since been settled. But one does not find a ready answer to the question, How can the United States, in the person of a representative appointed by the President, even if confirmed by the Senate, participate in issuing "Acts and Charters" for the government of territory not owned by the United States, and not subject either to the Consti- 


\section{PROBLEMS IN FOREIGN POLICY}

tution of the United States or to the laws of Congress?

The disgraceful triple protectorate of the Samoan Islands by the United States, Great Britain, and Germany has been referred to as furnishing a precedent for the scheme of mandatory government. The reference is unfortunate, both with respect to its results, which were shameful, and its nature, which was a threefold promise to protect the neutrality and autonomy of the native government under a puppet king. It was not a contract to govern the islands jointly, but an arrangement to prevent either of the three Powers from governing at all.

Aside from the difficulties which the United States would have either in accepting the responsibility of a mandatary or in controlling mandatory Powers, it is important to comprehend the conception which lies back of this new corporate imperialism.

This is most clearly obtained from the original plan for a League of Nations designed by General Smuts on which the system of mandataries is founded. 


\section{THE TREATY-MAKING POWER}

"So far as the peoples and territories formerly belonging to Russia, Austria-Hungary and Turkey are concerned," he says, "the League of Nations should be considered as the reversionary in the most general sense and as clothed with the right of ultimate disposal." How, one may ask, did the United States ever become a participant in this alleged reversionary right in the remains of these extinct empires?

"Any authority, control, or administration which may be necessary in respect of these territories and peoples, other than their own self-determined autonomy, shall be the exclusive function of and shall be vested in the League of Nations and exercised by or on behalf of it." Where has the United States acquired a share in this exclusive function?

"The degree of authority, control, or administration exercised by the mandatory State shall 'in each case be laid down by the League in a special Act or Charter, which shall reserve to it complete power of ultimate control and supervision." "Whence then proceeds the right to accord this "complete 177 


\section{PROBIEMS IN FOREIGN POLICY}

power of ultimate control" which the United States would share in issuing such mandates?

Plainly, whatever pretences of democracy and self-determination may be put forward in defense of this scheme, it is nothing less than the creation of an imperial syndicate to rule a large portion of Asia and Africa. Two further statements in the Smuts program establish this beyond contradiction. One is that the League is "modeled on the British Empire, including its crown colonies and protectorates." "The two systems," Smuts expressly declares, "would closely resemble each other"; and he adds, "Where the British Empire has been so eminently successful as a political system, the League, working on somewhat similar lines, could not fail to achieve a reasonable measure of success." The other statement is-and this is Smuts' exact expression-“"The League will have a very real rôle to play as the successor to the empires." To this is added that "no new State arising from the old empires shall be recognized or admitted into the League, except as it shall conform to the requirements 


\section{THE TREATY-MAKING POWER}

of the League"; that is, that it shall never, except by permission of the League, become a recognized Sovereign State!

It is for the people of the United States to consider whether such an enterprise as this is one of the purposes for which they entered into the war; and it is certainly a proper question to be answered by the constitutionally authorized treaty-making power, whether or not it is an enterprise to which the United States has the constitutional right to pledge the efforts, the resources, and the lives of future generations of its citizens. 


\section{VI}

THE OBSTRUCTION OF PEACE

The decision of the President of the United States to abandon the long-established traditions of the Republic by absenting himself from the country and, without consultation with the Senate, personally conducting negotiations in a foreign capital, aroused in many American citizens of all political parties a mingled sentiment of astonishment and opposition. The apprehension was inevitable that some very unusual project was in the President's mind; and his silence, even to his official advisers, seemed to confirm this conclusion.

Subsequent developments, particularly the President's speechmaking tour in England and on the Continent, soon made it evident that it was his purpose to carry into effect the establishment of a "general association of nations" suggested in the four180 


\section{THE OBSTRUCTION OF PEACE}

teenth rubric of his peace terms of January, 1918; and that he was relying upon popular confidence in his personal leadership to cause the European governments to conform to his views.

Although many Americans thought that the first necessity was the prompt conclusion of a peace of victory with Germany, and were fearful that the discussion of theoretical questions would postpone it, they awaited in silence the disclosure of the President's intentions.

When, on February fifteenth, they were able to form at least a preliminary judgment regarding the "Constitution of the League of Nations" which was then published, it was by no means unanimous. The document in question was variously understood and was in evident need of authoritative interpretation. $^{1}$

It was with surprise and regret, therefore, that the country received the announcement, on the occasion of the President's brief visit

${ }^{1}$ See the Covenant as originally agreed upon at Paris at the end of this volume. 


\section{PROBLEMS IN FOREIGN POLICY}

to the United States, in his speech at Boston, that he resented any dissent from his decisions and any criticism of the document prepared at Paris. As very little criticism had at that time been expressed, since the country was awaiting further enlightenment, the public was amazed at the President's expressed desire for a "challenge," which he declared he would consider as an "indulgence," accompanied with a reference to his "fighting blood" and a wish for an opportunity to "let it have scope."

In view of the fact that the people were expecting from the President a clear and dispassionate exposition of the purport of the project of a League of Nations and its relation to the interests of the United States, and were waiting to receive from him with respectful attention a message which would aid them in forming a judgment of its merits, they were unable to understand the belligerent mood with which the duty of immediate and unqualified acceptance of the project was urged; and this unexpected display of personal resentment of any independent 


\section{THE OBSTRUCTION OF PEACE}

judgment on the part of the public desiring enlightenment on a subject of such great consequence, and even on the part of the Senate of the United States, was regarded as a rather grotesque method of approaching the discussion of universal peace.

That some new international undertaking should result from the experience of the Great War was evident to all thoughtful men, but the problem of the nature and extent of new and perpetual obligations to be assumed by the United States regarding other countries, is too serious to be treated in a light manner, and the solution of it too heavily charged with consequences to be accepted without careful consideration by all whom the consequences will affect.

The circumstances in which this country has been placed by the President's decision to carry into execution a policy in contradiction to all the traditions of the Republic find no parallel in the history of any free people in the enjoyment of constitutional liberty. They recall the occasion when the former German Emperor, without consult183 


\section{PROBLEMS IN FOREIGN POLICY}

ing the constitutionally authorized officers of the German Empire, undertook, in his private capacity, to carry on negotiations with a foreign power by procuring an alliance with the Czar of Russia; and the other occasion when the same sovereign attempted to influence the sentiments of the British people by an expression of his personal views in a published interview, and was called to account by the Reichstag. In these instances of purely personal diplomacy, which have been severely criticized both in Germany and elsewhere, the sovereign merely assumed that he had a perfect right to propose and carry into effect what he believed would be for the good of his country. The ground of objection to his conduct was not that as sovereign he did not have charge of the foreign relations of the Empire,-a duty which the Imperial Constitution imposed upon him,-but that he had exceeded the constitutional limits in his method of procedure; in brief, that his authority was not personal but official, and that officially he could speak and act only in conjunction with 184 


\section{THE OBSTRUCTION OF PEACE}

other officers also speaking and acting in their joint capacity.

It is, of course, not disputed that the President of the United States is charged by the Constitution with the duty, "by and with the advice and consent of the Senate," of negotiating treaties with foreign governments. It has, however, been customary, and it is the evident intent of the Constitution of the United States, that in the process of treaty-making, even in the most ordinary matters,-much more in the case of the settlement of the most important issue regarding the peace and safety of the world that has arisen in the present generation, or is likely to arise,-the President should not proceed alone. As Hamilton wrote in the "Federalist," when urging the adoption of the Constitution, "The history of human conduct does not warrant that exalted opinion of human virtue which would make it wise in a nation to commit interests of so delicate and momentous a kind, as those which concern its intercourse with the rest of the world, to the sole disposal of a magistrate 185 


\section{PROBLEMS IN FOREIGN POLICY}

created and circumstanced as would be the President of the United States."

If this caution was deemed necessary regarding decisions affecting merely those matters relating in a general way to "intercourse with the rest of the world," what is to be said of a scheme to revolutionize the whole plan of international relationship, involving permanent and unalterable bonds of obligation between many nations as yet unnamed in the Covenant, and thus far nonexistent as established and generally recognized States?

Certainly, it could never have been contemplated by the founders of this Republic that one man, however great, and wise, and noble, should be empowered to pool the interests of this nation with those of other nations unless "by and with the advice and consent" of at least one branch of the representatives of the people, and thus to commit both of the legislative branches of the government and the property and persons of the people to undertakings incapable of previous precise definition and in terms so 186 


\section{THE OBSTRUCTION OF PEACE}

broad that they might easily give rise to controversy and even to ultimate dissent and refusal.

Could it have been imagined that any person honored with the prerogatives and responsibilities of the presidency of the United States would even presume, in defiance of public opinion, to disregard the precedents of more than a century, and insist upon leaving this country repeatedly, and for long periods, in the midst of important public business, and appoint himself, accompanied by a retinue of persons chosen only by himself and wholly subservient to his dictates, as the personal negotiator, not of an immediate peace,-which alone might justify an unusual procedure, in order that the victors in a frightful war might promptly guard themselves against future aggression in the manner desired by those most exposed to danger,-but to impose upon other nations, as the price of future American aid and friendship, a plan of world reconstruction evolyed from his own inner consciousness, which had not only never been publicly dis187 


\section{PROBLEMS IN FOREIGN POLICY}

cussed by his fellow-citizens, but had never been disclosed even to the coördinate branch of the Government in the exercise of the treaty-making power?

Such a course could certainly never be taken "by and with the advice and consent of the Senate." And it should not be overlooked that in the making of treaties it is "advice," as well as consent, which is authorized as essential to the proper performance of that duty.

Who of our American Presidents has ever placed such confidence in himself, or so presumed upon the confidence of others, as to demand the privilege of acting without such advice, or would exercise it without diffidence and every fortification of wise counsel, even if urged by his fellow-citizens to assume this responsibility?

In Europe, where the head of a State has great authority, no sovereign would undertake so large an enterprise. Once, by accident, the late King of England, Edward VII, whose discretion was unusual, met and held conversation with another sovereign, 188 


\section{THE OBSTRUCTION OF PEACE}

without the presence of a minister. There were no negotiations, and probably there was no utterance on either side beyond what the courtesies of casual intercourse demanded; but immediately there was public criticism in the London newspapers of this disregard of the British Constitution, and it was demanded as a matter of public right that the sovereign should not hold such conversation without the presence of a minister. There was probably only one sovereign in Europe who would resent such criticism, and he is no longer a sovereign.

An American president, it may be thought, is himself his own prime minister. This is an error. He is a definitely delegated representative of a sovereign people, possessing no powers which are not included in the constitutional designation of his functions, by which also they are strictly limited. By etiquette he ranks with royalty in a foreign country because he is the head of a State; but in point of influence he is for that reason more potent than any minister. An American president is never embarrassed by 


\section{PROBLEMS IN FOREIGN POLICY}

the presence of his ministers. A prime minister is the creature of a Parliament, and subject to its will. He can be overthrown at any moment, and a successor takes his place. A president can be impeached-a difficult process-but he is as secure in the exercise of power, within constitutional limits, during his term of office, as a treasure is secure in a steel safe-deposit vault behind the trusty bolts that will be withdrawn only when the time-lock releases them.

From a European point of view, the President must be taken at his own selfvaluation. It is naturally assumed that what he promises he can perform. When, therefore, he states what the United States will do no one questions his powers of execution. He carries the destiny of the country in his closed hand more effectively than any king or emperor under a parliamentary régime could do.

While an American president has this advantage over any minister or even any sovereign in Europe, the President of the United States well understands the embar- 


\section{THE OBSTRUCTION OF PEACE}

rassment of the heads of other governments at a moment when combined strength is needed to facilitate an issue from a condition of emergency. Without America the balance of power that has won the war would be lost and the victory forfeited.

In such circumstances the President does not hesitate to speak disparagingly of European governments. Unless they adopt a "League of Nations," he declares openly, they are likely to be brushed aside. The "people," he affirms, are the ultimate authority, and it is to the people that he appeals. It is upon this popular pressure that he depends to influence the governments, of whose spontaneous inclination he expresses doubts. "The nations of the world," he said in his speech on landing at Boston, "have set their" heads to do a great thing, and they are not going to slacken their purpose." But he hastens to explain that he does not mean the governments. Having received the plaudits of the multitude as a distinguished foreigner and apostle of liberty, when he made his tour of Europe before the Peace Congress as191 


\section{PROBLEMS IN FOREIGN POLICY}

sembled, he has made evident to his own mind something which the governments seem not to have been aware of before, but with which he affirms they are duly impressed now. "When I speak of the nations of the world," he says, "I do not speak of the governments of the world. I speak of the peoples who constitute the nations of the world. They are in the saddle and they are going to see to it that if their present governments do not do their will some other governments shall. And the secret is out and the present governments know it."

What is the nature of this "secret"? With whom has our President been conferring? The governments now also are said to participate in this disclosure, but apparently it did not come originally from them. It is something that has been forced upon them through popular pressure, and it is upon this that the President counts as the basis of the "League of Nations" which the governments will be compelled to accept or give way to others. His confidence is not founded upon those with whom he has been negotiating, but 


\section{THE OBSTRUCTION OF PEACE}

upon those who will have "other governments" decide the question if their will is not obeyed.

Who are those "other governments"? Are they governments foreign to these peopleours for example - who are to force obedience to the popular will, or are they revolutionary governments yet to be created? Would the President of the United States be pleased to have any foreign potentate, or even an ambassador, tour the United States, making popular speeches in our cities, and then make such observations regarding the American Government with which the stranger had come to negotiate?

Judging by the President's estimate of the European nations - and he is speaking not of governments but of nations now, by which he says he means "peoples"-Europe is sadly in need of a guardian, but would prove an unruly ward.

Here is his graphic picture of the nations with which, in the future, he desires us to be closely associated, and by whose collective 


\section{PROBLEMS IN FOREIGN POLICY}

judgment he wishes our future policy to be determined:

"You understand that the nations of Europe have again and again clashed with one another in competitive interest. It is impossible for men to forget these sharp issues that were drawn between them in times past. It is impossible for men to believe that all ambitions have all of a sudden been foregone. They remember territory that was coveted; they remember rights that it was attempted to extort; they remember political ambitions which it was attempted to realizeand, while they believe that men have come into a different temper, they cannot forget these things, and so they do not resort to one another for a dispassionate view of the matters in controversy."

If this is a just estimate of the European nations, it would appear to be the part of wisdom for a distant people to keep as far as possible from intervention in any of their quarrels. The picture, however, is drawn with no discrimination, and is as erroneous in substance as it is unjust in its implications. 


\section{THE OBSTRUCTION OF PEACE}

It is monstrous to include innocent Belgium, which did resort to the good faith of others for a dispassionate view; or France, which has been made the victim of every crime; or Great Britain, which has played a noble part in the endeavor to avoid strife and to save the world from the ruin of civilization, in the picture of a discordant and distrustful Europe which the President has drawn in the paragraph just quoted. These countries have stood together, and fought together, amidst great sacrifices, to put down aggression; and this is the first time that any one has revived the unhappy memories of a past that has been buried, to question the solidarity and mutual confidence that existed in the Entente before the President went to Europe. It is injurious and unpardonable to try to make it appear that America, and America alone, can harmonize a discordant Europe, and lead the music in a new concert of world power. The nations of the Entente and the governments of the Entente are as capable of pursuing high ideals and creating the conditions of peace as America herself, 


\section{PROBLEMS IN FOREIGN POLICY}

and are as much disposed to do so. It is both sophistical and reprehensible to appeal to American pride, and to exalt American conceit, by detraction from the capacities of Powers with problems far more serious to solve than any which confront this nation.

The truth is that America very tardily, but with abundant and long disregarded warning of what awaited her, finally came into the war in time to prevent the defeat of the Entente by adding a fresh force to tip the scale of the balance of power, and it was the new equilibrium that won the war.

It will require the maintenance of that superior counterpoise to conclude and enforce a victorious peace. That is the immediate problem, and the only immediate problem. The imposing of just, but necessarily punitive, terms of peace on Germany and her allies would secure the peace of the world for a long time to come. Ulterior questions of international reorganization could then be discussed calmly and effectively in the light of the conditions which would prevail when peace had been concluded and the 196 


\section{THE OBSTRUCTION OF PEACE}

power to enforce it has been demonstrated. Until that power can be proved to exist by actual achievement, the speculations about permanent and universal peace are mere excursions in dreamland.

Instead of promoting peace, the efforts of the President of the United States to impose his own views and to array the populations of other countries behind them by bringing pressure-if that has actually been the case - upon other governments have seriously impeded and obstructed the only peace in which the world is really interested at this time, and for the need of which whole nations are dying with hunger and are kept in an abnormal and dangerous state of mind as a climax to their physical distress. In the meantime the Entente is weakening through discouragement and the enemy is reorganizing, if not for resistance at least to display a refractory attitude toward conditions of peace that could at one time have been easily imposed.

There is no division of opinion in the United States regarding the duty of this 197 


\section{PROBLEMS IN FOREIGN POLICY}

country to stand firmly with our allies in this war in the complete suppression of a common enemy and the maintenance of a peace thus imposed. Yet the President raises the sophistical question, "If America were at this juncture to fail the world, what would become of it? I do not mean any disrespect to any other great people when I say that America is the hope of the world, and if she does not justify that hope the results are unthinkable. Men will be thrown back upon the bitterness of disappointment not only, but the bitterness of despair. All nations will be set up as hostile camps again; the men at the peace conference will go home with their heads upon their breasts, knowing that they have failed-for. they were bidden not to come home from there until they did something more than sign a treaty of peace."

What necessity is there for raising the impertinent and defamatory question, What would become of the world if America failed to do her duty? The American people have no thought of failing in the performance of their duty, and the description of what would 


\section{THE OBSTRUCTION OF PEACE}

happen if they did fail is superfluous. The real question is, What is America's duty? and it is not answered by a dogmatic assertion that America must make herself responsible for the future peace of the whole world, which may be beyond her powers of accomplishment. Her plain duty is to do now what she can do, which is by loyal coöperation with her allies to impose and maintain immediate peace on a common enemy growing every day more dangerous.

The President has never frankly spoken of the Powers with whom we have together fought in this war as our "allies." For a long time he was in a state of cold neutrality regarding them. Gradually they became in his mind "associates," but they have never seemed nearer than that; and to-day his aim is to place them, after this intimate companionship in action and suffering, in which our soldiers and sailors have fought side by side with British, and French, and Belgian, and Italian combatants to win a common cause, in a "general association of nations" to which 


\section{PROBLEMS IN FOREIGN POLICY}

he would have all peoples irrespective of their affinities equally belong.

The President's mind seems always to dwell in a region of abstractions. The concrete does not appeal to him. Overlooking the pressing necessity of immediate peace, the one imperative duty in this regard has not been performed. His policy has been, and is, world reconstruction first and peace afterward. This policy has obstructed and prevented the action by the Entente Allies that should have been taken, and would have been taken, but for his personal interference. It was the right of the Entente Allies, as victors, to impose an immediate peace upon the enemy; and it was the duty of the United States not only to aid in this, but to secure the execution and preservation of the peace after the treaty of peace was signed. It could not then be said of it, as the President says, that such a treaty would be a "scrap of paper."

If, in November, 1918, when the German armies were defeated in the field and called for an armistice, a peace had been signed 200 


\section{THE OBSTRUCTION OF PEACE}

during that month at Berlin, Germany and her allies would have known that they were beaten, and that the terms insuring a European peace would be imposed and would have to be carried out. Among those terms it would have been proper to include this: that any attempt on the part of the Central Powers or their allies to make an unprovoked attack upon any of the Entente Powers would be regarded as an attack upon all, including the United States. That would have been the honorable way for America to have treated her co-belligerents in the war against a common enemy, and that alone would have been sufficient to dispel all thoughts of war for a long time to come. Peace once secured, the new nationalities would have had an opportunity to complete their organization under conditions of peace, and Russian Bolshevism could have been taken in hand and suppressed by a united Europe. France would have been made at once secure. Without this, the war has been virtually lost. That security was the first and most pressing problem, and it is still unsolved.

201 


\section{PROBLEMS IN FOREIGN POLICY}

And what is the situation that has been allowed to develop? I quote the words of one of the most candid and best informed observers of the proceedings of the Peace Conference now in Paris. "Mr. Wilson came to Paris," says Mr. Frank H. Simonds, "resolved that there should be a league of nations. . . Finding French interest and French attention fixed upon the salvation of France rather than upon the formulation of the principles of a league of nations, Mr. Wilson and those associated with him were not successful in concealing their disappointment or their disapproval of what seemed to them a particularistic national policy. When France as a whole asked Mr. Wilson to go and see her devastated regions, that he might understand her heart, he returned a cold and unequivocal negative. I do not think that any single act of any man ever carried with it profounder disappointment than Mr. Wilson's refusal to go to the northern regions and see what the boche had done.

"And we have had week after week, a 202 


\section{THE OBSTRUCTION OF PEACE}

slow but sure change in French emotion with respect to the President. He was hailed by the little people of France as a savior. He was hailed as a man who came from another world to deliver France and other peoples of the world from the shadow of tragedy which had been, and little by little his course here had the effect at least of creating the impression that he cared nothing for the life or death of France, that he was not concerned with those things which the tragic years of war had burned into the soul of every French man and woman.

"I do not think it possible accurately to represent how profound was the disappointment of France at this course of the American President. A sense first of desertion and then of utter isolation crept into the French heart, as more and more the American attitude toward France passed from mere coldness with respect of French necessities to open criticism and hardly concealed suspicion. I do not think one would exaggerate by saying that three months ago France believed the war won and to-day, as 203 


\section{PROBLEMS IN FOREIGN POLICY}

a result of what has occurred here in the peace conference, there is something amounting to real terror lest the war shall be lost after all, and France left alone again across the pathway of a Germany increased in power and population by the last war."

These words were received from Paris on the very day when the President was delivering his speech in Boston, in which there was not one word regarding the sufferings and peril of France, but the intimation of changes of government in Europe, if a "League" was not accepted. At the same time the newspapers were informing us that the Constitution finally assented to as a project for a "League" is by no means a spontaneous embodiment of the desires of the fourteen nations alleged to have adopted it. We were assured that the "League" had been "on the rocks," because Monsieur Clemenceau had urged that France could not subscribe to a compact that did not offer her security; whereupon the situation for the "League" was saved by an American diplomat's sending for Monsieur Bourgeois and 204 


\section{THE OBSTRUCTION OF PEACE}

saying to him "that President Wilson was very near the limit of his patience in the matter," was very much chagrined by the attitude of the French press, which was pleading for the security of France, and would perhaps drop the whole question of a "League of Nations." It was then put squarely to Monsieur Bourgeois that he would have to decide between this compact and no "League" at all. After consulting Monsieur Clemenceau, Monsieur Bourgeois reported his reluctant acceptance of the proposed covenant rather than permit France to be thus deprived of the goodwill of America.

It is known that when the President went to Europe the main object of his going was that he might be able to say privately what he did not wish to write or to discuss openly. He had in mind a program of universal peace which he had gradually thought out in isolation without giving it full publicity, based on the conception of a "League of Nations," a project which had been strongly advocated for some years by the "League to Enforce 205 


\section{PROBLEMS IN FOREIGN POLICY}

Peace." Such a "League," as foreshadowed by the President in his public speeches, involved a "general association of nations" thatwould mutually guarantee the independence and the territorial integrity of all its members; that would secure freedom of navigation upon the seas, alike in peace and war; and that, by the removal of economic barriers, would establish equality of trade conditions for all nations.

At the time this idea of a "League" was conceived, it was intended as a medium for reconciling the differences made prominent in the Great War by securing a compromise peace which might afterward be made the basis of a permanent peace. This was the inner meaning of the "fourteen points." These rubrics were formulated at a time when victory on either side was thought by the President to be still doubtful, and when his original idea of "a peace without victory" may have seemed to him the best method of demonstrating the utter futility of war.

The problem at that time seemed to him to be, to formulate a plan that could be ac206 


\section{THE OBSTRUCTION OF PEACE}

cepted by both sides by promising to secure in the future the most important interests of all the belligerents. The wrong done to France by Prussia in 1871 was to be "righted in order that peace might once more be made secure in the interest of all." Belgium was to be "evacuated and restored" as a sovereign State, without any stipulation of indemnity. In return, since the new "association" was to be "general," Grermany was to have a place in it, and also to enjoy the status quo determined by the peace after surrendering the conquered territories, together with all the advantages which the plan implied. Great Britain was to abandon her naval supremacy under the protection of the "League." Armaments were to be reduced to the lowest point consistent with domestic safety. A free, open-minded, and absolutely impartial judgment of all colonial claims was to be assured, based upon a strict observance of the principle that in determining all such questions of sovereignty the interests of the populations concerned must have equal 


\section{PROBLEMS IN FOREIGN POLIC̨Y}

weight with the claims of the government whose title is to be determined.

Thus, it was imagined, the gates of the temple of Janus would be permanently closed. There would never be any more war, because there would remain no just causes for war. As to the unjust ambitions of nations, these would of course wholly disappear!

As a plan for universal and permanent peace, this is comparable with the great proposal attributed by Sully to Henry IV of France, and should no doubt appeal to the imagination and the sympathies of peaceloving men in a similar manner; but, like that and other great and noble conceptions of world reorganization, its defect was that it did not reckon with the fact that no Great Power was ready to accept it in its entirety except as the result of military defeat.

The truth of this last statement is demonstrated by the events which have followed. When the fourteen rubrics of peace were proposed, in January, 1918, seeing that they embodied a purely mediatory proposal, Ger208 


\section{THE OBSTRUCTION OF PEACE}

many was ready to accept five of the fourteen points, but these were the five that the Entente Allies were not willing to accept because they implied that Germany was to be treated and trusted as if she were a just and pacific nation. In October, 1918, when the certainty of her defeat dawned upon her, and her allies were failing her, Germany, in the belief that all fourteen were intended in a mediatorial sense, was ready to accept them all "as a basis for discussion." The Entente Allies when invited, not wishing to alienate the President, whose support was necessary in the war, also accepted them with one exception, in the belief that the conditions of the armistice would be sufficiently strong to show that a victory had been won, and on that basis peace was possible with honor.

When the President went to Europe, he hoped to persuade the Entente Allies to accept his entire plan. He intended to convince the British Government that it would be in the interest of Great Britain to accept his idea of the "freedom of the seas" under international control, for if this were not 209 


\section{PROBLEMS IN FOREIGN POLICY}

accepted, the United States would in future prepare to hold the supremacy of the seas; and, to impress this point, he directed the Secretary of the Navy to propose immediately an extensive programme of naval construction, and through him exhorted Congress to hasten in passing the necessary legislation, subject to its non-execution if the "League" were formed.

If the British Government had resented this proposal, the consequences to the Entente would have been serious, indeed, but, retorting that, as the two nations were fast and inseparable friends, the building of a greater navy by the United States would afford to Great Britain a new sense of security, the agile-minded Premier convinced the President that British sea-power could not be a menace to neutral nations, since, under the "League" there would be no neutrals in any war in which Great Britain could engage; and the President is reported to have declared that "the joke was on him for not thinking of this," and the "freedom of the seas" is thus settled! 


\section{THE OBSTRUCTION OF PEACE}

With regard to the "general association" promised in the fourteenth point of the President's peace programme, a similar renunciation has been made, as it was certain from the beginning it would have to be. Nothing could induce France, after what she has endured, to enter any "general association" of which Germany is a member; and of course Russia,-although arrangements were made to negotiate with the Bolsheviki, in spite of Monsieur Clemenceau's declaration that France would never associate with assassins, - could not be included. Germany's recent allies will also, no doubt, if the "League" comes into being, and probably some other Powers, have to sit a long time in the anteroom, even if they are on the waiting list. As a scheme of world organization, therefore, the President's plan is far from being accepted, although so recently as his speech in Manchester on December 30th, he voiced his conception of what the "League" should be in the words: "If the future had nothing for us but a new attempt to keep the world at a right poise by a balance of power, the 211 


\section{PROBLEMS IN FOREIGN POLICY}

United States would take no interest, because she will join no combination of Powers which is not a combination of all of us."

It is precisely such a combination as he here repudiates which the President now insists it is our sacred duty to join, or remain "selfish and provincial." It is Monsieur Clemenceau who has had his way regarding the "balance of power"; for the "League," as the President represents, would be "a scrap of paper" if the power of the United States were not thrown into the scale to render preponderant this combination of four Great Powers and some little ones, which latter will need but not afford protection.

From the moment when the President saw the "joke" regarding British naval supremacy, the British Government became as eager for the "League" as the President had been. In this the Government was joined by the British press and British public opinion, for it was seen that the adherence to such a combination, with the United States as a member, would create a preponderant balance of power. With an American alli212 


\section{THE OBSTRUCTION OF PEACE}

ance in which the United States would assume equal responsibility with the European Entente Powers for the peace and control of the rest of Europe, a "League" would undoubtedly be a great security to them all. It would, in effect, place the balance of power entirely in the hands of the "League."

It is not surprising, therefore, that Great Britain, with vast imperial interests in every part of the world exposed to attack, should become an eager advocate of the proposed combination. Retaining her naval supremacy, acquiring no new obligations, and relieved of a share of her responsibility, Great Britain is much interested in bringing the "League" into being. General Smuts, a former Boer officer who had become an ardent imperialist, in order to satisfy the President's desire for a "League" of some kind, had made ready for use in the Peace Conference a detailed plan that would be acceptable to Great Britain. That plan, which contained a provision for the administration of the colonies conquered from Germany, now figures more largely in the proposed "Con213 


\section{PROBLEMS IN FOREIGN POLICY}

stitution of a League of Nations" than any other. The idea of administration by "Mandataries" ingeniously extricates those who have taken the German colonies from the dilemma of either stultifying their claims to democracy by annexing them outright or returning them to Germany, by placing them under the administration-temporary, no doubt-of other Powers, preferably of the United States, which would thus be drawn into the complications of a joint imperialism in distant parts of the world.

It is quite intelligible that, although it was assumed in Europe that the President speaks with authority for the purpose and policy of the United States, there is in this country no corresponding unanimity regarding the obligations which the United States should undertake to assume in remote and turbulent parts of Europe, Asia, and Africa, or the islands of the Pacific.

In the United States it is clearly perceived that we should be an unequal partner in the combination that is proposed; and the President not only admits this, but urges it as a 


\section{THE OBSTRUCTION OF PEACE}

reason for our accepting new and unpredictable responsibilities.

In stating the case thus candidly, there is no intention to disregard the strong friendship which has grown up with Great Britain during the latter years of the war. On the contrary, it is timely to emphasize the wish that this friendship may always continue to be close, loyal, and permanent; but it is the part of wisdom to avoid those complications which, in circumstances that may arise, might tend to alienate two great nations by too close an intimacy in affairs that separately concern them. Great Britain and America have many great interests, as well as many strong bonds of sympathy and understanding, in common. We have among the nations no better friend, unless it is France, for which we have a particular affection of long date and recent demonstration. The British fleet, it is true, annoyed our shipping and embarrassed our trade early in the war, but before the war was ended it became our faithful protector and co-partner. Anywhere in the world, on sea or land, we feel 215 


\section{PROBLEMS IN FOREIGN POLICY}

safe where the British flag floats over us, and we should not wish to see it lowered. But before we could agree that we would send our sons and brothers across the seas to fight to keep it wherever it floats outside Great Britain itself,-which to many of us is a motherland,-we should have to ask ourselves whether we or our fathers would have fought to place it everywhere in the world where the policy of the British Empire has carried it.

Nations and governments, like individuals, from their very nature, must limit their responsibilities. Without this they weaken and destroy their own capacity for usefulness. It is necessary to be strong before we can help the weak, and we render no real service to those for whom we become entirely responsible. It is for this reason that we ought not as a nation to permit ourselves to be influenced by an appeal to our national pride or the personal sentiments which might properly control us in affairs of a private nature.

The personal experience of the President during his unprecedented ovation in Europe, 216 


\section{THE OBSTRUCTION OF PEACE}

as the head of a nation that turned the scale in the war, is of a kind that appeals powerfully to the emotional element in his nature. $\mathrm{He}$ has led the Entente nations to expect great things of America, and he undoubtedly feels responsible for realizing these expectations. He has held up to enraptured audiences that have thronged to see and hear him the vision of a reconstructed world. Naturally they have had faith in him. They were longing for peace, and he has pictured to them Utopia. He returned to America with a demand for the realization of his promises. The urgent appeal to the United States to adhere to a "League" without debate, without hesitation, and without regard to any question of national interest or expediency, is the almost necessary psychological consequence of the President's self-imposed activity. The Covenant presented for adoption is not, it is true, the realization of his original purpose; but it is a result of it,- the nearest approach to it that he could achieve. To reject it utterly would be a repudiation of his leadership. The acceptance of it, at least 217 


\section{PROBLEMS IN FOREIGN POLICY}

in substance, is necessary to his prestige. It is for this that his "fighting blood" is aroused. It is for this that the President's public and his still more fervid and less parliamentary private denunciations of all critics and opponents, have seemed to him justified. The rôle must be carried to its logical conclusion.

In commending immediate action the President employs none of the arguments which would be expected of a statesman. He has found in Europe, he reports, a general confidence in the disinterestedness of America as a country of great ideals. This is the chief impression of his experience. He said to his Boston audience: "Every interest seeks out first of all, when it reaches Paris, the representatives of the United States. Why? Because-and I think I am stating the most wonderful fact in history-because there is no nation in Europe that suspects the motives of the United States."

It is frankly admitted that all other nations have "interests," that they are objects of contention among themselves, and that all these nations turn to the United 218 


\section{THE OBSTRUCTION OF PEACE}

States as a great disinterested benefactor. The United States alone is presumed to have no interests, or to act without regard to them. The President never mentions them. He even scorns a reference to them. His appeal to the country is as emotional as his experience has been. We should, he affirms, act in this great emergency "without regard to the things that may be debated as expedient."

There is grave danger to our national life in resting a decision upon an appeal to the emotions of the people. In the past our statesmen have not hesitated to defend the national interests entrusted to their keeping. These interests are now deliberately excluded from view and sunk in the advocacy of a vague internationalism. 'This is proposed ostensibly in behalf of "peace," but it will have other consequences. The prospect is confessedly one of interminable suspicion, intervention, and restricted independence. In the end, nations will settle their differences in the manner that seems to them at the time in accordance with their highest interest. Nothing can more effectually 219 


\section{PROBLEMS IN FOREIGN POLICY}

breed strife than to mix them up in one another's disputes,-disputes which, if the nations desire mediation, can be more readily composed by a free, strong, united, and independent America, whose word of counsel would be listened to, than by an America bound to the control of a group of Powers, constituting perhaps a third of Europe, in which her voice would be drowned in the general clamor.

We have, of course, a great interest in peace. We have a special and immediate interest in a conclusive and permanent settlement of the actual issues of the war, in which our honor as well as our interests as a nation is bound up. We cannot without disloyalty desert our allies so long as we have a common enemy, but this does not make it necessary to assume new obligations in other parts of the world. Unless we assume these, the President assures us, America "will have to keep her power for those narrow, selfish, provincial purposes which seem so dear to some minds that have no sweep beyond the nearest . horizon." 


\section{THE OBSTRUCTION OF PEACE}

It is difficult to see the reason for this reproach, and it is little short of exasperating to those who saw America's duty and urged the performance of it long before the President's vision had swept beyond the nearest horizon, when he was urging neutrality in the midst of international outrage, not only on the part of the Government, but in the thoughts as well as the deeds of citizens; when he was still asking what the war was about, and declaring that we had nothing to do with its causes or its results; when he was advising a peace without victory; when he was elected to the presidency because he had kept us out of war; when he was still regarding strict accountability as implying nothing more than liability to pay a money indemnity for American lives, destroyed ruthlessly in violation of International Law and every instinct of humanity, and yet did not see that preparation for war alone could rescue the nation from contempt. It is, therefore, impossible not to resent the attempt by mere rhetoric and insinuation to silence the free speech of men who are entitled to be heard 221 


\section{PROBLEMS IN FOREIGN POLICY}

on international and constitutional questions affecting the destiny of the nation and its unveiled future by a public reference to them as "minds that have no sweep beyond the nearest horizon"; even when this is spoken by the President of the United States.

It is not the path of peace that is being pursued, but a course that is obstructive of peace. The Entente that has saved Europe has been strained by the introduction of new and irrelevant issues, many months have been consumed in deliberations and journeys not related to the ending of the war, and the American people are in danger of being seriously divided over a question that can be rightly settled only on the basis of an existing peace, when they may act with freedom and not under compulsion. If the world is to be made safe for free nations, it will be by an Entente of Free Nations. While that lasts there is hope; but if that ceases to exist, hope will have departed. The moment bonds are felt they will destroy the power that has won the war. By whatever name it is called, there is no third condition between super222 


\section{THE OBSTRUCTION OF PEACE}

government and the independence of free peoples. Discussion over speculations about such a possibility are but a waste of time, for the free nations do not desire a supergovernment. There remains, therefore, no possibility but an Entente of Free $\mathrm{Na}$ tions, however it may be named, and our one solicitude should be that it be not destroyed.

To the word "League" there is in itself no objection, except to the bondage which the word implies. For the improvement and enforcement of International Law, for the pacific settlement of disputes, for aid to free nations exposed to danger, for the suppression of Bolshevism, and for international bodies to deal with these subjects, there is great need. But these ends cannot be accomplished by mere paper machinery, which presents only a new cause of disagreement, - a new occasion for difference of opinion and of strife. If the ideals of civilization are not safe in the hands of the free nations, acting freely, they will remain in danger. What 


\section{PROBLEMS IN FOREIGN POLICY}

happens in the future will depend upon what the free nations will to do; and the essential element in their unity, their security, and their effective coöperation is precisely their freedom. 


\section{VII}

THE DÉBÂCLE OF DOGMATISM

Although during four months of secret negotiation American public opinion on the League of Nations remained unsolicited, America has at last spoken. Whatever the outward form of words may be, her voice is clearly against super-national government and for an Entente of Free Nations. The unpledged press and the great hierophants of party opposition have condemned the Constitution of a League of Nations as it was incubated at Paris, and have demanded radical changes as a condition of American support. Every interpretation by its advocates and every amendment proposed by its critics has tended to abolish the "League" and restore the "Entente."1

${ }^{1}$ See the amendments proposed at the end of this volume and compare the original draft with the final draft of the "Covenant."

\section{5}




\section{PROBLEMS IN FOREIGN POLICY}

When it was first published it seemed that the "Constitution" was intended not to solicit the coöperation of the nations to be included under it, but by their agreement to command their future action. Assailed as a super-government, it was pleaded by its defenders that it was not a government at all, but a kind of international social club, whose Executive Council possessed no real authority, and whose sole function was to make "recommendations," which might be accepted or rejected. This defense reduced it to something less than an Entente, because it threw doubt upon its sincerity of purpose.

Instead of treating the "Constitution" as meaningless for a real community of action, the critics sought to endow it with real obligations, by pruning its pretences and making it effective for some at least of its alleged purposes. It remains for the world to judge who were the sincere friends of peace; and especially of a peace to end the war in such a way that the treaty of peace, when secured, would unquestionably be enforced.

Had some open process of this kind been 226 


\section{THE DÉBÂCLE OF DOGMATISM}

adopted in the beginning, it would without doubt have saved much precious time. If it were in the order of the day to continue it deliberately after an actual peace had been declared upon conditions that would render discussion wholly free and entirely amicable, the result would be better still. Nevertheless, the chances for the Entente of Free Nations are to some degree improved even by the tardy and reluctant concession that the document alleged to have been "agreed upon" and to be "unalterable" was not too perfect to be publicly discussed.

It may not perhaps be too late, now that public debate is not openly proscribed as a manifestation of hostility to peace, to consider, at least in an academic manner, some of the provisions which it would still be desirable to eliminate from this document and some of the methods which it would be profitable to abandon.

The Peace Conference at Paris has suffered from too much theory and too little regard to practical results. In the meantime, while the delegates have been preoccu- 


\section{PROBLEMS IN FOREIGN POLICY}

pied with devising defenses against the consequences of a remote future, events have occurred of which they have seemed unconscious, and the irrepressible stream of human activities still flows irresistibly onward. Occurrences have at last reached a point where action must take the place of meditation, or victory will be transformed into defeat.

The theory underlying the Conference has been that all possible future wars must be prevented now; and that, unless this could be done immediately, the present war could not be ended. In other words, the League of Nations, it was held, must of necessity be a part of any treaty of peace.

This theory dates from the attempt to prepare a compromise peace by creating a future situation with which all the belligerents would be satisfied. It rests upon the assumption that while governments are often bad, peoples are always perfectly good; and that, if the governments could be overthrown and the peoples could have their way, there would never be any more war in the world.

As a proposition in political philosophy 228 


\section{THE DÉBÂCLE OF DOGMATISM}

this doctrine has never yet been proved to be true. In the belief of many it is not only incapable of such proof but is erroneous. If it were true, we should be able in a very short time to secure universal peace by a general plebiscite. The truth is that all nations want peace, but they want it in their own way; and, as their own ways differ, they are not likely to consent to perpetual peace until there is created a common interest so great that, to secure it, they are willing to forego all less urgent aspirations. The realization of such a community of interest as this is undoubtedly an ideal to be aimed at; and, in time, it may be possible to attain it. It is, however, an obvious error to insist that such a community of interest must be made universal before an existing common interest in a narrower field can be utilized as a basis for a peace of victory, in which aggression against public right has been overborne and the aggressor is rendered powerless. For unless actual aggression is defeated, is made conscious of its defeat, and is caused to suffer the consequences of it, peace becomes a mock229 


\section{PROBLEMS IN FOREIGN POLICY}

ery. A distinction must be made between a compromise peace, in which the aggressor is treated as an equal, and a peace of victory, in which he must pay the penalty of his offense; or war would become a recognized innocent diversion and peace the mere plaything of participants in a rude and dangerous game of chance. To state the matter concretely, unless the Central Powers and their allies are so weakened and punished for their crimes against the peace of the world that they will not repeat the performance at a more favorable time, the war has been lost to the Entente, and the treaty of peace, no matter what it contains, will prove ineffectual.

The community of interest on which the present peace should be made is the defeat of a common enemy. When that peace is made there will be a long period of comparative repose during which the larger problem of universal and permanent peace might be considered. If, however, the Entente Allies cannot impose a just peace in the concrete, 230 


\section{THE DÉBÂCLE OF DOGMATISM}

what hope is there that they can forever maintain it in the abstract?

The truth is that proposing peace in general has taken the place of imposing peace in the actual particular situation because it was easier to imagine the theoretical potency of a League of Nations than it was to deal with realities. As a result, the common interest which the Entente had when the armistice was signed in rendering Germany powerless for harm in the future, has been held in the background by the discussion of a theory, while the separate interests of the victors in the war have seemed to most of them the only realities with which the Conference would deal or which its conclusions would affect. Thus Great Britain has thought of her maritime supremacy and her colonial conquests, France of her future territorial security, Italy of the control of the Adriatic, Japan of her Eastern interests, Belgium of her rehabilitation, and the new nationalities of their racial integration and safety from their neighbors old and new. The representatives of the United States, 231 


\section{PROBLEMS IN FOREIGN POLICY}

on the other hand, having nothing to ask for except the adoption of their theory of universal peace, have held a position of influence which enabled them to say, "The League of Nations first, and peace with Germany afterward."

The inevitable consequence of such a mise en scène of the Conference was delay, the exaggeration of separate interests, and an effort to make the League serve, as far as possible, these particular national aims, while the original community of interest in the suppression of German aggressiveness was gradually dissipated. In brief, attention to Germany, the new nationalities, the rise and spread of Bolshevism, the growing menace of Russia even in a military sense, was withdrawn, to be fixed on getting into the theory of the League something besides abstractions. This has been in part accomplished. Dogma has answered to dogma, interest to interest, and instead of a pacifically disposed general society of nations agreeing to accept, respect, and maintain International Law as its rule of conduct, we have 232 


\section{THE DËBÂCLE OF DOGMATISM}

an organized balance of power only, dominated by five Great Powers, whose interests have been in some manner incorporated in a Constitution for a League of Nations;all except those of the United States, which seeks nothing but the realization of ideals! If we adopt the theory that a League is a necessary preliminary to a peace with Germany, say the Entente Allies, America must agree to defend us always and everywhere. That is Europe's answer to the President's insistence on a League as a preliminary condition of peace.

The President went to Europe with an ideal. Europe welcomed him and confronted him with the result of its experience. To this experience his ideal has had to adjust itself. The result is not the realization of his expectations. He sought to reconstruct the world. He has been obliged to engage his country in a permanent defensive alliance of a kind that a very short time ago he expressly repudiated, not merely because it is contrary to the traditions of the United States, but as he 233 


\section{PROBLEMS IN FOREIGN POLICY}

emphatically declared because it is incompatible with our national purpose.

Only four years ago he voiced his conviction by saying: "Every man who stands in this presence should examine himself and see whether he has the full conception of what it means that America should live her own life." And, referring to our relations to the rest of the world, he added:

"It was not merely because of passing and transient circumstances that Washington said we must keep free from entangling alliances. It was because he saw that no country had yet set its face in the same direction in which America had set her face. We cannot form alliances with those who are not going our way; and in our might and majesty and in the confidence and definiteness of our own purpose we need not and we should not form alliances with any nation in the world."

At that time the President spoke in words which his countrymen understood. During the Great War he gradually saw that the United States could not remain isolated in 234 


\section{THE DÉBÂCLE OF DOGMATISM}

a world of which it forms a part. We entered the war, as our honor compelled us to do. We became associated with Great Powers in Europe. We had a common cause, and we fought valiantly with them against a common enemy. We won a victory, and what was demanded was a peace of victory. But the President had set his mind on a peace of reconstruction. America's life was no longer to him the highest purpose. $\mathrm{He}$ wanted to be the creator of a new world.

From that moment the President no longer represented America. $\mathrm{He}$ was the victim of his obsession, the reconstructed world. He did not even care for America's consent. He did not seek it. He did not desire it. His mind was closed to it. $\mathrm{He}$ had a doctrine which he apparently felt he could not teach. He made no attempt to teach it. He was resolved to enforce it. Then it would be believed, because it would be no longer merely an idea, it would be a fact.

Such a determination, with all America apparently behind it-although America had 235 


\section{PROBLEMS IN FOREIGN POLICY}

not been asked to speak-could not fail to produce some result; but it was not the result intended. In the contest between the dogma that only a reconstructed world could make peace at all and the pressing necessity that peace should be promptly made, diplomacy wrung from idealism three concessions :

(1) Peace is to be guaranteed to the peacemakers by stereotyping the map of the world as they will make it;

(2) Imperialism may pass for democracy by becoming international; and

(3) Democratic leadership does not require democratic methods of procedure.

The President accepted these results and they were embodied in the "Constitution" sent from Paris and pronounced unalterable. But American public opinion was yet to be learned; and American public opinion, even that most favorable to a League, was not satisfied with the form or the substance of this document.

A new map of Europe is undoubtedly necessary in order to secure the safety of the 236 


\section{THE DÉBÂCLE OF DOGMATISM}

countries inclined toward peace from a new outbreak of aggression; but the Constitution of a League of Nations is not satisfied with this, it demands that the boundaries of the States which are members of the League, together with all their widely scattered colonial possessions, shall for all time be protected by all the associated Powers. This is the first and most conspicuous victory of diplomacy over idealism.

To the uninitiated this Constitution is the Dutgrowth of new and original conceptions, arising out of the peculiar circumstances of recent international experience. It has been heralded as the application of the Christian religion to the problems of international relationship, and glorified as its consummate flower and perfect fruit.

How far this proposed League is from being either new or original will be apparent to those who will compare its provisions with those contained in "The Project of Perpetual Peace," written by the Abbé de St. Pierre, more than two hundred years ago, during the Congress of Utrecht, in 1713. 


\section{PROBLEMS IN FOREIGN POLICY}

The good Abbé's purpose, like the alleged object of the League of Nations, was to make a permanent end of war, and his method was substantially that which is now proposed. His plan was as follows:

1. A contract of perpetual and irrevocable alliance between the principal sovereigns, with a diet composed of plenipotentiaries, in which all differences between the High Contracting Parties are to be settled by arbitration or judicial decision.

2. The number of Powers sending plenipotentiaries to the Congress to be specified, together with others to be invited to sign the treaty.

3. The Confederation thus formed to guarantee to each of its members the sovereignty of the territories it actually possesses.

4. The Congress to define the cases which would place offending States under the ban of Europe.

5. The Powers to agree to arm and take the offensive, in common and at the common expense, against any State thus banned, 238 


\section{THE DÉBÂCLE OF DOGMATISM}

until it shall have submitted to the common will.

6. The plenipotentiaries in the Congress shall have power to make such rules as they shall judge important, with a view to securing for the European Republic and each of its members all possible advantages.

The learned Abbé's plan sought to establish perpetual peace by mutual guarantees of possession. It was rejected as impracticable because it ignored two persistent tendencies of human nature,- the ambition of rulers on the one hand, and national aspirations for freedom and equality on the other. During the two hundred years that have elapsed since his project was published, it has encountered these two obstacles, and not being able to overcome them, could not be realized. There has never been a time during those centuries when the process of political evolution seemed complete. There were always nations that were not yet satisfied. There was always a longing among suppressed peoples for liberation, and among all nations, except the greatest, for an un239 


\section{PROBLEMS IN FOREIGN POLICY}

attained equality. Is it possible to believe that these conditions have changed, or will change when the peace treaty is signed at Versailles? Alongside the "satisfied nations" there will remain the unsatisfied, and the dissatisfied, even among those who are beneficiaries of the peace.

It has been well said that, if the map of Europe could have been thus perpetuated in the time of the benevolent Marcus Aurelius, when it might have seemed desirable, Europe would still be living under the Roman Empire. There would be to-day, if this had happened in the time of St. Pierre, no French Republic, and no free governments in America. The project would have arrested the entire historic development of Europe. There have been moments when to many that would have seemed to be a happy event. What a perfect world this would be to inhabit, if the professions of the Holy Alliance could have been permanently carried into effect, when Their Majesties, the Emperor of Austria, the King of Prussia, and the Emperor of Russia, "having acquired the 240 


\section{THE DÉBÂCLE OF DOGMATISM}

intimate conviction of the necessity of settling the steps to be observed by the Powers, in their reciprocal relations, upon the sublime truths which the Holy Religion of our Saviour teaches," solemnly declared "their fixed resolution, both in the administration of their respective States, and in their political relations with every other government, to take for their sole guide the precepts of that Holy Religion, namely, the precepts of Justice, Christian Charity, and Peace, which, far from being applicable only to private concerns must have an immediate influence upon the counsels of Princes, and guide all their steps, as being the only means of consolidating human institutions and remedying their imperfections."

Could any form of words be more inspiring to the believer, or more appealing to his confidence? The "only means of consolidating human institutions!" and it really seemed to be true. How rude it must have appeared to Their Majesties-and we always have those who assume that they alone know what is good for the world-when Castlereagh, the 


\section{PROBLEMS IN FOREIGN POLICY}

clear-headed realist, the soul of loyalty to the Grand Alliance against Napoleon, the apostle of national freedom, voiced the danger of placing all Europe under the control of this vague idealism which, it was soon discovered, served as a mask of the most pernicious despotism, and imperiled the national liberties of all the remainder of the world.

Thanks to the courage of Castlereagh and his determined opposition to the Holy Alliance, that imperial syndicate was broken up. Had it not been thwarted, and had not the influence inspired by Washington and sustained by Monroe and his advisers warned the King of Spain, supported by this conspiracy, not to attempt to reclaim his colonies in America, they would still, no doubt, be dependencies of the Spanish crown, and more than half of the Western Hemisphere would still be monarchical. But if the project of St. Pierre had gone into effect before the American Revolution, there would have been in 1823 no American Republic to hold aloft the standard of liberty and self-government. There would perhaps be even now 242 


\section{T'HE DÉBÂCLE OF DOGMATISM}

no democratic Britain; for the American Revolution was not merely a war for independence, it was a struggle in behalf of inherent human rights and representative government against reactionary absolutism imported into England, which had nearly undone through parliamentary corruption the whole work of the earlier English Revolution.

It is now proposed to base the League of Nations on the permanence of the map of the world as redrawn at Paris, at least so far as the members of the League are concerned. Its motto is, Beati possidentes. This is the meaning of Article $\mathbf{X}$, which is the one substantial element in the proposed Constitution. This article binds the High Contracting Parties "to respect and preserve as against external aggression the territorial integrity and the political independence of all States members of the League," present and future. It is a solemn and absolutely binding engagement. Had it been in force before the Spanish-American War, Cuba would probably still be a subject colony of 


\section{PROBLEMS IN FOREIGN POLICY}

Spain, a scene of continuous revolution, badly governed, the subject of extortion and oppression, and a nuisance to its neighbors; and there is no provision in the Constitution of the League of Nations that would have furnished a remedy. The sinking of the Maine would not have been held to justify a war against Spain; for it would have been disavowed, and the sovereignty of Spain protected. There are countries that do not govern well; there are countries that will not govern well; and there are countries that cannot govern well; and the only remedy is revolution. Article $\mathbf{X}$ does not, it is true, require aid to a sovereign State in suppressing an unsuccessful revolution; but if any portion of it should attain its independence and the mother country continued at war with it, "external aggression" would be alleged; and the aid of all the High Contracting Parties, economic and even military, could then be invoked against the new claimant of independence.

The perpetual guarantee of territorial integrity, especially when applied to conquered 


\section{THE DÉBÂCLE OF DOGMATISM}

colonies and dependencies, occupied by alien peoples desiring independence, was not one of the objects for which the Entente Allies became associated in the war. It was first suggested in the fourteenth rubric of the compromise peace plan proposed by the President of the United States, who foreshadowed such a "mutual guarantee" as one of the bases of the "general association" in which the Central Powers were intended also to have a place. The League now to be constituted is far from being such a general association. It is, in effect, a new preponderance of power. The reason why it is acceptable to several of the Powers entering into it is that it affords them this guarantee as against all possible enemies in the future. Their interest is in the acquisition of the wealth, the natural resources, and the potential military efficiency of the United States in a defensive alliance. That was not the original purpose of the President; but that is the price he has had to pay for the realization of his idea of a League of Nations, as distinguished from a permanent Entente 245 


\section{PROBLEMS IN FOREIGN POLICY}

with regard to the specific purpose of the war. The European nations would not for a moment have considered the suggestion until the military value of this country had been demonstrated by the part it has taken in the Great War.

Irrespective of any League, the co-belligerents on the side of the Entente Allies are in honor bound to enforce upon the common enemy just terms of peace that will prevent further aggression; but this does not involve the necessity of a permanent engagement to prevent the future dismemberment of surviving empires. It is assumed in this Constitution, and it may be true, that the extensive populations ruled by the countries that now hold them in a relation of dependence are better governed than they would be if they enjoyed self-determination. I have no disposition to raise an issue on this point; but it is not certain that this condition, if it exists, will always remain the same, or that the preservation of territorial integrity, which now covers many conquered peoples, will prove to be the method of justice or 246 


\section{THE DÉBÂCLE OF DOGMATISM}

conducive to peace. There is, however, in this Constitution no provision for the "consent of the governed"; and it is not apparent that there could be without a frank abandonment of imperial claims which the High Contracting Parties have no intention to surrender.

Undeniably, by accepting Article $\mathbf{X}$ the United States would become an underwriter of imperial insurance in which it would not be, and ought not to ask to be, an equal partner. What the United States would gain by this engagement has never been even considered. On the contrary, all questions of "expediency" have been contemptuously waved aside as unworthy of consideration. But it is more than a question of expediency, -it is a question of principle. The ideal of peace is noble, but it is not the only ideal. We are urged as a duty to sacrifice to it not only our interest but our ideal of freedom, the foundation of our conception of selfgovernment. That we should cherish the ideal of peace, and endeavor in the right way to serve it, is a proposition which no true 247 


\section{PROBLEMS IN FOREIGN POLICY}

American will deny; but that we should in any way barter our freedom for it, or abandon our principle of the "consent of the governed," is a quite different proposal. One would be rendering a better service to his country, and in the end to humanity in general, if he should seek to establish peace in some other way. It is not doubtful that the present generation of Americans, and those that are to follow, can be more serviceable to the highest human interests as a strong, free, and independent people than by being bound to do that against which, when called upon to observe the bond, their consciences as lovers of liberty would revolt.

One of the alleged purposes of the war has been "to make the world safe for democracy." This Constitution does not carry out that purpose. It does not in any way refer to it. It is a union and an intended domination of Great Powers, and the small States are treated as of secondary importance. They have had thus far no collective voice. They have been permanently relegated to the rear. Far from being recog248 


\section{THE DÉBÂCLE OF DOGMATISM}

nized as truly "self-determining," the new nationalities are treated as creations, the handiwork of the potters at Paris, who are moulding them out of the débris of the extinct autocracies, Russia, Prussia, Austria, and Turkey, whose populations have been left in turmoil and turbulence by the fall of the only governments they ever knew.

During the protracted negotiations at Paris regarding the League of Nations, a new enemy has arisen, - a form of internationalism more dangerous than any single coalition. It aims at the life of nations and would destroy all national existence. It is, therefore, a time to think first of the national life, to maintain it in its strength, its purity, its freedom, and its established foundations. Nothing but a vigorous nationalism can overcome this insidious enemy, which would divide every house against itself. It is a time, therefore, for every free, self-governing nation to be a master in its own house. Its association with other nations should look toward a peace based on justice with all of them, a willingness to help, but not to be 


\section{PROBLEMS IN FOREIGN POLICY}

bound. It is timely to face this new and all pervading menace of Bolshevism, to isolate it, to circumscribe it, and to exterminate it. The Constitution of the League of Nations ignores this problem. Some of its advocates even seem to dally with it, and would be willing to make terms with it.

Two obvious duties lie before the Entente Allies: first, to destroy, not Germany, but German militarism, by imposing a peace of victory over militarism through geographic limitation under conditions of disarmament; and, second, to reinforce that limitation through geographic circumscription, by the formation of new independent States, so as to create a barrier on the East and Southeast against the German appropriation of Russia. The order of the day should be, first peace, and then an affirmation of the restored existence of a Society of States based on their inherent rights under International Law, with a pledge to respect, improve, and apply it judicially.

If the conflict with Germany were ended, an understanding between the Powers now 250 


\section{THE DÉBÂCLE OF DOGMATISM}

deliberating at Paris and a united effort tc respect and defend International Law if again violated, would go far toward securing the peace of the entire world for some years to come. Instead of allowing Bolshevism to spread, and permitting Germany to enter into alliance with it until she can appropriate its spoils, a new order of normal State existence should be aimed at, in which an assenting Germany can participate before she is destroyed.

When peace is once established, it is the Society of States, not a defensive League within it, likely to be counterpoised by another political combination of the same kind, that should be instituted. But this is not the work of war. It is essentially a work of peace, to be elaborated in a time of peace. The first condition of it is not a self-protective and dominant League; but an open forum, where the small States, unintimidated, may freely voice their necessities, not to a junta of Great Powers, but to the world at large; which will then quickly discover which nation is deserving of aid and sympa251 


\section{PROBLEMS IN FOREIGN POLICY}

thy. For this the Constitution of a League of Nations makes no provision. It demands that we shall walk by faith and not by sight; and that we shall place our faith not in open discussion, not in the disinterested judgment of mankind, but in the wisdom, the virtue, and the unselfishness of an international $\mathrm{im}$ perium, constructed and designed primarily to secure its own immunity by maintaining a predominant collective force, and secondarily to convert the small States into virtual protectorates under its own laws.

Instead of a directory in Paris, working in camera, hedged about with secrecy, forming new nations out of the débris of these disintegrated empires, and setting up a separate and exclusive control by Great Powers, the appeal should be to the smaller States and to the newly liberated nationalities to express their desires and preferences, and together to unite in determining their own future destinies. They should be told: We shall now treat and help you as free peoples. We ask you to cease fighting and choose your own representatives. We shall aid you 


\section{THE DÉBÂCLE OF DOGMATISM}

as far as we can in securing an adjustment of your differences and shall respect your self-determination, but we must do this impartially in response to your wishes. We shall open the ways of communication and commerce, but if you fight it will be at your own peril and the effect of your quarrels will be to close the avenues of trade.

This is not the manner in which the Conference at Paris is proceeding. It is a secret conclave, conducted by a Supreme Council composed of Great Powers, with a growing tendency to leave all decisions to the "Big Four." It is reconstructing Europe in its own way, and presumably in its own interest. It proposes a close corporation for the future, acting in secret, to secure its own peace and dictate the peace of the world upon the basis of a map of its own making. The Great Powers claim to be just, virtuous, and even benevolent, and perhaps they are, but the Holy Alliance a hundred years ago also claimed the noblest intentions.

It is interesting to note how democracy, in the end, has usually inadvertently played 


\section{PROBLEMS IN FOREIGN POLICY}

into the hands of autocracy, and confided its destinies to a single dominant will. When the Directory was formed at Paris, in the French Revolution, and the directors met to fortify their control, their first thought was of organization; but at their first meeting it was observed that it was unnecessary;Bonaparte had already taken his seat at the head of the table! No one disputed his right to remain there. Was he not necessary to the cause? Had he not fought successfully the battles of democracy? Democracy, it appeared, could not be imperilled by its most valiant apostle.

The small States-the truly democratic States-wait in the anteroom while the "Big Four" decide the fate of Europe. The Council, when the League is adopted, is to take their place. Democracy will, of course, be safe; for our President is named in Article $\mathrm{V}$ of the Covenant as the person to summon the first meeting of the Assembly, and of the Council. He, of course, represents democracy,-at least the type of democracy which 254 


\section{THE DÉBÂALE OF DOGMATISM}

he represents. We shall in time, perhaps, learn more fully what it is.

There might, however, in the interest of democracy, be some additional assurance in the Covenant of the League of Nations itself; but, when we examine it, we find that it contains no declaration of principles which the members are pledged to respect and support. There is no Bill of Rights, defining the essential and immutable prerogatives of sovereign States, - not a word in the entire document to indicate that States possess any inherent and sovereign rights whatever. Nothing is said of the right of "self-determination," nothing of any rights as belonging to the "people" anywhere. The whole document is devoted to the interests of Governments. There is no indication even of any right in any people to be directly represented in this corporation of State interests. The only reference to the people in this Covenant, aside from the power and prerogatives of States and Governments, is in Article XXIII, which promises to establish a permanent Bureau of Labor, with implicit 


\section{PROBLEMS IN FOREIGN POLICY}

power to regulate the conditions of industry, "both in their own countries and in all countries to which their commercial and industrial relations extend"; that is, it would appear, to prescribe the conditions of labor in all the countries of the world, whether members of the League or not.

The most pernicious vice in the system of ideas upon which this League is founded is that peace can be secured, without the existence of immense armed forces, by artificial lines drawn on a map.

A great force of cartographers has been employed at Paris in dissecting out of the conglomeration of races the various nationalities, and circumscribing them by lines of geographic demarcation. The secret of peace does not lie in geography, but in institutions, political and economic. The one great lesson that constitutional self-government has taught is that peace and contentment are not created by geographic boundaries, but by just laws and the economic opportunities afforded under a good government. The precise delimitation of races in the Near 256 


\section{THE DÉBÂCLE OF DOGMATISM}

East,-the débris of the Turkish Empire, for example,-is a physical impossibility. There cannot be created a Czecho-Slovakia, a Jugo-Slavia, an Armenia, a Poland, or a Syria, where the population will be entirely homogeneous, without impracticable migrations. There will always be left enclaves or transfusions of distinct races. We should never dream of such an operation in the United States. We merge our population by our institutions. Given constitutional guarantees, representative government, and the abolition of hyphenism - that is, the total obliteration of race distinctions-and the problem of government is solved. If we undertook to set up in America the conception of race-nationality as a basis of government, we should plunge this nation into civil war. And the attempt to do this in Europe will have no other result.

The whole conception of race-nationality is fallacious and involves a new danger. Its logical outcome is a struggle for race domination, as Pan-Germanism well illustrated. Wider territorial expansion was demanded, 257 


\section{PROBLEMS IN FOREIGN POLICY}

in order that a prolific race might always remain under the same political régime. This is the basis of the present efforts at scientific race cartography. It will prove illusory. It is for the peoples by choice and agreement to make the map, and not the ethnographers.

In the United States, and in America generally, no map has ever been made by a Supreme Council. The existing map has been made by the peoples who inhabit this continent, or by negotiation with other peoples; not always without conflict, but always followed with consent. It may not be a perfect map, but it is more generally assented to than one which a Supreme Council could have imposed. We, in America, have protected our sister republics from foreign intervention, but we have never pretended to portion out the continent among them.

The principle followed in constituting the new nationalities and fixing their frontiers is of importance chiefly in its relation to future peace. Unless they are satisfied there will be continued rivalries and possible conflict. If Article $\mathbf{X}$ is retained in the Consti258 


\section{THE DÉBÂCLE OF DOGMATISM}

tution of the League of Nations, there can be no change in the map when once the Constitution is adopted. Self-determination, so far as national allegiance is concerned, will then be finally repressed. If it is to have any recognition, it must be respected now; if not, all the members of the League will be arrayed against freedom and compelled to defend by force mistakes that might have been avoided.

By whatever standard we judge it, it is evident that the League of Nations, in proportion as it is to be real, is not the ultimate international ideal. It is, and by its essential nature must be, a combination of Powers within the wider Society of States. So far as the President of the United States is concerned with it, it was appealed to as a compromise expedient in the midst of war, in order to provide a means of reconciliation between the Entente Allies and the Central Powers. That was the purpose of the fourteen rubrics, and the League of Nations is merely the vehicle for enforcing them.

But the problem now is not reconciliation, 259 


\section{PROBLEMS IN FOREIGN POLICY}

and it never was. The real problem was and is to show the Central Powers, and particularly Germany, that ruthless aggression and violation of the Law of Nations cannot be tolerated, and cannot escape a just punishment. The whole future of the Society of States depends absolutely on that. There must be a peace of victory and not a peace of compromise, or there will never be any sure peace in the world.

The President has never entertained this idea. He still holds to his fourteen points of compromise as the only ground of reconciliation with criminal nations. If there is to be any safety in the future, they must cease to be criminal and pay the penalty of their crimes. After that they can take their places, if they confess and abandon their faults, in the free and responsible Society of States.

The idea of the League has been to bring them into it upon a basis of equality in the treaty of peace itself. That is why the Constitution of the League and the treaty of peace were to be so interwoven and compact260 


\section{THE DÉBÂCLE OF DOGMATISM}

ed that they could not be separated, and that no nation could make peace without accepting the League. If Germany signed that treaty, she also would accept the League; and, having accepted it, with all its obligations, why should she then not become a member of it?

That, in brief, is the whole content of the dogma of the League. If Germany and other nations were really penitent, really virtuous, really minded to submit to International Law, to respect it, and to maintain it, the League would be a superfluity. But if Germany and other nations are not so minded, then they have no proper place in it; and such a place should not be prepared for them.

Finally, the President's dogma breaks on the determination of the Entente to remain an entente, no matter by what name it is called. The basis of that Entente was and remains that the aggressor must be defeated and punished for crime, not welcomed into a fraternity of equals. Unless the President accepts that conclusion, he and the Confer261 


\section{PROBLEMS IN FOREIGN POLICY}

ence at Paris have nothing in common. If he does accept it, the League, as it must be amended before it can be adopted, is in its essence nothing but a written form of an understanding for mutual defense against an enemy not wholly overcome. If the enemy had been made to acknowledge defeat at the moment when he really was defeated, all this circumlocution would have been avoided. The Entente would have obtained la victoire intégrale and a chastened Germany would now be rehabilitating her national life, as it is her right and duty to do, in order to sup press Bolshevism instead of allying herself with it, and preparing to take a normal and useful part in the Society of States. 


\section{VIII}

THE PRESIDENT'S CHALLENGE TO THE SENATE

At Paris the President of the United States has had considerable apparent success in securing the embodiment of his own personal terms and at least a part of his plan for a League of Nations in the treaty of peace prepared by the Entente Allies. The reason for this is obvious. The United States was necessary to a victorious conclusion of the Great War, and it is equally necessary to the future maintenance of peace. Representing in his own person, as it appeared, the future policy of America, it was possible for the President at any time to order his ship, to abandon the Conference, and to leave the Entente Allies to face Germany alone. That decision would have created a great embarrassment for the exposed countries like Belgium and France. Such a desertion, 263 


\section{PROBLEMS IN FOREIGN POLICY}

it is true, would not have met the approval of the American people, but they would have been powerless to avert its consequences.

When the President, after his brief visit to the United States, returned to Paris to resume negotiations in the Conference, he found that in his absence great progress had been made toward the completion of a treaty that would end the long suspense and bring the war to a formal conclusion; but this treaty did not contemplate the inclusion of the Constitution of the League of Nations. The President had, however, thrown down to the Senators who had declared their unwillingness to ratify the Constitution of the League as it had been presented to them a challenge which he intended to carry out. ${ }^{1}$ "When that treaty comes back," he had said in his address in New York, on March 4th, "gentlemen on this side will find the covenant not only in it, but so many threads of the treaty tied to the covenant that you cannot dissect the covenant from the treaty with-

${ }^{1}$ For the declaration of the Senators, see the "Round Robin" at the end of this volume. 


\section{PRESIDENT'S CHALLENGE TO SENATE}

out destroying the whole vital structure."

Thirty-nine Senators, elected by the people, representing more than two-thirds of the entire population of the United States, were thus virtually informed that the "advice and consent" of the Senate would receive no consideration. They might, if they chose, privately regard the Constitution of the League of Nations as a defiance of their judgment and even a violation of the fundamental law of the Republic, which they had solemnly sworn to defend, but they would find themselves placed in a position in which they would have to accept this document as it had been formulated, without alterations, or they would be compelled to bear the odium of preventing the conclusion of peace, because the League of Nations would be an essential part of the peace treaty.

It is not necessary to dwell upon this defiance of the constitutional division of the treaty-making power and of the purpose with which that division was originally made and should always be maintained. This defiance assumed what every autocratic usur265 


\section{PROBLEMS IN FOREIGN POLICY}

pation of authority assumes, namely, that power could be invoked to sustain it. In this case it would no doubt be an attempt, in the nominal interest of peace, to bring political pressure to bear upon refractory Senators, in order to compel them to yield to a superior will. It requires no reflection to perceive that if this were done and were successful, it would mark the extinction of representative and even of constitutional government in the United States. That it was ever even contemplated indicates a departure from the principles on which our government is based which should awaken a deep concern for the future and call attention to the perils of autocratic as distinguished from representative democracy.

How serious the incident is from this point of view becomes clear when we compare the status of the American representation in the Peace Conference with that of any other of the Great Powers. In that conclave, the United States is the only country not represented by a single person confirmed by the legislative branch of Government; 266 


\section{PRESIDENT'S CHALLENGE TO SENATE}

and yet that body, negotiating in secret, has formulated a compact which, if adopted, is to become under our Constitution "the supreme law of the land." The treaty which is to contain this supreme law, it has been declared by the President of the United States, is to comprise matters foreign to its main purpose which cannot be separated from it, and upon which the legislative half of the treaty-making power is not to be permitted to exercise its untrammeled judgment.

It is in this connection important to note that while the "plenipotentiaries" of the United States in the Peace Conference have no legislative authority and derive their powers solely from the Executive, none of them having been confirmed by the Senate, all the representatives of the European Powers in the Conference are subject to recall by the legislative branch of their governments if their actions in the course of the negotiations are not approved. In order that approval or disapproval may be intelligently expressed and in a timely manner, 267 


\section{PROBLEMS IN FOREIGN POLICY}

the legislatures insist that they be kept informed of the course taken; and, as an example of this surveillance, it may be noted that the British Premier found it necessary to return in person to London, in order to explain to the House of Commons the attitude he had taken on behalf of his government in a matter of interest to them. And the Italian Premier did the same.

No European Premier, the head of a responsible government, would for a moment venture to ignore the advice of the legislative body upon which his official existence is dependent, much less to attempt to force its hand by embodying in a treaty anything which he had occasion to believe would not meet with its approval. If he should be so rash as to do so, he would be immediately withdrawn from the negotiations and another would be substituted in his place.

It was certainly never intended by the founders of the American Republic that the vital questions of foreign policy and international engagements should be subject to decision by a single person. If the precau268 
tions taken to avoid that result are lightly to be set aside and ignored, and especially if the voice of the people should proclaim a preference for that method of procedure, the United States would at once take rank as the least democratic nation in the world, and there would be new evidence that a democracy unrestrained by law is the inevitable victim of autocracy.

Whatever the attitude of the majority of the people may be in this matter-and it would be a serious reproach to them to suggest that they would approve the suppression of freedom in their representativesthe real issue created by the purpose to force acquiescence is not the ratification or nonratification of a particular treaty but the attempt of the Executive to dominate the legislative branch of the Government.

The strongest argument for a League of Nations thus far advanced is that it would offer an opportunity for conference and discussion, the idea being that by this means good understanding would be promoted. The effort to force the action of the Senate by 269 


\section{PROBLEMS IN FOREIGN POLICY}

combining the League of Nations with a treaty of peace for the purpose of preventing the separate examination of the project of a League on its merits, is a sad commentary on the prospect of free conference and discussion when the project is adopted.

The Senate has the constitutional right to withhold its consent from a treaty of which it does not approve. It may withhold it completely or in part. Possessing the right of amendment-which is in effect a conditional ratification-it has a ready defense against any attempt to force its decisions. There can be no intertwining of engagements which it cannot unravel. It can ratify a treaty of peace and at the same time reject a compact for a League of Nations. It would then remain for those responsible for the negotiation of a treaty designed to frustrate the judgment of the Senate to obtain the acceptance of the changes which the amendments might require.

Two courses, in such a situation, would be open. The President might refuse to act any further, or he might consent to reopen 


\section{PRESIDENT'S CHALLENGE TO SENATE}

the negotiations for the purpose of securing agreement on the changes. In the first case, the responsibility for the delay of a formal conclusion of peace would evidently rest upon those who had concluded a treaty which they knew beforehand would not be acceptable to a body necessary to ratification.

In the second case, the signatory Powers could not consistently refuse to separate what they had themselves intended not to join together, until the President forced them to do so; for they were prepared to postpone the League of Nations and sign a preliminary treaty of peace when the President returned to Paris from his visit to America and changed their plans. The embarrassment of asking for a reversal of a course upon which the President had himself insisted would no doubt be for him very great, but the alternative to resorting to it would be a clear responsibility for the failure of the peace negotiations. Whatever course might be followed as a consequence of the Senate's insistence upon its constitu271 


\section{PROBLEMS IN FOREIGN POLICY}

tional right, it is inconceivable that four, or ten or any other number of delegates sitting in council at Paris could frame any document on any subject which the Senate of the United States could be forced by the Executive to adopt against the better judgment of its members. If the people of the United States, for any reason whatever, arbitrarily insisted upon that, it would mark the end of the Republic.

From the beginning it was made clear that the Senate of the United States would not ratify any treaty which created a supergovernment; that is, a government that rendered the Government of the United States in any way subordinate to it.

Immediately there began a series of extenuations regarding the purport of the Constitution of the League. The representations of Senators regarding it were repudiated as "bogies." Far from the Constitution creating a supernational government, it was declared by its advocates, it was only an agreement to listen to "recommendations," not necessarily to follow them. In the cases 272 


\section{PRESIDENT'S CHALLENGE TO SENATE}

where the Constitution seemed to call for war, in order to impose peace, it remained for the separate governments to declare war, or not, as they might deem best. Thus, it turned out that, if this interpretation was correct, it was the League itself that was the real bogie;-a device not to enforce peace by an international army but by sheer intimidation, pretending to show a mailed fist but in fact merely shaking a finger at a possible aggressor.

It was a difficult task to mediate between these extreme interpretations, that of a super-government and that of an unaffected sovereignty. Some middle ground was even more necessary to the theory of the League to Enforce Peace than it was to the President's conception of a league which should aim to "insure" peace; a result which, he thought, might be accomplished without force if the intimidation imposed were suificiently impressive.

It was upon the President of the League to Enforce Peace, Ex-President William Howard Taft, therefore, that the task chief273 


\section{PROBLEMS IN FOREIGN POLICY}

ly fell, by the use of his great prestige and his dialectical skill, to reconcile the Constitution of the League to the Constitution of the United States. Coming from him, almost any assurance seemed to many citizens a sufficient guarantee that the conflict between the two "constitutions" was purely imaginary, which makes it of importance to know what the former President's position was regarding the obligations of the League.

Answering the argument of Senator Knox, the Ex-President, in his speech before the Economic Club of New York, parried the accusation regarding super-government in the following adroit manner:

"When Senator Knox's attack upon the coveriant is analyzed, it will be seen to rest on an aisumption that the Executive Council is given executive powers which are unwarrariced by the text of the covenant. 'sne whole function of the Executive Council is to be the medium through which the League members are to exchange views, the advisory board to consider all matters arising in the field of the League's possible 274 


\section{PRESIDENT'S CHALLENGE TO SENATE}

action and to advise the members as to what they ought by joint action to do.'

"The Council makes few, if any, orders binding on the members of the League. Where the Executive Council acts as a mediating and inquiring body to settle differences not arbitrated, its unanimous recommendations of a settlement must satisfy the nation seeking relief, if the defendant nation complies with the recommendation. All other obligations of the United States under the League are to be found in the covenants of the League, and not in any action of the Executive Council. When this is understood clearly the whole structure of Senator Knox's indictment falls."

The argument here is that the Executive Council is a purely "advisory" body, without any power to command. The obligations of the United States therefore, are not to be found in the action of the Council, but solely in "the covenants of the League." These covenants, being freely made, it is held, are in no sense infractions of sovereignty. On the contrary, they are affirma- 


\section{PROBLEMS IN FOREIGN POLICY}

tions of it. They are voluntary agreements.

The answer to Senator Knox then reduces itself to this: that there is in the Constitution of the League as originally presented no element of a super-government. That the League, as such, can enforce nothing; and that the "recommendations" of the Executive Council are in no sense binding.

To verify this interpretation, the ExPresident quotes Lord Robert Cecil as laying down the principle "that all action must be unanimously agreed to in accordance with the general rule that governs international relations;" adding, that "this interpretation by one of the most distinguished draftsmen of the League shows that all its language, reasonably construed, delegates no power to these bodies to act for the League and its members without their unanimous concurrence unless the words used make such delegation clear." It is interesting, however, to observe that Ex-President Taft has proposed four amendments to the original draft of the Constitution of the League, the third one "definitely stating the rule of unanimity 276 


\section{PRESIDENT'S CHALLENGE TO SENATE}

and making it perfectly plain that any action taken by the Executive Council of the League must be unanimous, thereby necessitating the concurrence of the American Government's member of the Executive Council before its action could be binding upon the United States." 2 This amendment has been accepted, and to that extent the League becomes an Entente.

It is not possible, however, thus easily to destroy the argument of Senator Knox. The fact that Mr. Taft finds it desirable to make sure of the unanimity of the Executive Council before it can even be allowed to "recommend," shows that there is lodged within it some potency against which it is necessary to guard. It cannot be overlooked that Article I, creating the Executive Council, makes it the "instrumentality" through which "action shall be effected." That is why it was called and still is an "Executive" Council, although the word "Council" is now unqualified. It has important functions to perform. When the

${ }^{2}$ For the amendments, see, at the end of this volume, a list of the amendments proposed 


\section{PROBLEMS IN FOREIGN POLICY}

allotment of armament has once been made, the scale of forces cannot be exceeded "without the concurrence of the Council" (Article VIII), and under the rule of unanimity one single member could prevent a State from increasing its means of defense. The Council is to "advise" upon the means by which the obligation to protect territorial integrity and political independence, under Article $\mathrm{X}$, shall be fulfilled. If this advice involves a declaration of war, the governments advised to make a declaration may indeed refuse; but they would in that case be regarded as delinquent. Under Article XVI such a member may be expelled from the League; and a member may not voluntarily withdraw on two years' notice unless "all its obligations under this Covenant have been fulfilled at the time of withdrawal" (Article I). A worse situation would arise if the opposition of a member of the Council should nullify any action whatever, and thus completely paralyze the League. When the Council, acting as a judge, makes a recommendation, under Article XII, compliance 278 


\section{PRESIDENT'S CHALLENGE TO SENATE}

with the award by one party binds the other to accept it; and, under Article $X V$, if any party shall refuse so to comply, "the Council shall propose the measures necessary to give effect to the recommendation." Under Article XVI, the Council is to recommend "what effective military or naval force the members of the League shall severally contribute to the armed forces to be used to protect the covenants of the League." Under Article XVII the Council may coerce States not members of the League, and under Article XXII it exercises sovereign rights through its mandates to members of the League. It is true that all these powers are expressed in terms of invitation rather than terms of command, but unless the Council is regarded as acting with authority it is difficult to see that there is any provision for the effective enforcement of peace or of any covenants whatever.

There remain, however, the "obligations of the Covenant"; and it is upon these that the Ex-President lays the whole burden. The treaty-making power, he holds, - that 279 


\section{PROBLEMS IN FOREIGN POLICY}

is, the President and Senate,-is empowered by the Constitution of the United States to make treaties, which "enables them to bind the United States to a contract with another nation on any subject usually the subject matter of treaties between nations, subject to the limitation that the treaty may not change the form of the government of the United States. ... It therefore follows that whenever the treaty-making power binds the United States to do anything it must be done by the branch of that government vested by the Constitution with that function." This is to say that when the treatymaking power engages to make war, to raise armies and maintain navies, or not to raise armies and maintain navies, or to do anything which the Constitution empowers Congress to do, Congress must do it, and has no choice, except to take notice that the obligation has fallen due and action must be taken.

Thus Mr. Taft very ingeniously takes away from the Council of the League all the attributes of a super-government only to 280 


\section{PRESIDENT'S CHALLENGE TO SENATE}

include them in the "obligations of the Covenant" created by the President and Senate of the United States.

That the Constitution of the League thus creates a super-government, that is, a form of authority under which the Congress of the United States is compelled to act when the casus foederis calls for its action, must be candidly admitted. Senator Knox finds this compulsion in the Council, the "instrumentality through which the League's action is effected." Mr. Taft finds it in "the obligations of the Covenant." In either case, the result is the same. The League binds Congress to declare war, raise and expend money, and do many other acts, not when Congress in its own judgment considers them timely and necessary, but when the "obligations of the Covenant" require it.

These obligations, the Ex-President not only admits but asserts, are commands to Congress to act in the way they prescribe. Who then creates these obligations? The President of the United States thinks they can be created by himself alone through his 281 


\section{PROBLEMS IN FOREIGN POLICY}

influence at Paris, and that the Senate can then be forced to accept them whether the senators wish to do so or not. The ExPresident of the UnitedStates does not go so far as this. He considers it necessary for the whole treaty-making power to create these obligations, but he believes that the President and Senate together can create them; and that, having done so, the Congress of the United States must act when the obligations fall due, and will have no freedom beyond the recognition of the fact that the time has arrived for the fulfilment of the obligations thus created. The Council will "advise" the Congress of this and "recommend" its action. The only escape from action would be either an attempt on the part of Congress to prove that the Council was misinterpreting the treaty or the failure of our Government to respect it.

In such circumstances is it reprehensible that the Senate of the United States should wish to consider with great care the nature of the obligations to be undertaken, and should refuse to be forced into acquies282 


\section{PRESIDENT'S CHALLENGE TO SENATE}

cence by an executive demand that all "expediency" is to be disregarded?

Objections to the original proposal accepted at Paris were raised by members of all political parties in the United States. It is futile, therefore, to regard criticism of the Constitution of the League as a partisan opposition. Its most ardent advocate, for reasons which are obvious, has been ExPresident Taft. Although committed $a$ priori to the formation of a "League," there were, nevertheless, modifications which he as well as others considered it desirable to make respecting the engagements of the United States. The first relates to the Monroe Doctrine, consisting of an amendment making reservations to safeguard it; the second to secure any country in the League the right to control matters solely within its domestic jurisdiction, such as the question of immigration; and one to provide for a withdrawal from the League of Nations, and possibly for a definite term of the existence of the League itself. It is noteworthy that all these changes are in the direction of re283 


\section{PROBLEMS IN FOREIGN POLICY}

stricting the power and limiting the duration of the League.

Other eminent American statesmen also have suggested improvements in the Constitution of the League as originally proposed. ${ }^{3}$ All of them unite in demanding the retention of the Monroe Doctrine. Upon this point Mr. Charles Evans Hughes and Mr. Elihu Root have been particularly explicit in counselling that it be made clear that no obligation assumed by the United States shall imply the renunciation of its time-honored policy with regard to strictly American questions.

This earnest expression of solicitude has produced an effect at Paris, but the result has occasioned bewilderment. It has never been considered that the Monroe Doctrine is to be classed with international engagements, treaties of arbitration, or regional understandings for securing the maintenance of peace; and the amazement was therefore great when the public was informed that to.

${ }^{8}$ See at the end of this volume the amendments referred 284 


\section{PRESIDENT'S CHALLENGE TO SENATE}

Article X, which pledges the members of the League "to respect and preserve as against external aggression" one another's "territorial integrity and existing political independence," was to be amended by the addition of the words:

"Nothing in this covenant shall be deemed to affect the validity of international engagements, such as treaties of arbitration or regional understandings like the Monroe Doctrine, for securing the maintenance of peace," which now appear as Article XXI in the revised covenant.

It is proudly announced that at last, in the midst of much opposition and by great efforts, the President succeeded in securing the recognition of the Monroe Doctrine as a part of International Law! It seems rather disingenuous, after heralding the League as itself an extension of the Monroe Doctrine to all the world, as the President has done, that he should make a struggle for its inclusion in this treaty, and in such a form! That the President should ever have accepted the language of this amendment, which it is al285 


\section{PROBLEMS IN FOREIGN POLICY}

most inconceivable that any American could have written, as a characterization of $\mathbf{a}$. policy of the United States, which is neither a law, nor an international engagement, nor a regional understanding, but simply and solely a political policy, is certainly surprising.

It is doubtful if the presence of these strange words in the Covenant of the League can ever transform a purely national policy into International Law, which would only denature it. It requires no sanction by a lawmaking body, and if it did the Conference at Paris could not give it. It is a life principle of the American Republic, and means two things: first, that no foreign Power shall ever acquire a foothold on this continent that would menace the security of this nation; and, second, that this nation will never imperil its own existence by intervention in non-American affairs.

Never before the Great War had it been necessary for the United States to fight in Europe for its own rights, but the ambitions and methods of the Imperial German Gov286 


\section{PRESIDENT'S CHALLENGE TO SENATE}

ernment created that necessity. We have in this war fought for Belgium, for France, for Great Britain, and other nations because they were fighting for us, and we shall do so again if our common enemy renews the attack; but we have never yet been committed to a pledge to fight for everybody everywhere. The Monroe Doctrine has remained until now an uncompromised national policy, and it should be permanently maintained in its twofold meaning as a prohibition of foreign intrusion on the American continent and as a limitation of responsibility in other parts of the world.

The amendment as it stands in the revised Covenant does not express this intention. Article XXI has more appropriate application to the secret treaty of London, which the President repudiates, than it has to the Monroe Doctrine; for the secret treaty of London was a "regional understanding," while the Monroe Doctrine is not. The form of reservation attached to the Hague Conventions was explicit and accurate, ${ }^{4}$ and

${ }^{4}$ See the text of this reservation at the end of this volume. 287 


\section{PROBLEMS IN FOREIGN POLICY}

might well, with slight modification, be attached to the present treaty, which would be in the spirit of Mr. Root's third and Mr. Hughes' third and fourth proposed amendments.

Mr. Root further suggests, in his sixth amendment, the calling of a general conference of the members after five or ten years to revise the Covenant, after which any member, on a year's notice, may withdraw from the League; and Mr. Hughes would make provision that any member may withdraw "at its pleasure on specified notice," instead of after two years' notice of its intention to do so, as provided in the revised draft of Article I. He also proposed that no member shall be constituted a mandatary without its consent, which has been accepted, and that no European or Asiatic Power shall be constituted a mandatary of any American people.

Even as thus modified, the League would be far from the realization of the highest international ideals. It has been pointed out that the Covenant neither recognizes as bind288 


\section{PRESIDENT'S CHALLENGE TO SENATE}

ing the rules of International Law nor makes provision for the improvement of them. As a limited corporation in the general Society of States, it cannot claim universality or justly exercise lawmaking powers that all sovereign States would be bound to respect. It would be merely a single political organism in a community of jurally equal States. Other leagues might be formed which, even if they did not equal it in power, could claim an equal justification for their existence. They also would aim to be self-protective. In brief, even though the League were preponderant, it would not constitute the Society of States.

To prevent the continuance of what would thus remain at most a mere preponderance of power, Mr. Root has proposed in his second amendment a method of making the League the means of a transition to a real Society of Nations. His proposal, which was endorsed by the Executive Committee of the American Society of International Law and cabled to Paris, is as follows:

"The Executive Council shall call a gen289 


\section{PROBLEMS IN FOREIGN POLICY}

eral conference of the Powers to meet not less than two years or more than five years after the signing of this convention for the purpose of reviewing the condition of International Law, and of agreeing upon and stating in its authoritative form the principles and rules thereof.

"Thereafter regular conferences for that purpose shall be called and held at stated times."

This wise suggestion was not adopted at Paris; a fact which justifies the inference that the League intends to decide questions of International Law in its own way, and in accordance with its own corporate policies. In short, it intends to act imperially.

As an example of this, take the provision for determining whether or not a given question is one of domestic jurisdiction, like the tariff or the immigration question. Article $\mathrm{XV}$ reads: "If the dispute . . . is found by the Council to arise out of a matter which by International Law is solely within the jurisdiction of that party, the Council shall so report, and shall make no recommenda290 


\section{PRESIDENT'S CHALLENGE TO SENATE}

tion as to its settlement." But, it is immediately added, "The Council may in any case under this Article refer the dispute to the Assembly"; that is, even though the question at issue is under International Law a domestic one, upon which the Council made no recommendation, it could be referred to the Assembly for decision! The nature of the decision would then depend upon the policy which the Assembly chose to adopt. If the United States were a disputant, it would have no voice in the decision, which would be made by others, without reference to International Law, in accordance with their prevailing policies, whatever they might be.

Before entering into such bonds with foreign Powers, it is timely to consider the consequences of making engagements, nominally in the interest of peace, regarding matters which have no logical connection with a treaty of peace and are arbitrarily forced into it. It is inevitable that matters which we have always considered purely national will be treated by the League as inter291 


\section{PROBLEMS IN FOREIGN POLICY}

national. This is true of our foreign policy as a whole, which under the League would be equally the affair of all the members. Not even the Monroe Doctrine, which we have always considered peculiarly our own affair, would be exempted from this total surrender of national policy. In the British Memorandum, giving the views of London regarding the Monroe Doctrine, for example, that purely American policy is already treated as an "international understanding," to be interpreted and applied by the Council and the Assembly, and not any longer by the United States alone. "Should any dispute arise between American and European Powers," concludes this commentary, "the League is there to settle it."

After such an assumption as this what will remain, under this Covenant, of an independent American foreign policy? The powers which in the first draft of the Covenant were attributed to the Executive Council are in the revised document largely transferred to the Assembly. In that larger body the United States would have three repre292 


\section{PRESIDENT'S CHALLENGE TO SENATE}

sentatives, but only one vote. Among the "original members" of the League and separate "signatories of the Treaty of Peace," are specified, "the British Empire, Canada, Australia, South Africa, New Zealand and India." 5 These six members, with a close community of primary interests, would be entitled to eighteen representatives and six votes in the Assembly, while the United States, which has a greater self-governing population than all of these imperial dominions combined, would have only three representatives and only one vote.

It is an unwelcome task, in view of the close friendship that should exist between the United States and Great Britain, to call attention to this disparity; for real friendship never anywhere long continues in the presence of doubt as to perfect freedom and perfect equality. For common interests and common purposes the United States and Great Britain - which have so much in common-should act together; but it must not

${ }^{5}$ See the Annex to the Revised Covenant at the end of the volume. 


\section{PROBLEMS IN FOREIGN POLICY}

be overlooked that the British Empire has interests and policies which the United States has never shared and has not always approved. As a people we have never regretted our separate and independent existence, and there are many millions of American citizens who will not submit to abandoning it now. Nothing could more fatally destroy the friendship of these two countries than a conviction that what was fought for and won in $\mathbf{1 7 7 6}$ is to be lightly surrendered in the floodtide of our national greatness at the end of a victorious war.

There are those who believe that at Paris American interests have been subordinated to foreign interests, in order to secure the success of the President's personal theories. They believe that he went to Europe to say in private what he did not wish to discuss in public; that he intended to establish a League that would make possible a compromise peace; that this League was originally intended to limit the supremacy of Great Britain on the sea, and thus placate the hostility of Germany; that France, as a 294 


\section{PRESIDENT'S CHALLENGE TO SENATE}

means of obtaining future security, could be made to enter such a League along with Germany; that, upon these conditions, a general reciprocal guarantee of territory could be obtained, and that the rivalries of trade could in future be avoided by "the removal of all economic barriers and the establishment of an equality of trade conditions among all the nations consenting to the peace and associating themselves for its maintenance." 8

To carry this theory into effect, it was necessary to interweave the treaty of peace with the formation of a League in such a manner that all who desired peace,-for it was certain that all the belligerents wished for peace as soon as possible,-would be forced to accept the League, whether they desired it or not; for the League thus organized was to create a new international order, which the President believed would put an end to war, and be the greatest achievement in history.

- See number 3 of the Fourteen Points at the end of this volume. 


\section{PROBLEMS IN FOREIGN POLICY}

Without discussing in a critical spirit the character of the motives of this great enterprise, it is clear that the execution of this purpose involved secrecy, opposition to a prompt peace of victory, negotiation with adverse national interests, and some concessions for the purpose of winning adherents.

It will probably be many years before the conversations of the Supreme Council of Ten, the "Big Four" and the "Big Three" will become known to the public, and some of them will perhaps never be known or be variously reported in memoirs and autobiographies. The participants will no doubt have for a long time a certain control over one another.

It was pointed out in a friendly spirit before the President went to Europe, that by appointing himself as first delegate and repudiating written instructions to intermediaries, he was risking the charge of secret diplomacy and the deliberate abandonment of the idea of covenants "openly arrived at."

The Senate of the United States, if the ordinary course had been adopted, would be 296 


\section{PRESIDENT'S CHALLENGE TO SENATE}

in a position to know from records what was the actual course of negotiation. In the absence of this, unless the President wishes personally to submit to interrogation, there is room for a wide scope of inference regarding the bargains made to secure the League.

There are those who will wonder why the alleged American plan of a League has never been published; who will infer that it was rejected or withdrawn because it was needful to adopt a more flexible trading programme; and who will think that the Smuts plan was adopted because without concessions to Great Britain there could have been no League, and without a league of some kind the Great Mission would have been a failure.

One might imagine the British Premier as saying: "There is already a League of Nations. The British Empire is such a league. If you will model the League on that, as General Smuts suggests, we might regard it favorably. Of course we must retain our sea-power. Unless you will pledge the large navy you are developing in the 297 


\section{PROBLEMS IN FOREIGN POLICY}

United States to the defense of the Empire, we must defend ourselves. Of course under the League, the rights of neutrality, to which you have held so closely in the past, would no longer exist. If you will help us out with mandataries and defend our imperial possessions from future attack, perhaps we can arrange for a League."

"But by this plan, what advantage does the United States get?"

"Why, Mr. President, you get the League!"

With France negotiations were, perhaps, less complicated, for without some special provision, even after peace was signed, France would be unprotected. One can imagine a question to Monsieur Clemenceau: "Where will France look for protection, if not to the League?"- "To the honor of her co-belligerents." - "But would not the mutual guarantees of the League be sufficient?" "With Germany a League is impossible." "What then do you expect?" - "We expect a separate defensive alliance; for the League does not afford security for France. If you 298 


\section{PRESIDENT'S CHALLENGE TO SENATE}

have the League, we must have the separate alliance."

And so, even without documents, the logic of the situation renders it not difficult to understand what has happened at Paris; why the League was always, except in America, regarded and spoken of as 'l'idée Américaine;" and also why the League had to be intertwined inextricably with the long deferred and much desired treaty of peace, in order to force the hand of the Senate.

Acting by itself, the Senate of the United States would probably regard the prestige of reorganizing the world on paper as bought at too high a price by the acceptance of the responsibilities of Article $\mathbf{X}$ and American participation in the international political trust that is to issue "Acts and Charters" for the sovereign rule of countries and colonies in Europe, Asia, and Africa with which the United States, as a constitutional selfgoverning nation, has no right of interference.

However the Senate may regard the President's challenge, it cannot escape re299 


\section{PROBLEMS IN FOREIGN POLICY}

sponsibility for its decision. There is one aspect of the subject of the highest importance to the future of the American Republic that has been left in obscurity by nearly all who have commented on the proposed League, namely, the joint imperialism which it establishes. This, though overlooked in America, is well understood in Great Britain, and preparations are making to render it effective. General Smuts, who is a practical officer, recognizes that it is necessary for the League "to train big staffs to look at things from a. large human, instead of national point of view." The Grand Secretariat now being organized in London, under the direction of Sir James Eric Drummond, of the British Foreign Office, will be the school in which the international bureaucracy will be formed and tempered to its task. Viscount Grey sees a great future for this super-national rule of the world under benevolent experts. "I don't see," he said, "why the League of Nations, once formed, should be necessarily idle." Nor would he leave it without means of action. "I don't 300 


\section{PRESIDENT'S CHALLENGE TO SENATE}

see why," he continued, "it should not be arranged for an authoritative and an international force to be at its disposal, which should act as police in individual countries."

It is this that makes the acceptance of a place in the League by the United States so imperative for its success. This policing of the world requires men and money. America has both. Europe's answer to America's great idea of a League is : "We accept it with pleasure. Now stop the fighting that has not ceased from Finland to the Crimea, while the Peace Conference has been in session. We have our own idea of these things based on a long experience. We will try your plan; but in the meantime you must make the Turk spare the Armenian, a mutilated Poland be satisfied with its lot, keep the Hungarians and the Roumanians quiet on the Theiss, settle the disputes of the Italians and the Jugo-Slavs in the Adriatic, make Persia a safe place to live in, and keep Germany within bounds. Unless your League can do these things, it has not helped us much, but if it does them it will be chiefly at 301 


\section{PROBLEMS IN FOREIGN POLICY}

your expense; for we must put our house in order and pay our debts while we guard our frontiers. We have not asked you for a League. We are interested in our own national life. We have consented to the League, but we have never much believed in it. Now let America show us that it will work."

And the Senate will have to answer to the country for the engagements it ratifies. 


\section{DOCUMENTS}

\section{PRESIDENT WILSON'S "POINTS"}

\section{THE "FOURTEEN POINTS" OF JANUARY 8, 1918.}

1. Open covenants of peace, openly arrived at, after which there shall be no private international understandings of any kind, but diplomacy shall proceed always frankly and in the public view.

2. Absolute freedom of navigation upon the seas, outside territorial waters, alike in peace and in war, except as the seas may be closed in whole or in part by international action for the enforcement of international covenants.

[The allied Governments reserved to themselves complete freedom on this point, November 5, and stated their understanding that the word "restored" in the paragraph below dealing with invaded countries means compensation by Germany for damage to 303 


\section{PROBLEMS IN FOREIGN POLICY}

civilian population of the Allies and their property. To the latter point President Wilson formally assented.]

3. The removal, so far as possible, of all economic barriers and the establishment of an equality of trade conditions among all the nations consenting to the peace and associating themselves for its maintenance.

4. Adequate guarantees given and taken that national armaments will be reduced to the lowest point consistent with domestic safety.

5. A free, open-minded, and absolutely impartial adjustment of all colonial claims, based upon a strict observance of the principle that in determining all such questions of sovereignty the interests of the populations concerned must have equal weight with the equitable claims of the government whose title is to be determined.

6. The evacuation of all Russian territory and such a settlement of all questions affecting Russia as will secure the best and freest coöperation of the other nations of the world in obtaining for her an unhampered and unembarrassed opportunity for the independent determination of her own political development and national policy, and assure her of a sincere welcome into the society of free nations under institutions of her own choosing, and, more than a welcome, assistance also of every kind that she may need and may herself desire. The treatment accorded 


\section{PRESIDENT WILSON'S "POINTS"}

Russia by her sister nations in the months to come will be the acid test of their good will, of their comprehension of her needs as distinguished from their own interests, and of their intelligent and unselfish sympathy.

77. Belgium, the whole world will agree, must be evacuated and restored, without any attempt to limit the sovereignty which she enjoys in common with all other free nations. No other single act will serve as this will serve to restore confidence among the nations in the laws which they have themselves set and determined for the government of their relations with one another. Without this healing act the whole structure and validity of international law is forever impaired.

8. All French territory should be freed and the invaded portions restored, and the wrong done to France by Prussia in 1871 in the matter of AlsaceLorraine, which has unsettled the peace of the world for nearly fifty years, should be righted, in order that peace may once more be made secure in the interest of all.

9. A readjustment of the frontiers of Italy should be effected along clearly recognizable lines of nationality.

10. The peoples of Austria-Hungary, whose place among the nations we wish to see safeguarded and assured, should be accorded the freest opportunity of autonomous development. 


\section{PROBLEMS IN FOREIGN POLICY}

[On October 19, the President notified the AustroHungarian Government which had requested an armistice that certain conditions had changed since January 8. Quoting point 10, Secretary Lansing's note said: "Since that sentence was written and uttered to the Congress of the United States, the Government of the United States has recognized that a state of belligerency exists between the Czecho-Slovaks and the German and Austro-Hungarian Empires and that the Czecho-Slovak National Council is a de facto belligerent Government clothed with proper authority to direct the military and political affairs of the Czecho-Slovaks. It has also recognized in the fullest manner the justice of the nationalistic aspirations of the Jugo-Slavs for freedom. The President is, therefore, no longer at liberty to accept the mere 'autonomy' of these peoples as a basis of peace, but is obliged to insist that they, and not he, shall be the judges of what action on the part of the AustroHungarian Government will satisfy their aspirations and their conception of their rights and destiny as members of the family of nations."]

11. Rumania, Serbia, and Montenegro should be evacuated, occupied territories restored, Serbia accorded free and secure access to the sea, and the relations of the several Balkan states to one another determined by friendly counsel along historical established lines of allegiance and nationality, and international guarantees of the political and economic 306 


\section{PRESIDENT WILSON'S "POINTS"}

independence and territorial integrity of the several Balkan states should be entered into.

12. The Turkish portions of the present Ottoman Empire should be assured a secure sovereignty, but the other nationalities which are now under Turkish rule should be assured an undoubted security of life and an absolutely unmolested opportunity of autonomous development, and the Dardanelles should be permanently opened as a free passage to the ships and commerce of all nations under international guarantees.

13. An independent Polish state should be erected, which should include the territories inhabited by indisputably Polish populations, which should be assured a free and secure access to the sea, and whose political and economic independence and territorial integrity should be guaranteed by international covenant.

14. A general association of nations must be formed under specific covenants for the purpose of affording mutual guarantees of political independence and territorial integrity to great and small states alike.

THE FIVE POINTS OF SEPTEMBER 27, 1918. (Address at Metropolitan Opera House, New York)

As I see it, the constitution of that league of nations and the clear definition of its objects must be 307 


\section{PROBLEMS IN FOREIGN POLICY}

a part, is in a sense the most essential part, of the peace settlement itself. ... It is necessary to guarantee the peace, and the peace cannot be guaranteed as an afterthought.

First, the impartial justice meted out must involve no discrimination between those to whom we wish to be just and those to whom we do not wish to be just. It must be a justice that plays no favorites and knows no standard but equal rights of the several peoples concerned;

Second, no special or separate interest of any single nation or any group of nations can be made the basis of any part of the settlement which is not consistent with the common interest of all;

Third, there can be no leagues or alliances or special covenants and understandings within the general and common family of the league of nations;

Fourth, and more specifically, there can be no special, selfish economic combinations within the league and no employment of any form of economic boycott or exclusion except as the power of economic penalty by exclusion from the markets of the world may be vested in the league of nations itself as a means of discipline and control.

Fifth, all international agreements and treaties of every kind must be made known in their entirety to the rest of the world. 


\section{THE COVENANT AS ORIGI- NALLY AGREED UPON AT PARIS, FEBRUARY 14, 1919}

\section{PREAMBLE}

In order to promote international co-operation and to secure international peace and security by the acceptance of obligations not to resort to war, by the prescription of open, just and honorable relations between nations, by the firm establishment of the understandings of international law as the actual rule of conduct among governments, and by the maintenance of justice and a scrupulous respect for all treaty obligations in the dealings of organized peoples with one another, the Powers signatory to this Covenant adopt this constitution of the League of Nations.

\section{Article I}

The action of the High Contracting Parties under the terms of this Covenant shall be effected through the instrumentality of meetings of a Body of Delegates representing the High Contracting Parties, of meetings at more frequent intervals of an Executive Council, and of a permanent international Secretariat to be established at the Seat of the League. 


\section{PROBLEMS IN FOREIGN POLICY}

\section{Article II}

Meetings of the Body of Delegates shall be held at stated intervals and from time to time as occasion may require for the purpose of dealing with matters within the sphere of action of the League. Meetings of the Body of Delegates shall be held at the Seat of the League or at such other place as may be found convenient and shall consist of representatives of the High Contracting Parties. Each of the High Contracting Parties shall have one vote but may have not more than three representatives.

\section{Article III}

The Executive Council shall consist of representatives of the United States of America, the British Empire, France, Italy and Japan, together with representatives of four other States, members of the League. The selection of these four States shall be made by the Body of Delegates on such principles and in such manner as they think fit. Pending the appointment of these representatives of the other States, representatives of shall be members of the Executive Council.

Meetings of the Council shall be held from time to time as occasion may require and at least once a year at whatever place may be decided on, or failing any such decision, at the Seat of the League, and any matter within the sphere of action of the League or affecting the peace of the world may be dealt with at such meetings. 


\section{ORIGINAL COVENANT}

Invitations shall be sent to any Power to attend a meeting of the Council at which matters directly affecting its interests are to be discussed and no decision taken at any meeting will be binding on such Power unless so invited.

\section{Article IV}

All matters of procedure at meetings of the Body of Delegates or the Executive Council including the appointment of Committees to investigate particular matters shall be regulated by the Body of Delegates or the Executive Council and may be decided by a majority of the States represented at the meeting.

The first meeting of the Body of Delegates and of the Executive Council shall be summoned by the President of the United States of America.

\section{Article V}

The permanent Secretariat of the League shall be established at which shall constitute the Seat of the League. The Secretariat shall comprise such secretaries and staff as may be required, under the general direction and control of a Secretary-General of the League, who shall be chosen by the Executive Council; the Secretariat shall be appointed by the Secretary-General subject to confirmation by the Executive Council.

The Secretary-General shall act in that capacity at all meetings of the Body of Delegates or of the Executive Council. 


\section{PROBLEMS IN FOREIGN POLICY}

The expenses of the Secretariat shall be borne by the States members of the League in accordance with the apportionment of the expenses of the International Bureau of the Universal Postal Union.

\section{Article VI}

Representatives of the High Contracting Parties and officials of the League when engaged on the business of the League shall enjoy diplomatic privileges and immunities, and the buildings occupied by the League or its officials or by representatives attending its meetings shall enjoy the benefits of extraterritoriality.

\section{Article VII}

Admission to the League of States not signatories to the Covenant and not named in the Protocol hereto as States to be invited to adhere to the Covenant requires the assent of not less than two-thirds of the States represented in the Body of Delegates, and shall be limited to fully self-governing countries including Dominions and Colonies.

No State shall be admitted to the League unless it is able to give eff ective guarantees of its sincere intention to observe its international obligations, and unless it shall conform to such principles as may be prescribed by the League in regard to its naval and military forces and armaments.

\section{Article VIII}

The High Contracting Parties recognize the principle that the maintenance of peace will require the

$$
\text { sid }
$$




\section{ORIGINAL COVENANT}

reduction of national armaments to the lowest point consistent with national safety and the enforcement by common action of international obligations, having special regard to the geographical situation and circumstances of each State; and the Executive Council shall formulate plans for effecting such reduction. The Executive Council shall also determine for the consideration and action of the several governments what military equipment and armament is fair and reasonable in proportion to the scale of forces laid down in the programme of disarmament; and these limits, when adopted, shall not be exceeded without the permission of the Executive Council.

The High Contracting Parties agree that the manufacture by private enterprise of munitions and implements of war lends itself to grave objections, and direct the Executive Council to advise how the evil effects attendant upon such manufacture can be prevented, due regard being had to the necessities of those countries which are not able to manufacture for themselves the munitions and implements of war necessary for their safety.

The High Contracting Parties undertake in no way to conceal from each other the condition of such of their industries as are capable of being adapted to war-like purposes or the scale of their armaments, and agree that there shall be full and frank interchange of information as to their military and naval programmes. 


\section{PROBLEMS IN FOREIGN POLICY}

\section{Article IX}

A permanent Commission shall be constituted to advise the League on the execution of the provisions of Article VIII and on military and naval questions generally.

\section{Article $\mathrm{X}$}

The High Contracting Parties undertake to respect and preserve as against external aggression the territorial integrity and existing political independence of all States mimbers of the League. In case of any such aggression or in case of any threat or danger of such aggression the Executive Council shall advise upon the means by which this obligation shall be fulfilled.

\section{Article XI}

Any war or threat of war, whether immediately affecting any of the High Contracting Parties or not, is hereby declared a matter of concern to the League, and the High Contracting Parties reserve the right to take any action that may be deemed wise and effectual to safeguard the peace of nations.

It is hereby also declared and agreed to be the friendly right of each of the High Contracting Parties to draw the attention of the Body of Delegates or of the Executive Council to any circumstances affecting international intercourse which threaten to disturb international peace or the good understanding between nations upon which peace depends. 


\section{ORIGINAL COVENANT}

\section{Article XII}

The High Contracting Parties agree that should disputes arise between them which cannot be adjusted by the ordinary processes of diplomacy, they will in no case resort to war without previously submitting the questions and matters involved either to arbitration or to inquiry by the Executive Council and until three months after the award by the arbitrators or a recommendation by the Executive Council; and that they will not even then resort to war as against a member of the League which complies with the award of the arbitrators or the recommendation of the Executive Council.

In any case under this Article, the award of the arbitrators shall be made within a reasonable time, and the recommendation of the Executive Council shall be made within six months after the submission of the dispute.

\section{Article XIII}

The High Contracting Parties agree that whenever any dispute or difficulty shall arise between them which they recognize to be suitable for submission to arbitration and which cannot be satisfactorily settled by diplomacy, they will submit the whole subject matter to arbitration. For this purpose the Court of arbitration to which the case is referred shall be the court agreed on by the parties or stipulated in any Convention existing between them. The High Contracting Parties agree that they will carry out 


\section{PROBLEMS IN FOREIGN POLICY}

in full good faith any award that may be rendered. In the event of any failure to carry out the award, the Executive Council shall propose what steps can best be taken to give eff ect thereto.

\section{Article XIV}

The Executive Council shall formulate plans for the establishment of a Permanent Court of International Justice and this Court shall, when established, be competent to hear and determine any matter which the parties recognize as suitable for submission to it for arbitration under the foregoing Article.

\section{Article XV}

If there should arise between States members of the League any dispute likely to lead to a rupture, which is not submitted to arbitration as above, the High Contracting Parties agree that they will refer the matter to the Executive Council; either party to the dispute may give notice of the existence of the dispute to the Secretary-General, who will make all necessary arrangements for a full investigation and consideration thereof. For this purpose the parties agree to communicate to the Secretary-General, as promptly as possible, statements of their case with all the relevant facts and papers, and the Executive Council may forthwith direct the publication thereof.

Where the efforts of the Council lead to the settlement of the dispute, a statement shall be published indicating the nature of the dispute and the terms of 316 


\section{ORIGINAL COVENANT}

settlement, together with such explanations as may be appropriate. If the dispute has not been settled, a report by the Council shall be published, setting forth with all necessary facts and explanations the recommendation which the Council think just and proper for the settlement of the dispute. If the report is unanimously agreed to by the members of the Council other than the parties to the dispute, the High Contracting Parties agree that they will not go to war with any party which complies with the recommendation and that, if any party shall refuse so to comply, the Council shall propose the measures necessary to give effect to the recommendation. If no such unanimous report can be made, it shall be the duty of the majority and the privilege of the minority to issue statements indicating what they believe to be the facts and containing the recommendations which they consider to be just and proper.

The Executive Council may in any case under this Article refer the dispute to the Body of Delegates. The dispute shall be so referred at the request of either party to the dispute, provided that such request must be made within fourteen days after the submission of the dispute. In any case referred to the Body of Delegates all the provisions of this Article and of Article XII relating to the action and powers of the Executive Council shall apply to the action and powers of the Body of Delegates. 


\section{PROBLEMS IN FOREIGN POLICY،}

\section{Article XVI}

Should any of the High Contracting Parties break or disregard its covenants under Article XII, it shall thereby ipso facto be deemed to have committed an act of war against all the other members of the League, which hereby undertake immediately to subject it to the severance of all trade or financial relations, the prohibition of all intercourse between their nationals and the nationals of the covenantbreaking State, and the prevention of all financial, commercial, or personal intercouse between the nationals of the covenant-breaking State and the nationals of any other State, whether a member of the League or not.

It shall be the duty of the Executive Council in such case to recommend what effective military or naval force the members of the League shall severally contribute to the armed forces to be used to protect the covenants of the League.

The High Contracting Parties agree, further, that they will mutually support one another in the financial and economic measures which are taken under this Article, in order to minimize the loss and inconvenience resulting from the above measures, and that they will mutually support one another in resisting any special measures aimed at one of their number by the covenant-breaking State, and that they will afford passage through their territory to the forces of any 318 


\section{ORIGINAL COVENANT}

of the High Contracting Parties who are co-operating to protect the covenants of the League.

\section{Article XVII}

In the event of disputes between one State member of the League and another State which is not a member of the League, or between States not members of the League, the High Contracting Parties agree that the State or States not members of the League shall be invited to accept the obligations of membership in the League for the purposes of such dispute, upon such conditions as the Executive Council may deem just, and upon acceptance of any such invitation, the above provisions shall be applied with such modifications as may be deemed necessary by the League.

Upon such invitation being given the Executive Council shall immediately institute an inquiry into the circumstances and merits of the dispute and recommend such action as may seem best and most effectual in the circumstances.

In the event of a Power so invited refusing to accept the obligations of membership in the League for the purposes of such dispute, and taking any action against a State member of the League which in the case of a State member of the League would constitute a breach of Article $\bar{X} I I$, the provisions of Article XVI shall be applicable as against the State taking such action.

If both parties to the dispute when so invited refuse to accept the obligations of membership in the League 


\section{PROBLEMS IN FOREIGN POLICY}

for the purposes of such dispute, the Executive Council may take such action and make such recommendations as will prevent hostilities and will result in the settlement of the dispute.

\section{Article XVIII}

The High Contracting Parties agree that the League shall be entrusted with the general supervision of the trade in arms and ammunition with the countries in which the control of this traffic is necessary in the common interest.

\section{Article XIX}

To those colonies and territories which as a consequence of the late war have ceased to be under the sovereignty of the States which formerly governed them and which are inhabited by peoples not yet able to stand by themselves under the strenuous conditions of the modern world, there should be applied the principle that the well-being and development of such peoples form a sacred trust of civilization and that securities for the performance of this trust should be embodied in the constitution of the League.

The best method of giving practical effect to this principle is that the tutelage of such peoples should be entrusted to advanced nations who by reason of their resources, their experience or their geographical position, can best undertake this responsibility, and that this tutelage should be exercised by them as mandataries on behalf of the League. 


\section{ORIGINAL COVENANT}

The character of the mandate must differ according to the stage of the development of the people, the geographical situation of the territory, its economic conditions and other similar circumstances.

Certain communities formerly belonging to the Turkish Empire have reached a stage of development where their existence as independent nations can be provisionally recognized subject to the rendering of administrative advice and assistance by a mandatory power until such time as they are able to stand alone. The wishes of these communities must be a principal consideration in the selection of the mandatory power.

Other peoples, especially those of Central Africa, are at such a stage that the mandatary must be responsible for the administration of the territory subject to conditions which will guarantee freedom of conscience or religion, subject only to the maintenance of public order and morals, the prohibition of abuses such as the slave trade, the arms traffic and the liquor traffic, and the prevention of the establishment of fortifications or military and naval bases and of military training of the natives for other than police purposes and the defense of territory, and will also secure equal opportunities for the trade and commerce of other members of the League.

There are territories, such as South-west Africa and certain of the South Pacific Islands, which, owing to the sparseness of their population, or their small size, or their remoteness from the centers of civiliza- 


\section{PROBLEMS IN FOREIGN POLICY}

tion, or their geographical contiguity to the mandatory state, and other circumstances, can be best administered under the laws of the mandatory state as integral portions thereof, subject to the safeguards above-mentioned in the interests of the indigenous population.

In every case of mandate, the mandatory state shall render to the League an annual report in reference to the territory committed to its charge.

The degree of authority, control, or administration to be exercised by the mandatory state shall if not previously agreed upon by the High Contracting Parties in each case be explicitly defined by the Executive Council in a special Act or Charter.

The High Contracting Parties further agree to establish at the seat of the League a Mandatory Commission to receive and examine the annual reports of the Mandatory Powers, and to assist the League in ensuring the observance of the terms of all Mandates.

\section{Article $\mathbf{X X}$}

The High Contracting Parties will endeavor to secure and maintain fair and humane conditions of labor for men, women and children both in their own countries and in all countries to which their commercial and industrial relations extend; and to that end agree to establish as part of the organization of the League a permanent Bureau of Labor. 


\section{ORIGINAL COVENANT}

\section{Article XXI}

The High Contracting Parties agree that provision shall be made through the instrumentality of the League to secure and maintain freedom of transit and equitable treatment for the commerce of all States members of the League, having in mind, among other things, special arrangements with regard to the necessities of the regions devastated during the war of 1914-1918.

\section{Article XXII}

The High Contracting Parties agree to place under the control of the League all international bureaux already established by general treaties if the parties to such treaties consent. Furthermore, they agree that all such international bureaux to be constituted in future shall be placed under the control of the League.

\section{Article XXIII}

The High Contracting Parties agree that every treaty or international engagement entered into hereafter by any State member of the League, shall be forthwith registered with the Secretary-General and as soon as possible published by him, and that no such treaty or international engagement shall be binding until so registered.

\section{Article XXIV}

It shall be the right of the Body of Delegates from time to time to advise the reconsideration by States 323 


\section{PROBLEMS IN FOREIGN POLICY}

members of the League, of treaties which have become inapplicable, and of international conditions, of which the continuance may endanger the peace of the world.

\section{Article XXV}

The High Contracting Parties severally agree that the present Covenant is accepted as abrogating all obligations inter se which are inconsistent with the terms thereof, and solemnly engage that they will not hereafter enter into any engagements inconsistent with the terms thereof.

In case any of the Powers signatory hereto or subsequently admitted to the League shall, before becoming a party to this Covenant, have undertaken any obligations which are inconsistent with the terms of this Covenant, it shall be the duty of such Power to take immediate steps to procure its release from such obligations.

\section{Article XXVI}

Amendments to this Covenant will take effect when ratified by the States whose representatives compose the Executive Council and by three-fourths of the States whose representatives compose the Body of Delegates. 


\section{THE SENATE "ROUND ROB- IN" AGAINST THE LEAGUE OF NATIONS}

Whereas, under the Constitution, it is a function of the Senate to advise and consent to, or dissent from the ratification of any treaty of the United States, and no such treaty can become operative without the consent of the Senate expressed by the affirmative vote of two-thirds of the Senators present, and

Whereas, owing to the victory of the arms of the United States and of the nations with whom it is associated, a Peace Conference was convened, and is now in session at Paris for the purpose of settling the terms of peace; and,

Whereas, a Committee of the conference has proposed a constitution for a League of Nations, and the proposal is now before the Peace Conference for its consideration;

Now, therefore, be it resolved, by the Senate of the United States in the discharge of its constitutional duty of advice in regard to treaties, that it is the sense of the Senate that, while it is the sincere desire that the nations of the world should unite to promote peace and general disarmament the Constitution of the League of Nations in the form now proposed to 325 


\section{PROBLEMS IN FOREIGN POLICY}

the Peace Conference should not be accepted by the United States.

And be it resolved further, that it is the sense of the Senate that the negotiations on the part of the United States should immediately be directed to the utmost expedition of the urgent business of negotiating peace terms with Germany satisfactory to the United States and the nations with whom the United States is associated in the war against the German Government, and the proposal for a League of $\mathrm{Na-}$ tions to insure the permanent peace of the world should be then taken up for careful and serious consideration.

(Signed) Henry Cabot Lodge, of Massachusetts, and thirty-eight other Senators and Senatorselect, as follows:

California, JoH nsoN

Colorado, Phipps

Connecticut, Brandeger and McLea

Delaware, BALI

Idaho, BoraH

Illinois, Sherman and McCoRMICk

Indiana, New and WAtsoN

Iowa, Cummins

Kansas, Curtis

Maine, Hale and Fervald

Maryland, France

Michigan, Tow NSEND and NEWBERRY

Missouri, Spencer

New Hampshire, Moses and KEYES
New Jersey, Frelinghuysen and Evge

New Mexico, F A.LL

New York, W ADsworth and Calder

North Dakota, Growna

Ohio, Harding

Pennsylvania, $\mathrm{K}_{\text {vox }}$ and Penrose

South Dakota, Sterling

Utah, Smoor

Vermont, Dillingham and PAGE

Washington, Poindexter

West Virginia, Sutherland and Elkins

Wisconsin, LeNroOT

Wyoming, W ARREN 


\section{AMENDMENTS PROPOSED TO THE ORIGINAL DRAFT OF THE CONSTITUTION OF THE LEAGUE OF NATIONS}

By the Honorable William Howard Taft

First.-An amendment making reservations designed to safeguard the Monroe Doctrine and to satisfy those Senators and others who fear the Monroe Doctrine might be jeopardized by the League of $\mathrm{Na}$ tions, this amendment being drafted so that agreements under the League covenant shall not be construed as an infringement upon the principles of international policies heretofore generally recognized.

Second.-An amendment definitely affirming the right of any country in the League to control matters solely within its domestic jurisdiction, this reservation being broad enough to protect the United States in dealing with immigration and preventing the influx of foreign labor.

Third.-An amendment definitely stating the rule of unanimity and making it perfectly plain that any action taken by the Executive Council of the League must be unanimous, thereby necessitating the concurrence of the American Government's member of 327 


\section{PROBLEMS IN FOREIGN POLICY}

the Executive Council before its action could be binding on the United States.

Fourth.-An amendment by way of definite statement on the right of nations to withdraw from the League of Nations and possibly providing for a definite term, perhaps ten years, for the League as a whole, and a definite term for the obligation to restrict armament within such limit as may be agreed upon.

\section{By the Honorable Charles Evans Hughes}

Having explained at the outset that he would not attempt to review matters of mere form, as it seemed to be conceded that the covenant was poorly drafted, and its most earnest supporters had severely criticized it, Mr. Hughes said he thought the Covenant should be amended as follows:

"(1) By explicit provision as to the requirement of unanimity in decision.

"(2) By suitable limitation as to the field of the league's inquiries and action, so as to leave no doubt that the internal concerns of States, such as immigration and tariff laws, are not embraced.

"(3) By providing that no foreign Power shall hereafter acquire, by consent, purchase or in any other way any possession on the American Continent or the islands adjacent thereto.

“(4) By providing that the settlement of purely American questions shall be remitted primarily to the 328 


\section{PROPOSED AMENDMENTS}

American nations, and that European nations shall not intervene unless requested to do so by the American nations.

“(5) By omitting the guaranty of Article $\mathrm{X}$ [which pledges the nations in the compact to undertake to preserve against external aggression the territorial integrity and existing political independence of every State in the league.]

"(6) By providing that no member of the league shall be constituted a mandatary without its consent, and no European or Asiatic Power shall be constituted a mandatary of any American people.

"(7) By providing that any member of the league may withdraw at its pleasure on specified notice."

Mr. Hughes criticized severely the tenth article of the covenant, under which the "High Contracting Parties" undertake to "respect and preserve as against external aggression the territorial integrity and existing political independence of all states members of the league." Conceding the argument that this clause had been included to protect the nations born of the war, the speaker regarded it "as a trouble-breeder and not a peace maker."

It makes no allowance, he said, for changes in the make-up of member nations which may be found advisable and "ascribes a soundness of judgment to the peace conference in erecting States and defining boundaries which nobody in the history of the world has ever possessed." 


\section{PROBLEMS IN FOREIGN POLICY}

Mr. Hughes said definite recognition should be made in the league covenant of the Monroe Doctrine and, while urging a clause prohibiting European aggression on the American continent in any form, he advocated also reserving the right of any nation to decline a mandatary for the administration of foreign territory.

\section{By the Honorable Elihu Root}

\section{First Amendment}

Strike out Article XIII, and insert the following:-

The High Contracting Powers agree to refer to the existing Permanent Court of Arbitration at The Hague, or to the Court of Arbitral Justice proposed at the Second Hague Conference when established, or to some other Arbitral Tribunal, all disputes between them (including those affecting honor and vital interests) which are of a justiciable character, and which the powers concerned have failed to settle by diplomatic methods. The powers so referring to arbitration agree to accept and give effect to the award of the Tribunal.

Disputes of a justiciable character are defined as disputes as to the interpretation of a treaty, as to any question of international law, as to the existence of any fact which if established would constitute a breach of any international obligation, or 


\section{PROPOSED AMENDMENTS}

as to the nature and extent of the reparation to be made for any such breach.

Any question which may arise as to whether a dispute is of a justiciable character is to be referred for decision to the Court of Arbitral Justice when constituted, or, until it is constituted, to the existing Permanent Court of Arbitration at The Hague.

\section{Second Amendment}

Add to Article XIV the following paragraph:-

"The Executive Council shall call a general conference of the Powers to meet not less than two years or more than five years after the signing of this convention for the purpose of reviewing the condition of International Law, and of agreeing upon and stating in authoritative form the principles and rules thereof.

"Thereafter regular conferences for that purpose shall be called and held at stated times."

\section{Third Amendment}

Immediately before the signature of the American delegates, insert the following reservation:

"Inasmuch as in becoming a member of the League the United States of America is moved by no interest or wish to intrude upon or interfere with the political policy or internal administration of any foreign State, and by no existing or anticipated dangers in the affairs of the American continents, but accedes to the wish of the European States that it shall join its power to theirs for the preservation of general peace, 


\section{PROBLEMS IN FOREIGN POLICY}

the representatives of the United States of America sign this convention with the understanding that nothing therein contained shall be construed to imply a relinquishment by the United States of America of its traditional attitude towards purely American questions, or to require the submission of its policy regarding such questions, (including therein the admission of immigrants,) to the decision or recommendation of other powers."

\section{Fourth Amendment}

Add to Article $\mathrm{X}$ the following:

"After the expiration of five years from the signing of this convention any party may terminate its obligation under this Article by giving one year's notice in writing to the Secretary General of the League."

\section{Fifth Amendment}

Add to Article IX the following:

"Such Commission shall have full power of inspection and verification personally and by authorized agents as to all armament, equipment, munitions, and industries referred to in Article VIII."

\section{Sixth Amendment}

Add to Article XXIV the following:

"The Executive Council shall call a general conference of members of the League to meet not less than five or more than ten years after the signing 332 


\section{PROPOSED AMENDMENTS}

of this convention for the revision thereof, and at that time, or at any time thereafter upon one year's notice, any member may withdraw from the League."

Reservation Made to the Hague Conventions of 1899 ANd 1907 Regarding the Monroe

Doctrine

"Nothing contained in this Convention shall be so construed as to require the United States of America to depart from its traditional policy of not intruding upon, interfering with, or entangling itself in the political questions or policy or internal administration of any foreign State; nor shall anything contained in the said Convention be construed to imply a relinquishment by the United States of America of its traditional attitude toward purely American questions." 


\section{THE COVENANT AS REVISED}

The following is the text of the Covenant of the League of Nations as adopted by the plenary session of the Peace Conference on April 28, 1919:

\section{THE COVENANT OF THE LEAGUE OF NATIONS 1}

In order to promote international coöperation and to achieve international peace and security, by the acceptance of obligations not to resort to war, by the prescription of open, just and honorable relations between nations, by the firm establishment of the understandings of international law as to actual rule of conduct among Governments, and by the maintenance of justice and a scrupulous respect for all treaty obligations in the dealings of organized peoples with one another, the high contracting parties agree to this covenant of the League of Nations.

\section{Article I}

The original members of the League of Nations shall be those of the signatories which are named in the annex to this covenant and also such of those

${ }^{1}$ The text is a reproduction of that issued by the Department of State at Washington.

334 


\section{COVENANT AS REVISED}

other states named in the annex as shall accede without reservation to this covenant. Such accessions shall be effected by a declaration deposited with the Secretariat within two months of the coming into force of the covenant. Notice thereof shall be sent to all other members of the League.

Any fully self-governing state, dominion or colony not named in the annex, may become a member of the League if its admission is agreed by two-thirds of the assembly, provided that it shall give effective guarantees of its sincere intention to observe its international obligations, and shall accept such regulations as may be prescribed by the League in regard to its military and naval forces and armaments.

Any member of the League, may, after two years' notice of its intention so to do, withdraw from the League, provided that all its international obligations and all its obligations under this covenant shall have been fulfilled at the time of its withdrawal.

\section{Article II}

The action of the League under this covenant shall be effected through the instrumentality of an Assembly and of a Council, with a permanent Secretariat.

\section{Article III}

The Assembly shall consist of representatives of the members of the League.

The Assembly shall meet at stated intervals and 335 


\section{PROBLEMS IN FOREIGN POLICY}

from time to time as occasion may require, at the seat of the League, or at such other place as may be decided upon.

The Assembly may deal at its meetings with any matter within the sphere of action of the League or affecting the peace of the world.

At meetings of the Assembly, each member of the League shall have one vote, and may have not more than three representatives.

\section{Article IV}

The Council shall consist of representatives of the United States of America, of the British Empire, of France, of Italy, and of Japan, together with representatives of four other members of the League. These four members of the League shall be selected by the Assembly from time to time in its discretion. Until the appointment of the representatives of the four members of the League first selected by the Assembly, representatives of (blank) shall be members of the Council.

With the approval of the majority of the Assembly, the Council may name additional members of the League whose representatives shall always be members of the Council; the Council with like approval may increase the number of members of the League to be selected by the Assembly for representation on the Council.

The Council shall meet from time to time as occasion may require, and at least once a year, at the 336 


\section{COVENANT AS REVISED}

seat of the League, or at such other place as may be decided upon.

The Council may deal at its meetings with any matter within the sphere of action of the League or affecting the peace of the world.

Any member of the League not represented on the Council shall be invited to send a representative to sit as a member at any meeting of the Council during the consideration of matters specially affecting the interests of that member of the League.

At meetings of the Council, each member of the League represented on the Council shall have one vote, and may have not more than one representative.

\section{Article V}

Except where otherwise expressly provided in this covenant, or by the terms of the treaty, decisions at any meeting of the Assembly or of the Council shall require the agreement of all the members of the League represented at the meeting.

All matters of procedure at meetings of the Assembly or of the Council, the appointment of committees to investigate particular matters, shall be regulated by the Assembly or by the Council and may be decided by a majority of the members of the League represented at the meeting.

The first meeting of the Assembly and the first meeting at the Council shall be summoned by the President of the United States of America. 


\section{PROBLEMS IN FOREIGN POLICY}

\section{Article VI}

The permanent Secretariat shall be established at the seat of the League. The Secretariat shall comprise a Secretariat General and such secretaries and staff as may be required.

The first Secretary General shall be the person named in the annex; thereafter the Secretary General shall be appointed by the Council with the approval of the majority of the Assembly.

The Secretaries and the staff of the Secretariat shall be appointed by the Secretary General with the approval of the Council.

The Secretary General shall act in that capacity at all meetings of the Assembly and of the Council.

The expenses of the Secretariat shall be borne by the members of the League in accordance with the apportionment of the expenses of the International Bureau of the Universal Postal Union.

\section{Article VII}

The seat of the League is established at Geneva.

The Council may at any time decide that the seat of the League shall be established elsewhere.

All positions under or in connection with the League, including the Secretariat, shall be open equally to men and women.

Representatives of the members of the League and officials of the League when engaged on the business of the League shall enjoy diplomatic privileges and immunities. 


\section{COVENANT AS REVISED}

The buildings and other property occupied by the League or its officials or by representatives attending its meetings shall be inviolable.

\section{Article VIII}

The members of the League recognize that the maintenance of a peace requires the reduction of national armaments to the lowest point consistent with national safety and the enforcement by common action of international obligations.

The Council, taking account of the geographical situation and circumstances of each state, shall formulate plans for such reduction for the consideration and action of the several governments.

Such plans shall be subject to reconsideration and revision at least every ten years.

After these plans shall have been adopted by the several governments, limits of armaments therein fixed shall not be exceeded without the concurrence of the Council.

The members of the League agree that the manufacture by private enterprise of munitions and implements of war is open to grave objections. The Council shall advise how the evil effects attendant upon such manufacture can be prevented, due regard being had to the necessities of those members of the League which are not able to manufacture the munitions and implements of war necessary for their safety.

The members of the League undertake to inter339 


\section{PROBLEMS IN FOREIGN POLICY}

change full and frank information as to the scale of their armaments, their military and naval programmes and the condition of such of their industries as are adaptable to warlike purposes.

\section{Article IX}

A permanent commission shall be constituted to advise the Council on the execution of the provisions of Articles I and VIII and on military and naval questions generally.

\section{Article $\mathbf{X}$}

The members of the League undertake to respect and preserve as against external aggression the territorial integrity and existing political independence of all members of the League. In case of any such aggression or in case of any threat or danger of such aggression, the Council shall advise upon the means by which this obligation shall be fulfilled.

\section{Article XI}

Any war or threat of war whether immediately affecting any of the members of the League or not, is hereby declared a matter of concern to the whole League, and the League shall take any action that may be deemed wise and effectual to safeguard the peace of nations. In case any such emergency should arise, the Secretary-General shall, on the request of any member of the League, forthwith summon a meeting of the Council.

It is also declared to be the fundamental right of 340 


\section{COVENANT AS REVISED}

each member of the League to bring to the attention of the Assembly or of the Council any circumstance whatever affecting international relations which threatens to disturb either the peace or the good understanding between nations upon which peace depends.

\section{Article XII}

The members of the League agree that if there should arise between them any dispute likely to lead to a rupture, they will submit the matter either to arbitration or to inquiry by the Council, and they agree in no case to resort to war until three months after the award by the arbitrators or the report by the Council.

In any case under this Article the award of the arbitrators shall be made within a rcasonable time, and the report of the Council shall be made within six months after the submission of the dispute.

\section{Article XIII}

The members of the League agree that whenever any dispute shall arise between them which they recognize to be suitable for submission to arbitration and which cannot be satisfactorily settled by diplomacy, they will submit the whole subject matter to arbitration. Disputes as to the interpretation of a treaty, as to any question of international law, as to the existence of any fact which if established would constitute a breach of any international obligation, or as to the extent and nature of the reparation to be 341 


\section{PROBLEMS IN FOREIGN POLICY}

made for any such breach, are declared to be among those which are generally suitable for submission to arbitration. For the consideration of any such dispute the court of arbitration to which the case is referred shall be the court agreed on by the parties to the dispute or stipulated in any convention existing between them.

The members of the League agree that they will carry out in full good faith any award that may be rendered and that they will not resort to war against a member of the League which complies therewith. In the event of any failure to carry out such an award, the Council shall propose what steps should be taken to give effect thereto.

\section{Article XIV}

The Council shall formulate and submit to the members of the League for adoption plans for the establishment of a permanent court of international justice. The court shall be competent to hear and determine any dispute of an international character which the parties thereto submit to it. The court may also give an advisory opinion upon any dispute or question referred to it by the Council or by the Assembly.

\section{Article XV}

If there should arise between members of the League any dispute likely to lead to a rupture, which is not submitted to arbitration as above, the members of the League agree that they will submit the matter 342 


\section{COVENANT AS REVISED}

to the Council. Any party to the dispute may effect such submission by giving notice of the existence of the dispute to the Secretary-General, who will make all necessary arrangements for a full investigation and consideration thereof. For this purpose the parties to the dispute will communicate to the Secretary-General, as promptly as possible, statements of their case, all the relevant facts and papers; the Council may forthwith direct the publication thereof.

The Council shall endeavor to effect a settlement of , any dispute, and if such efforts are successful, a state'ment shall be made public giving such facts and explanations regarding the dispute, terms of settlement thereof as the Council may deem appropriate.

If the dispute is not thus settled, the Council either unanimously or by a majority vote shall make and publish a report containing a statement of the facts of the dispute and the recommendations which are deemed just and proper in regard thereto.

Any member of the League represented on the Council may make public a statement of the facts of the dispute and of its conclusions regarding the same.

If a report by the Council is unanimously agreed to by the members thereof other than the representatives of one or more of the parties to the dispute, the members of the League agree that they will not go to war with any party to the dispute which complies with the recommendations of the report.

If the Council fails to reach a report which is 343 


\section{PROBLEMS IN FOREIGN POLICY}

unanimously agreed to by the members thereof, other than the representatives of one or more of the parties to the dispute, the members of the League reserve to themselves the right to take such action as they shall consider necessary for the maintenance of right and justice.

If the dispute between the parties is claimed by one of them, and is found by the Council, to arise out of a matter which by international law is solely within the domestic jurisdiction of that party, the Council shall so report, and shall make no recommendation as to its settlement.

The Council may in any case under this Article refer the dispute to the Assembly. The dispute shall be so referred at the request of either party to the dispute, provided that such request be made within fourteen days after the submission of the dispute to the Council.

In any case referred to the Assembly all the provisions of this Article and of Article XII relating to the action and powers of the Council shall apply to the action and powers of the Assembly, provided that a report made by the Assembly, if concurred in by the representatives of those members of the League represented on the Council and of a majority of the other members of the League, exclusive in each case of the representatives of the parties to the dispute, shall have the same force as a report by the Council concurred in by all the members thereof other than 


\section{COVENANT AS REVISED}

the representatives of one or more of the parties to the dispute.

\section{Article XVI}

Should any member of the League resort to war in disregard of its covenants under Articles XII, XIII or $\mathrm{XV}$, it shall ipso facto be deemed to have committed an act of war against all other members of the League, which hereby undertake immediately to subject it to the severance of all trade or financial relations, the prohibition of all intercourse between their nationals and the nationals of the covenantbreaking state and the prevention of all financial, commercial, or personal intercourse between the nationals of the covenant-breaking state and the nationals of any other state, whether a member of the League or not.

It shall be the duty of the Council in such case to recommend to the several governments concerned what effective military or naval forces the members of the League shall severally contribute to the armaments of forces to be used to protect the covenants of the League.

The members of the League agree, further, that they will mutually support one another in the financial and economic measures which are taken under this Article, in order to minimize the loss and inconvenience resulting from the above measures, and that they will mutually support one another in resisting any special measures aimed at one of their number 


\section{PROBLEMS IN FOREIGN POLICY}

by the covenant-breaking state, and that they will take the necessary steps to afford passage through their territory to the forces of any of the members of the League which are co-operating to protect the covenants of the League.

Any member of the League which has violated any covenant of the League may be declared to be no longer a member of the League by a vote of the Council concurred in by the representatives of all the other members of the League represented thereon.

\section{Article XVII}

In the event'of a dispute between a member of the League and a state which is not a member of the League, or between states not members of the League, the state or states not members of the League shall be invited to accept the obligations of membership in the League for the purposes of such dispute, upon such conditions as the Council may deem just. If such invitation is accepted, the provisions of Articles XII to XVI inclusive shall be applied with such modifications as may be deemed necessary by the Council.

Upon such invitation being given, the Council shall immediately institute an inquiry into the circumstances of the dispute and recommend such action as may seem best and most effectual in the circumstances.

If a state so invited shall refuse to accept the obligations of membership in the League for the purposes of such dispute, and shall resort to war against 346 


\section{COVENANT AS REVISED}

a member of the League, the provisions of Article $\mathrm{XVI}$ shall be applicable as against the state taking such action.

If both parties to the dispute, when so invited refuse to accept the obligations of membership in the League for the purposes of such dispute, the Council may take such measures and make such recommendations as will prevent hostilities and will result in the settlement of the dispute.

\section{Article XVIII}

Every convention or international engagement entered into henceforward by any member of the League, shall be forthwith registered with the Secretariat and shall as soon as possible be published by it. No such treaty or international engagement shall be binding until so registered.

\section{Article XIX}

The Assembly may from time to time advise the reconsideration by members of the League of treaties which have become inapplicable, and the consideration of international conditions whose continuance might endanger the peace of the world.

\section{Article $\mathbf{X X}$}

The members of the League severally agree that this covenant is accepted as abrogating all obligations or understandings inter se which are inconsistent with the terms thereof, and solemnly undertake that 


\section{PROBLEMS IN FOREIGN POLICY}

they will not hereafter enter into any engagements inconsistent with the terms thereof.

In case members of the League shall, before becoming a member of the League, have undertaken any obligations inconsistent with the terms of this covenant, it shall be the duty of such member to take immediate steps to procure its release from such obligations.

\section{Article XXI}

Nothing in this covenant shall be deemed to affect the validity of international engagements such as treaties of arbitration or regional understandings like the Monroe Doctrine for securing the maintenance of peace.

\section{Article XXII}

To those colonies and territories which as a consequence of the late war have ceased to be under the sovereignty of the states which formerly governed them and which are inhabited by peoples not yet able to stand by themselves under the strenuous conditions of the modern world, there should be applied the principle that the well-being and development of such peoples form a sacred trust of civilization and that securities for the performance of this trust should be embodied in this covenant.

The best method of giving practicable eff ect to this principle is that the tutelage of such peoples be entrusted to advanced nations who, by reasons of their resources, their experience or their geographical posi- 


\section{COVENANT AS REVISED}

tion, can best undertake this responsibility, and who are willing to accept it, and that this tutelage should be exercised by them as mandatories on behalf of the League.

The character of the mandate must differ according to the stage of the development of the people, the geographical situation of the territory, its economic condition and other similar circumstances.

Certain communities formerly belonging to the Turkish Empire have reached a stage of development where their existence as independent nations can be provisionally recognized subject to the rendering of administrative advice and assistance by a mandatory until such time as they are able to stand alone. The wishes of these communities must be a principal consideration in the selection of the mandatory.

Other peoples, especially those of Central Africa, are at such a stage that the mandatory must be responsible for the administration of the territory under conditions which will guarantee freedom of conscience or religion subject only to the maintenance of public order and morals, the prohibition of abuses such as the slave trade, the arms traffic and the liquor traffic and the prevention of the establishment of fortifications or military and naval bases and of military training of the natives for other than police purposes and the defense of territory and will also secure equal opportunities for the trade and commerce of other members of the League. 


\section{PROBLEMS IN FOREIGN POLICY}

There are territories, such as Southwest Africa and certain of the South Pacific islands, which, owing to the sparseness of their population or their small size or their remoteness from the centers of civilization or their geographical contiguity to the territory of the mandatory and other circumstances, can be best administered under the laws of the mandatory as integral portions of its territory subject to the safeguards above mentioned in the interests of the indigenous population. In every case of mandate, the mandatory shall render to the Council an annual report in reference to the territory committed to its charge.

The degree of authority, control or administration to be exercised by the mandatory shall, if not previously agreed upon by the members of the League, be explicitly defined in each case by the Council.

A permanent commission shall be constituted to receive and examine the annual reports of the mandatories and to advise the Council on all matters relating to the observance of the mandates.

\section{Article XXIII}

Subject to and in accordance with the provisions of international conventions existing or hereafter to be agreed upon, the members of the League (a) will endeavor to secure and maintain fair and humane conditions of labor for men, women and children both in their own countries and in all countries to which their commercial and industrial relations extend, and 


\section{COVENANT AS REVISED}

for that purpose will establish and maintain the necessary international organizations; (b) undertake to secure just treatment of the native inhabitants of territories under their control; (c) will entrust the League with the general supervision over the execution of agreements with regard to the traffic in women and children, and the traffic in opium and other dangerous drugs; (d) will entrust the League with the general supervision of the trade in arms and ammunition with the countries in which the control of this traffic is necessary in the common interest; (e) will make provision to secure and maintain freedom of communication and of transit and equitable treatment for the commerce of all members of the League. In this connection the special necessities of the regions devastated during the war of 1914-1918 shall be in mind; (f) will endeavor to take steps in matters of international concern for the prevention and control of disease.

\section{Article XXIV}

There shall be placed under the direction of the League all international bureaus already established by general treaties if the parties to such treaties consent. All such international bureaus and all commissions for the regulation of matters of international interest hereafter constituted shall be placed under the direction of the League.

In all matters of international interest which are 351 


\section{PROBLEMS IN FOREIGN POLICY}

regulated by general conventions but which are not placed under the control of international bureaus or commissions, the Secretariat of the League shall, subject to the consent of the Council and if desired by the parties, collect and distribute all relevant information and shall render any other assistance which may be necessary or desirable.

The Council may include as part of the expenses of the Secretariat the expenses of any burean or commission which is placed under the direction of the League.

\section{Article XXV}

The members of the League agree to encourage and promote the establishment and co-operation of duly authorized voluntary national Red Cross organizations having as purposes improvement of health, the prevention of disease and the mitigation of suffering throughout the world.

\section{Article XXVI}

Amendments to this covenant will take effect when ratified by the members of the League whose representatives compose the Council and by a majority of the members of the League whose representatives compose the Assembly.

No such amendment shall bind any member of the League which signifies its dissent therefrom, but in that case it shall cease to be a member of the League. 


\section{COVENANT AS REVISED}

Annex to the Covenant

One. Original members of the League of $\mathrm{Na}$ tions.

Signatories of the Treaty of Peace.

United States of America, Belgium, Bolivia, Brazil, British Empire, Canada, Australia, South Africa, New Zealand, India, China, Cuba, Czecho-Slovakia, Ecuador, France, Greece, Guatemala, Haiti, Hedjaz, Honduras, Italy, Japan, Liberia, Nicaragua, Panama, Peru, Poland, Portugal, Roumania, Servia, Siam, Uruguay.

States invited to accede to the covenant:

Argentine Republic, Chile, Colombia, Denmark, Netherlands, Norway, Paraguay, Persia, Salvador, Spain, Sweden, Switzerland, Venezuela.

Two. First Secretary General of the League of nations. ${ }^{2}$

${ }^{2}$ The appointment of Sir James Eric Drummond, of the British Foreign Office, as Secretary General is announced. 



\section{INDEX}

Adams, John, 77

"Amalfi, table of," 99

Amendments, 276, 283, 327-333

American republics, 146 Arbitration, as provided for in the Covenant, 120-121

Armenia, 137

Asquith, Mr., 8

Austin, John, 82

Authority of the Covenant under the

Constitution of the United States, 149, 155-157

Balance of Power, 15, 16, 212, 213, 245

Balfour, Mr., 8, 10

Bernstorff, Count von, 39 Blackstone, Sir William, 70
Bolshevism, 49, 137, 201, 223, 232, 249, 250, 251,262

Bonaparte, Napoleon I, 254

Bourgeois, Monsieur, 10, 204, 205

British Prize Cqurt, 7172, 73-75

Brockdorff - R a n tz a u,

Count von, 39

Brotherhood of Men, 33 Burlamaqui, 77

Butler, Charles Henry, 172

Calmoun, John C., 167168

Cambon, Paul, 101

Cartography, peace by, 256,257

Castlereagh, Lord, 241, 242 


\section{INDEX}

Cecil, Lord Robert, 276 Challenge, the President's, to the Senate, 264,265

Clayton-Bulwer treaty: the, 107-108

Clemenceau, Monsieur, 204, 205, 211, 212, 298

Cleveland, President, 134 Conscription, 13, 14 "Consolato," the, 99

Constitution of the League of Nations.

See Covenant

Cooper, Sir R., 151

Council. See Executive

Council and Supreme Council

Covenant, the, as agreed upon at Paris, on February 14, 1919, 309

as revised, 334 attitude of, toward International Law, 122

not merely an agreement, 110, 111
Covenant, the, work of politicians, not of jurists, 120

Crandall, 172

Crucé, Emeric, 1

Cuba, 127, 243

Curzon, Lord, 10, 11

Declaration of Rights, 22

Democracy, character of the German, 52, 53 tendency of, to oligarchy, 12, 13

Denmark, 130, 131

Devlin, 172, 173

Direct taxes, 156

Distribution of power, $158,159,160,161$

Dumas, 78

Ebert, Premier of Germany, 52, 54

Edward VII, 188

Efficiency, A m e ric a n, cause of, 32

Entente of Free Nations, character of, the, 34, $35,76,117,118$, 


\section{INDEX}

119, 174, 195, 222, Full powers, British for223, 225

Entente of Free Nations, formula of, 101 referred to, 227, 261, 262

"Eternal Peace," 3

Executive Council, powers of the, 114-119, 123-125, 274-282, 293

Expediency, not considered, 219, 283

Farrand, Max, 86 Federation, 24, 94, 144145

Firth, J. B., 9, 11

Fiscal policy, 31

Foreign policy, independence in, 25

"Fourteen Points" of

President Wilson, 180, 181, 206, 259, 260,303

Franklin, Benjamin, 79 Freedom of the seas, 98, 128, 209, 210 "Free Nations," 26 mula of, 140

George, Lloyd, 8, 152 Gray, Mr. Justice, 74 "Great Design," the, 2 Grey, Sir Edward, now Viscount, 100-101 Grotius, Hugo, 1, 4, 76, 77

Hague Conferences, the, 90

Hague Conventions, the, 121

Hamilton, Alexander, 71, $77,87,88,185$

Hapsburg, House of, 2 Harden, Maximilian, 65 Harrison, Austin, 14-21 Henry IV, of France, 1, 208

Hindenburg, Field-Marshal von, 51,54 Hohenzollern dynasty, 42. See also William II

Holy Alliance, 240-242, 253 


\section{INDEX}

Hughes, Charles Evans, 284-288, 328-330

IMPERIALISM，138，139; 147,176

Imperium, the, of the League of Nations, $111,112,113,126$, 131，132，134，148, $174,175,178,252$

Indemnities, 61, 62, 65 Industries, Belgian, 59, 61

French, 59, 61

German, 56, 57, 58, 60 Inequality of nations, 27 , 31

International government, 23, 24, 25, 29, 30

International Law, as affected by treaties, 89,90

authority of, 91, 92 attitude of the Covenant toward, 122, $123,127,128$, 128

born of the sea, 99
International Law, character of, 75-76, 8384

conditions of establishing, 22

part of Common Law, 70-71

part of United States law, 74-75, 91 revision of, 289,290 violations of, 16

JAY, John, 84

Jefferson, President, 175 Johnson, Willis Fletcher, 135-136

Jugemens d'Oléron, 99

Juristic equality of nations, 27

KANT, Immanuel, 3, 24 Knox, Senator, 274-282

LABor, Bureau of, 255

Lapradelle, Professor de, 79

Law, Bonar, 151-153

Law of Nations. See International Law 


\section{INDEX}

Laws of Wisby, 99

League of Nations, the, as an American idea, $15,16,21,299$

a corporate entity, 108110

criticism of, not partisan, 283

not spontaneously assented to, 204

not ultimate ideal, 259 , 288

schemes of, 17, 23, 24

sovereign character of, 133

League to Enforce Peace, $20,25,205,273$

Liberum veto, 116

London, secret treaty of, 287

Louisiana Purchase, 175

Madison, James, 166167

"Manchester Guardian," 137

Manchester, President's speech at, 211
Mandataries, 112, 135138, 174-176, 214, 288, 298

National Conferences, 22

National interests, 231232

Nationalism, necessity of, 249

Neutrality, 14, 97-98, 128-131, 174, 210, 298

Norway, 130-131

Oligarchy in DemocRACX, 12-15

Orders in Council, 71-73

Pan-Germanism, 257

Paquete Habana, case of the, 74

Parker, Lord, 72, 97

Peace, terms of, 63, 64 Persia, 137

President of the United States. See Treatymaking power, also Wilson 


\section{INDEX}

"Project of Perpetual Peace," 8, 237-239

Pufendorf, 77

Reparation, 61-62, 65 Roman Law, 77

Root, Elihu, 120-121, 159-160, 284, 288290, 330-333

Samoan Islands, 96, 134-136, 176

Self-determination, 27 , $28,248,249,255$

Senate, the constitutional relation of the, to the treaty-making power, 267-272. See also Treaty-making power

Senate "Round Robin," the, 325

Siberia, 12

Siéyès, 9

Simonds, Frank H., 202 Smith, Sir Frederick, 71 Smuts, General, 138, 176-178, 213, 297, 300
Society of States, nature of the, 259-260, 289 Sovereignty, 24, 138, 275

Standard of living, 3132

State, the, as an economic entity, 28-31

Stafford, Mr. Justice, 109 St. Pierre, the Abbé de, 3 , 237-239

Sully, Duke of, 1, 208 Super-government, the League of Nations a, 112-118, 173-174, 223-225, 226, 272$276,280,281$

Supreme Council, 254, 258,296

Sweden, 130-131

Switzerland, 129-130

Sydenham, Lord, 9

TAFT, Henry W., 124 Taft, William Howard, 273-283, 327-328

Thirty Years' War, 1 Treaties, as contracts, 106-108 


\section{INDEX}

Treaties, not abrogated by unilateral legislation, 106, 108 the supreme law of the land, 80, 81 under the Confederation, 84

when self-executing, 86 Treaty-making power, under the Constitution of the United States, 149-150, 155, 170-171

limitations of the, 157169

under the British Government, 150-156

Tucker, John Randolph, 168-169

Tucker, St. George, the elder, 168

UnANIMITy, in the Executive Council of the League of $\mathrm{Na}$ tions, 275-277

Utrecht, Congress of, 3 , 237

VATTEL, 77-78

WAR DEBTS, 65-66

Washington, President, 84, 242

Westphalia, Congress of, 1

William II, German Emperor, 42-48, 183

Wilson, President, 6-7, 18-19, 38-40, 61-64, $137,180-185,202$, 211 , 218-220, 233235, 263-264, 282, 294

Workmen and Soldiers, Councils of, 49

Zamora, case of the, 72 


THIS BOOK IS DUE ON THE LAST DATE STAMPED BELOW

\section{AN INITIAL FINE OF 25 CENTS}

WILL BE ASSESSED FOR FAILURE TO RETURN THIS BOOK ON THE DATE DUE. THE PENALTY WILL INCREASE TO 50 CENTS ON THE FOURTH DAY AND TO \$1.00 ON THE SEVENTH DAY OVERDUE.

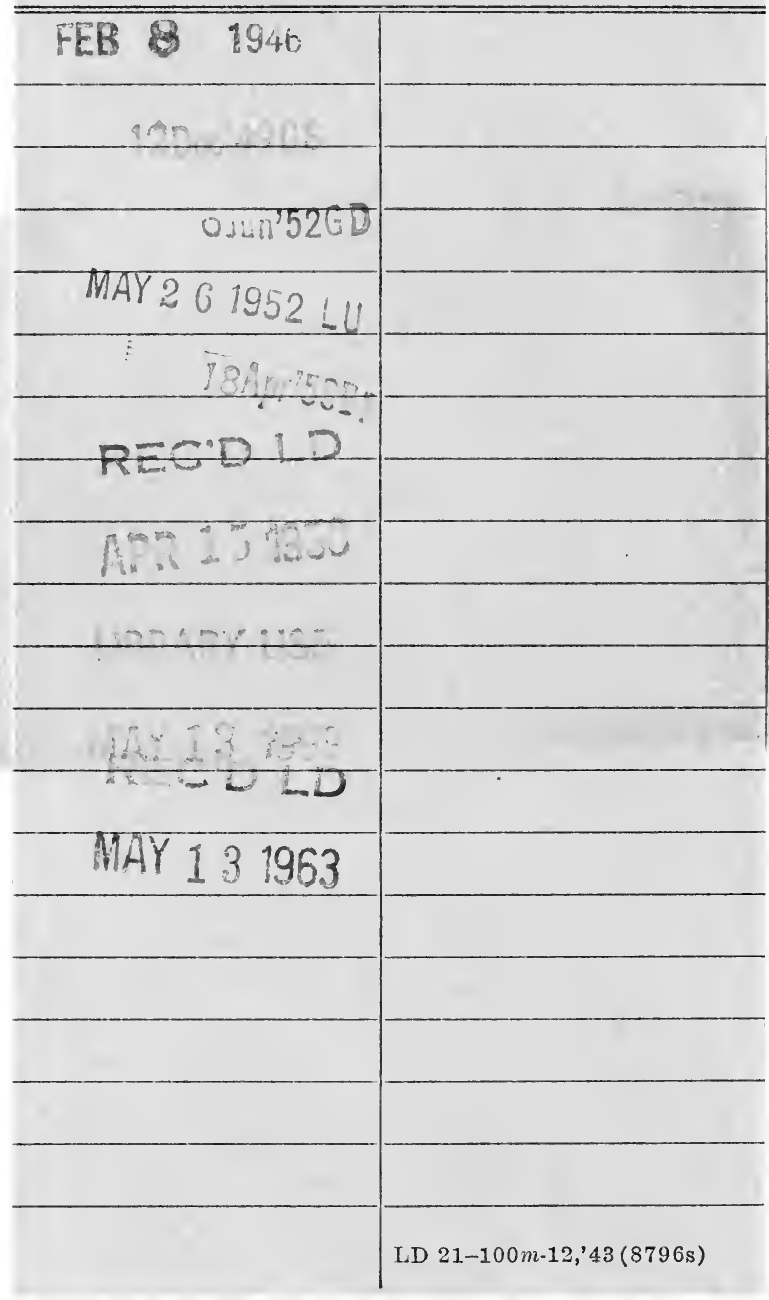




\section{YE 06280}

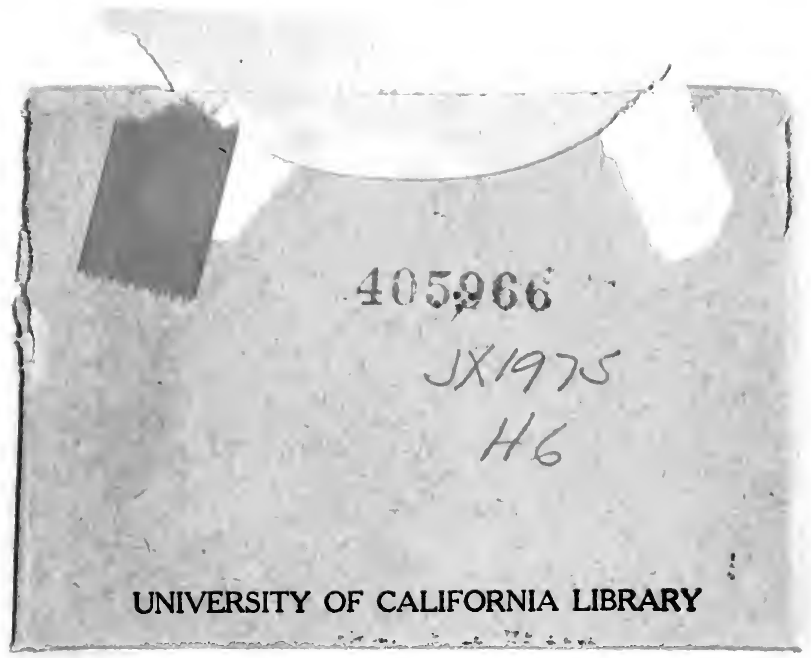


